\title{
III) Nordiskt samarbete
}

\section{Helsingforsavtalet}

Samarbetsöverenskommelse

\author{
mellan Danmark, Finland,
}

\section{Island, Norge och Sverige}

\footnotetext{
† Svenska

\# suomi

$\#$ Íslenska

$\Perp$ Norsk

+ Dansk

壯 English
} 


\section{Helsingforsavtalet}

\section{Samarbetsöverenskommelse mellan Danmark, Finland, Island, Norge och Sverige}

ANP 2018:717

ISBN 978-92-893-5364-9 (PRINT)

ISBN 978-92-893-5365-6 (PDF)

ISBN 978-92-893-5366-3 (EPUB)

http://dx.doi.org/10.6027/ANP2018-717

(c) Nordiska ministerrådet och Nordiska rådet

Layout: Louise Jeppesen

Tryck: Hillerød Grafisk

Printed in Denmark

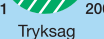

\section{Det nordiska samarbetet}

Det nordiska samarbetet är ett av världens mest omfattande regionala samarbeten. Det omfattar Danmark, Finland, Island, Norge och Sverige samt Färöarna, Grönland och Åland.

Det nordiska samarbetet är politiskt, ekonomiskt och kulturellt förankrat och en viktig del av europeiskt och internationellt samarbete. Den nordiska gemenskapen arbetar för ett starkt Norden i ett starkt Europa.

Det nordiska samarbetet vill styrka nordiska och regionala intressen och värderingar i en global omvärld. Gemensamma värderingar länderna emellan bidrar till att stärka Nordens ställning som en av världens mest innovativa och konkurrenskraftiga regioner.

\section{Nordiska ministerrådet \\ Nordens Hus \\ Ved Stranden 18 \\ DK-1061 Köpenhamn K \\ www.norden.org}

Ladda ner och beställ nordiska publikationer: www.norden.org/nordpub 


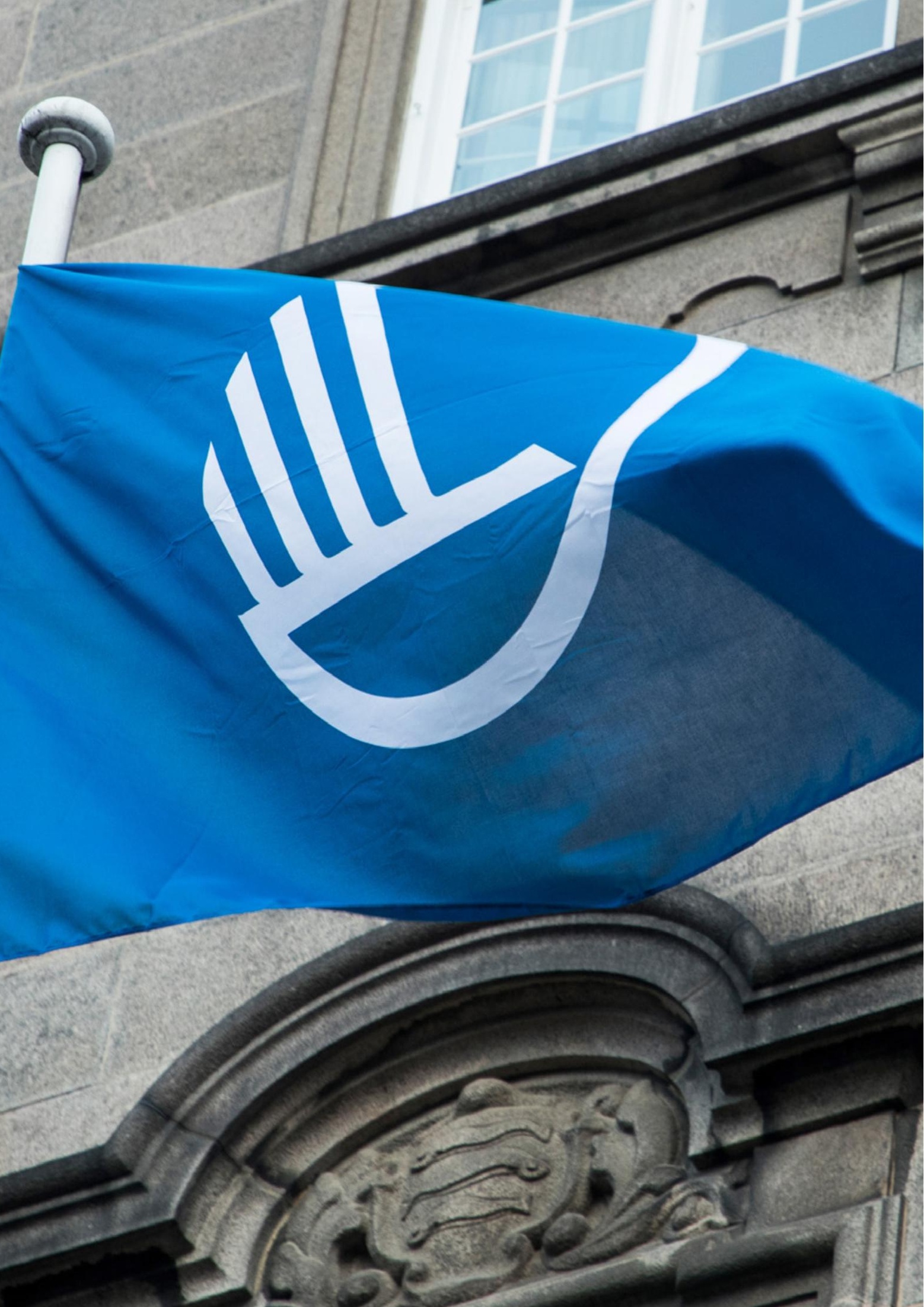





\section{Språkversioner}

Svenska

6

Suomi

18

Íslenska

30

Norsk

42

Dansk

54

English

66 


\section{Helsingforsavtalet}

Helsingforsavtalet - samarbetsöverenskommelse mellan Danmark, Finland, Island, Norge och Sverige.

Avtalet undertecknades den 23 mars 1962 och trädde i kraft den 1 juli samma år. Den ursprungliga texten har reviderats genom överenskommelser som undertecknats den 13 februari 1971, den 11 mars 1974, den 15 juni 1983, den 6 maj 1985, den 21 augusti 1991, den 18 mars 1993 och den 29 september 1995. De senaste ändringarna trädde i kraft den 2 januari 1996.

\section{Preambel till överenskommelsen den 23 mars 1962}

Danmarks, Finlands, Islands, Norges och Sveriges regeringar,

vilka vilja ytterligare främja den nära gemenskap, som i fråga om kultur samt om rätts- och samhällsuppfattning råder mellan de nordiska folken, och ytterligare utveckla samarbetet mellan de nordiska länderna;

vilka eftersträva enhetliga regler i de nordiska länderna i så många avseenden som möjligt;

vilka vilja på alla områden, där förutsättningar därför finnas, åstadkomma en ändamålsenlig arbetsfördelning mellan länderna;

vilka vilja fortsätta det för länderna betydelsefulla samarbetet inom Nordiska rådet och övriga samarbetsorgan;

ha enats om följande bestämmelser:

\section{Preambel till överenskommelsen} den 13 februari 1971

Danmarks, Finlands, Islands, Norges och

Sveriges regeringar,

vilka vilja stärka och ytterligare utbygga de institutionella grundvalarna för samarbetet mellan de nordiska länderna,

vilka finna det ändamålsenligt att i detta syfte ändra samarbetsöverenskommelsen den 23 mars 1962 mellan de nordiska länderna,

vilka därför ha beslutat att i samarbetsöverenskommelsen införa de grundläggande bestämmelserna om Nordiska rådet,

vilka tillika ha beslutat att i samarbetsöverenskommelsen införa bestämmelser om ett nordiskt ministerråd med behörighet för hela det nordiska samarbetsfältet, ha enats om följande:

\section{Preambel till överenskommelsen}

\section{den 11 mars 1974}

Danmarks, Finlands, Islands, Norges och

Sveriges regeringar,

vilka genom överenskommelsen den 13

februari 1971 ändrat samarbetsöverenskommelsen mellan de nordiska länderna den 23 mars 1962,

vilka finna det ändamålsenligt att göra vissa ytterligare ändringar i och tillägg till överenskommelsen, ha enats om följande:

\section{Preambel till överenskommelsen den 15 juni 1983} Danmarks, Finlands, Islands, Norges och Sveriges regeringar,

vilka genom överenskommelser av den 13 februari 1971 och den 11 mars 1974 ändrat 
samarbetsöverenskommelsen den 23 mars

1962 mellan de nordiska länderna,

vilka finner det ändamålsenligt att göra vissa ändringar i överenskommelsen för att ge Färöarna och Åland en utökad representation i Nordiska rådet och Nordiska ministerrådet samt för att ge Grönland samma representation i dessa organ,

har enats om följande:

\section{Preambel till överenskommelsen den 6 maj 1985}

Danmarks, Finlands, Islands, Norges och

Sveriges regeringar, som genom överenskommelser av den 13 februari 1971, den 11 mars 1974 och den 15 juni 1983 ändrat samarbetsöverenskommelsen den 23 mars 1962 mellan de nordiska länderna och som önskar effektivera det nordiska samarbetets arbetsformer, har kommit överens om följande:

\section{Preambel till överenskommelsen} den 21 augusti 1991

Danmarks, Finlands, Islands, Norges och

Sveriges regeringar, som genom överenskommelser den 13 februari 1971, den 11 mars 1974, den 15 juni 1983 och den 6 maj 1985 ändrat samarbetsöverenskommelsen den 23 mars 1962 mellan de nordiska länderna, och som finner det ändamålsenligt att göra vissa ändringar av Nordiska rådets organisation och arbetsformer, har kommit överens om följande:

\section{Preambel till överenskommelsen den 18 mars 1993}

Danmarks, Finlands, Islands, Norges och

Sveriges regeringar, som genom överenskommelser av den 13 februari 1971, den 11 mars 1974, den 15 juni 1983, den 6 maj 1985 och den 21 augusti 1991 har ändrat samarbetsöverenskommel- sen av den 23 mars 1962 mellan de nordiska länderna, och

som önskar förnya och utveckla det nordiska samarbetet i ljuset av de nordiska ländernas utvidgade deltagande i europeiskt samarbete,

har kommit överens om följande:

\section{Preambel till överenskommelsen den 29 september 1995}

Danmarks, Finlands, Islands, Norges och

Sveriges regeringar,

som genom överenskommelser den 13 februari 1971, den 11 mars 1974, den 15 juni 1983, den 6 maj 1985, den 21 augusti 1991 och den 18 mars 1993 ändrat samarbetsöverenskommelsen av den 23 mars 1962 mellan de nordiska länderna, och

som önskar ytterligare förnya och utveckla det nordiska samarbetet i ljuset av de nordiska ländernas utvidgade deltagande i europeiskt samarbete,

har kommit överens om följande:

\section{Inledande bestämmelse}

\section{Artikel $1(1,8)$}

De fördragsslutande parterna skall eftersträva att bevara och ytterligare utveckla samarbetet mellan länderna på det rättsliga, kulturella, sociala och ekonomiska området samt i fråga om samfärdseln och miljövården.

De fördragsslutande parterna bör rådgöra med varandra i frågor av gemensamt intresse som behandlas i europeiska och andra internationella organisationer och konferenser.

\section{Rättsligt samarbete}

\section{Artikel 2 (9)}

Vid utformningen av lagar och andra rättsregler i de nordiska länderna skall medborgare i de övriga länderna behandlas lika med landets egna medborgare. Det gäller inom samarbetsöverenskommelsens tillämpningsområde. 
Undantag från första stycket kan dock göras, om krav på medborgarskap är grundlagsfäst, nödvändigt på grund av andra internationella åtaganden eller det i övrigt av särskilda skäl bedöms nödvändigt.

\section{Artikel 3}

De fördragsslutande parterna skola söka underlätta för medborgare i ett nordiskt land att förvärva medborgarskap i annat nordiskt land.

\section{Artikel 4}

De fördragsslutande parterna skola fortsätta lagsamarbetet i syfte att uppnå största möjliga överensstämmelse på privaträttens område.

\section{Artikel 5}

De fördragsslutande parterna bör eftersträva enhetliga bestämmelser om brott och brottspåföljder.

Beträffande brott, som begåtts i ett nordiskt land, bör utredning och lagföring $\mathrm{i}$ största möjliga utsträckning kunna ske även i annat nordiskt land.

\section{Artikel 6}

De fördragsslutande parterna skola eftersträva inbördes samordning av annan lagstiftning än som nu sagts på sådana områden, där detta ter sig ändamålsenligt.

\section{Artikel 7}

Varje fördragsslutande part böra verka för genomförandet av sådana regler, att beslut av domstol eller annan myndighet i annat nordiskt land kan verkställas jämväl inom partens område.

\section{Kulturellt samarbete}

\section{Artikel 8 (2)}

Undervisningen och utbildningen skall i skolorna i de nordiska länderna i lämplig omfattning innefatta undervisning om språk, kultur och allmänna samhällsförhållanden i de övriga nordiska länderna, inbegripet Färöarna, Grönland och Åland.

\section{Artikel 9}

Varje fördragsslutande part bör bibehålla och vidga möjligheten för studerande, hemmahörande i annat nordiskt land, att idka studier och avlägga examen vid sina utbildningsanstalter. I största möjliga utsträckning bör därvid även i något nordiskt land avlagd delexamen få räknas till godo för slutexamen $\mathrm{i}$ annat nordiskt land.

Ekonomiskt stöd från hemlandet bör kunna utgå, oavsett till vilket land studierna förläggas.

\section{Artikel 10}

De fördragsslutande parterna bör samordna sådan av det allmänna ordnad utbildning, som syftar till att giva behörighet för viss yrkesutövning.

Sådan utbildning bör såvitt möjligt giva samma behörighet i alla de nordiska länderna. Krav må dock uppställas på sådan tilläggsutbildning, som kan erfordras av hänsyn till nationella förhållanden.

\section{Artikel 11}

På de områden där ett samarbete är ändamålsenligt bör utbyggnaden av utbildningsanstalter samordnas genom fortlöpande samverkan beträffande utbyggnadsplaneringen och dess genomförande.

\section{Artikel 12}

Samarbete på forskningens område bör vara så inriktat att tillgängliga forskningsanslag och övriga resurser samordnas och utnyttjas på bästa möjliga sätt, bland annat genom att gemensamma institutioner upprättas.

\section{Artikel 13}

I syfte att stödja och stärka den kulturella 
utvecklingen skola de kontraherande

parterna främja det fria nordiska folkbildningsarbetet och utbytet inom litteratur, konst, musik, teater, film och övriga kulturområden, varvid böra tillvaratagas bland annat de möjligheter som radio och television erbjuda.

\section{Socialt samarbete}

\section{Artikel 14}

De fördragsslutande parterna skola eftersträva att bevara och ytterligare utveckla den gemensamma nordiska arbetsmarknaden efter de riktlinjer, som uppdragits genom tidigare överenskommelser. Arbetsförmedling och yrkesvägledning skola samordnas. Utbytet av praktikanter skall vara fritt.

Likformighet beträffande nationella regler rörande arbetarskydd och liknande frågor bör eftersträvas.

\section{Artikel 15}

De fördragsslutande parterna skola verka för att medborgare i ett nordiskt land vid vistelse i annat nordiskt land skall i största möjliga utsträckning komma i åtnjutande av de sociala förmåner, som må utgå i vistelselandet till dess egna medborgare.

\section{Artikel 16}

De fördragsslutande parterna skola ytterligare utveckla samarbetet beträffande hälsooch sjukvård, nykterhetsvård samt vård av barn och ungdom.

\section{Artikel 17}

Varje fördragsslutande part skall verka för att medicinsk, teknisk eller annan liknande säkerhetskontroll utföres på sådant sätt att attest eller intyg om kontrollen kan godtagas $i$ övriga nordiska länder.

\section{Ekonomiskt samarbete}

\section{Artikel 18}

De fördragsslutande parterna skola, i avsikt att främja det nordiska ekonomiska samarbetet på olika områden, samråda i fråga om den ekonomiska politiken. Därvid bör uppmärksamhet ägnas möjligheterna att samordna åtgärder, som vidtagas i konjunkturutjämnande syfte.

\section{Artikel 19}

De fördragsslutande parterna avse att så långt det är möjligt främja produktions- och investeringssamarbete mellan sina länder och att härvid söka lägga förhållandena till rätta för direkt samarbete mellan företag i två eller flera av de nordiska länderna. De fördragsslutande parterna böra som ett led i ett vidare internationellt samarbete eftersträva att uppnå en ändamålsenlig arbetsfördelning mellan länderna i fråga om produktion och investeringar.

\section{Artikel 20}

De fördragsslutande parterna skola verka för största möjliga frihet för kapitalrörelser mellan de nordiska länderna. Beträffande andra betalnings- och valutafrågor av samfällt intresse skola gemensamma lösningar eftersträvas.

\section{Artikel 21}

De fördragsslutande parterna skola eftersträva att befästa det samarbete, som tidigare inletts i syfte att undanröja hinder för handeln mellan de nordiska länderna, samt att så långt möjligt ytterligare stärka och utveckla detta samarbete.

\section{Artikel 22}

De fördragsslutande parterna skola i internationella handelspolitiska frågor såväl var för sig som gemensamt söka främja nordis- 
ka intressen och i detta syfte rådgöra med varandra.

\section{Artikel 23}

De fördragsslutande parterna skola verka för samordning av de tulltekniska och tulladministrativa bestämmelserna samt för sådana förenklingar i tullhänseende som äro ägnade att underlätta samfärdseln mellan länderna.

\section{Artikel 24}

Bestämmelserna för den nordiska gränshandeln skola utformas på sådant sätt, att gränstrakternas invånare åsamkas minsta möjliga olägenheter.

\section{Artikel 25}

När behov och förutsättningar föreligga för gemensam ekonomisk utbyggnad av sådana områden inom två eller flera fördragsslutande parters territorier som gränsa till varandra, skola dessa parter tillsammans söka främja en sådan utbyggnad.

\section{Samarbete på samfärdselns område}

\section{Artikel 26}

De fördragsslutande parterna skola eftersträva att befästa det samarbete som tidigare inletts på samfärdselns område samt söka utveckla detta samarbete i syfte att underlätta förbindelserna och varuutbytet mellan länderna och erhålla en ändamålsenlig lösning av de problem, som må förefinnas på detta område.

\section{Artikel 27}

Byggandet av samfärdselled, som berör två eller flera fördragsslutande parters områden, skall ske i samråd mellan de berörda parterna.

\section{Artikel 28}

De fördragsslutande parterna skola söka bevara och ytterligare utveckla det samarbete som lett till att deras territorier utgöra ett passkontrollområde. Kontrollen av resande, som passera gräns mellan nordiska länder, skall även i övrigt förenklas och samordnas.

\section{Artikel 29}

De fördragsslutande parterna skola samordna arbetet för ökad trafiksäkerhet.

\section{Samarbete på miljövårdens område (3)}

\section{Artikel 30 (3)}

De fördragsslutande parterna skola i nationell lagstiftning och vid tillämpningen därav i största möjliga omfattning likställa övriga fördragsslutande parters miljövårdsintressen med det egna landets.

\section{Artikel 31 (3)}

De fördragsslutande parterna skola eftersträva harmonisering av sina miljöskyddsregler i syfte att uppnå största möjliga överensstämmelse i fråga om normer och riktlinjer för utsläpp av föroreningar, användning av miljögifter och andra störningar av miljön.

\section{Artikel 32 (3)}

De fördragsslutande parterna skola eftersträva samordning i fråga om avsättning av naturskydds- och friluftsområden samt i fråga om fridlysning och andra åtgärder för skydd av växter och djur.

\section{Samarbete i övrigt}

\section{Artikel 33 (8)}

De fördragsslutande parternas deltagande i europeiskt och annat internationellt samarbete ger goda möjligheter för samarbete till förmån för nordiska medborgare och företag. Det åligger i detta sammanhang regeringarna ett särskilt ansvar för att tillvarata gemensamma intressen och värderingar.

\section{Artikel 34}

Befattningshavare, som tillhör en fördragsslutande parts utrikestjänst och tjänstgör utan- 
för de nordiska länderna, skall i den mån det

är förenligt med hans tjänsteåligganden samt hinder icke möter från tjänstgöringslandets sida bistå jämväl medborgare i annat nordiskt land, därest detta saknar representation på den ifrågavarande orten.

\section{Artikel 35}

De fördragsslutande parterna böra, närhelst det befinnes möjligt och ändamålsenligt, samordna sin verksamhet för bistånd till och samarbete med utvecklingsländerna.

\section{Artikel 36}

Åtgärder i syfte att sprida ökad kännedom om de nordiska länderna och det nordiska samarbetet böra vidtagas i nära samverkan mellan de fördragsslutande parterna och deras organ för utlandsupplysning. Där så befinnes lämpligt kunna samfällda framträdanden komma i fråga.

\section{Artikel 37}

De fördragsslutande parterna skola verka för att olika grenar av den offentliga statistiken samordnas.

\section{Särskilda överenskommelser (3)}

\section{Artikel 38 (3)}

Närmare bestämmelser om samarbetet inom nu angivna områden kunna meddelas i särskilda överenskommelser.

\section{Formerna för nordiskt samarbete}

\section{Artikel 39 (4)}

För att genomföra och vidareutveckla det nordiska samarbetet enligt denna och andra överenskommelser böra de nordiska länderna fortlöpande samråda och vid behov vidtaga samordnande åtgärder.
Artikel $\mathbf{4 0}(4,8)$

Samarbetet äger rum inom Nordiska rådet, inom Nordiska ministerrådet, på statsministrarnas, på utrikesministrarnas samt på andra ministrars möten, i särskilda samarbetsorgan och mellan ländernas fackmyndigheter.

\section{Artikel 41}

Bestämmelse som tillkommit efter samarbete mellan två eller flera fördragsslutande parter må ej av part ändras, med mindre övriga parter därom underrättas. Underrättelse erfordras dock icke i brådskande fall eller då fråga är om bestämmelse av mindre betydelse.

\section{Artikel 42}

Myndigheter i de nordiska länderna äga skriftväxla direkt med varandra i andra ärenden än sådana som till följd av sin natur eller av annat skäl böra handläggas genom förmedling av utrikesförvaltningen.

\section{Artikel 43 (3)}

I det nordiska samarbetet bör största möjliga offentlighet iakttagas.

\section{Nordiska rådet (5)}

Artikel $44(5,2)$

I Nordiska rådet samarbeta de nordiska ländernas samt Färöarnas, Grönlands och Ålands folkrepresentationer, ländernas regeringar samt Färöarnas och Grönlands landsstyren och Ålands landskapsstyrelse. Rådet är initiativtagande och rådgivande i frågor, som avse samverkan mellan alla eller några av dessa länder och Färöarna, Grönland och Åland, samt har i övrigt de uppgifter som framgå av denna och andra överenskommelser.

\section{Artikel 45 (5)}

Rådet kan antaga rekommendation, göra annan framställning eller avgiva yttrande till en eller flera av de nordiska ländernas regeringar eller till ministerrådet. 


\section{Artikel 46 (5)}

Rådet bör, utöver vad som särskilt överenskommits, beredas tillfälle att yttra sig om nordiska samarbetsfrågor av större betydelse när detta icke är ogörligt av tidsskäl.

\section{Artikel $47(5,2,8)$}

Rådet består av 87 valda medlemmar, regeringsrepresentanter och representanter för Färöarnas och Grönlands landsstyren och Ålands landskapsstyrelse.

Av medlemmarna väljer Danmarks folketing sexton, Finlands riksdag aderton, Islands allting sju, Norges storting och Sveriges riksdag vardera tjugo samt ett vart av Färöarnas lagting, Grönlands landsting och Ålands lagting två. Dessutom väljer varje församling motsvarande antal suppleanter.

Val av medlemmar och suppleanter förrättas årligen och gäller för tiden till nästa val. Vid val skall olika politiska meningsriktningar ges representation i rådet.

Endast den som är medlem av den församling som förrättat valet kan vara vald medlem eller suppleant i rådet.

Regeringarna, landsstyrena och landskapsstyrelsen utser bland sina medlemmar det antal representanter som de önskar.

\section{Artikel $48(5,2,8,9)$}

Danmarks rikes delegation består av de av folketinget valda medlemmarna och de av regeringen utsedda representanterna samt av Färöarnas och Grönlands i andra stycket nämnda delegationer. Finlands delegation består av de av riksdagen valda medlemmarna och de av regeringen utsedda representanterna samt av Ålands i andra stycket nämnda delegation. För ettvart av de övriga länderna består delegationen av de av folkrepresentationen valda medlemmarna och de av regeringen utsedda representanterna.

Färöarnas delegation består av de av lagtinget valda medlemmarna och de av landsstyret utsedda representanterna. Grönlands delegation består av de av landstinget valda medlemmarna och de av landsstyret utsedda representanterna. Ålands delegation består av de av lagtinget valda medlemmarna och de av landskapsstyrelsen utsedda representanterna.

Med "delegation" förstås i artikel 58, andra stycket, landets delegation.

\section{Artikel $49(5,2)$}

Regeringsrepresentanterna samt landsstyrenas och landskapsstyrelsens representanter ha icke rösträtt i rådet.

I frågor, som angå tillämpningen av överenskommelser mellan vissa länder, ha endast medlemmar från dessa länder rösträtt.

\section{Artikel $\mathbf{5 0}$ (5)}

Rådets organ äro plenarförsamlingen, presidiet och utskotten.

\section{Artikel $\mathbf{5 1}(5,7,9)$}

Plenarförsamlingen utgöres av alla medlemmar av rådet.

Plenarförsamlingen håller ordinarie session minst en gång om året. Extra session eller temasession hålles när presidiet så beslutar eller när minst två regeringar eller minst tjugofem valda medlemmar begär det.

Rådets befogenheter utövas av plenarförsamlingen, om icke annat är särskilt föreskrivet.

Plenarförsamlingens förhandlingar är offentliga, om plenarförsamlingen icke beslutar annat.

Artikel $\mathbf{5 2}(5,6,7,9)$

Plenarförsamlingen utser för ett kalenderår vid årlig ordinarie session ett presidium bestående av en president och det antal medlemmar som anges $i$ arbetsordningen för Nordiska rådet.

Olika politiska meningsriktningar skall vara företrädda i presidiet. Varje land skall vara representerat i presidiet. 
Medlem av presidiet skall vara vald medlem av rådet.

Presidiet handhar rådets löpande angelägenheter och företräder i övrigt rådet i den utsträckning som framgår av denna överenskommelse och rådets arbetsordning.

Presidentskapet i rådet roterar mellan de nordiska länderna på det sätt som framgår av arbetsordningen för Nordiska rådet.

Artikel $53(5,9)$

Plenarförsamlingen bestämmer utskottens antal och verksamhetsområden. Utskotten har till uppgift att förbereda sakernas behandling i rådet.

Artikel 54 (5,6,7,9)

Rådet bistås i sin verksamhet av ett presidiesekretariat.

Artikel $\mathbf{5 5}(5,2,7,9)$

Regeringarna, Färöarnas landsstyre, Grönlands landsstyre, Ålands landskapsstyrelse, ministerrådet, rådets presidium och utskotten samt medlem har rätt att väcka förslag i rådet.

Artikel $56(5,7)$

Rekommendation antages av plenarförsamlingen på grundval av väckt förslag.

Annan framställning kan göras av presidiet på grundval av väckt förslag.

Yttrande avgives av plenarförsamlingen. När presidiet gör framställning avgives yttrande av presidiet.

Presidiet skall till plenarförsamlingen anmäla de åtgärder det vidtagit med stöd av andra eller tredje stycket.

\section{Artikel $\mathbf{5 7}(5,7)$}

Vald medlem får ställa fråga till regering eller till ministerrådet med anledning av berättelse eller meddelande som avgivits till rådet eller i övrigt i ämne som angår det nordiska samarbetet.
Artikel $58(5,2,7)$

Varje delegation svarar för utgifterna för sitt deltagande i rådet.

Presidiet fattar för varje budgetår beslut om hur de gemensamma utgifterna skall fördelas mellan delegationerna.

\section{Artikel $\mathbf{5 9}$ (5)}

Plenarförsamlingen fastställer rådets arbetsordning. För beslut om antagande av arbetsordning eller om ändring i denna erfordras två tredjedels flertal bland rådets valda medlemmar.

\section{Nordiska ministerrådet (5)}

\section{Artikel $60(5,2)$}

I Nordiska ministerrådet samarbeta de nordiska ländernas regeringar.

Färöarnas och Grönlands landsstyren samt Ålands landskapsstyrelse deltaga i ministerrådets arbete.

Ministerrådet fattar beslut i den utsträckning som angives i denna och andra överenskommelser mellan de nordiska länderna.

Även i övriga samarbetsfrågor svarar ministerrådet för samarbetet mellan de nordiska ländernas regeringar och mellan regeringarna och Nordiska rådet.

Artikel $61(5,1,2,8)$

Medlem av regering, landsstyre eller landskapsstyrelse kan i undantagsfall vid sammanträde företrädas av härtill befullmäktigad; dock måste minst tre av länderna vara representerade av regeringsmedlemmar.

Statsministrarna har ansvaret för den överordnade samordningen av nordiska samarbetsfrågor. De biträds av en utsedd regeringsmedlem i varje land (samarbetsminister) och en statssekreterare eller ämbetsman (ledamot $i$ den nordiska samarbetskommittén).

Ordförandeskapet roterar mellan de nordiska ländernas regeringar enligt närmare avtal. Ordförandeskapet har ansvaret för att 
samordna nordiskt regeringssamarbete och ta nödvändiga initiativ. Ordförandeskapet leder arbetet i ministerrådet, på andra ministermöten och vid regeringarnas samråd om europeiska och andra internationella frågor på alla nivåer.

Ministerrådet bistås i sin verksamhet av ämbetsmannakommittéer och av ministerrådets sekretariat.

\section{Artikel 62 (5)}

Ministerrådet är beslutfört då alla länderna äro företrädda i ministerrådet. I frågor, som uteslutande angå vissa länder, behöva dock endast dessa länder vara företrädda.

Varje land har en röst i ministerrådet.

Ministerrådets beslut skola vara enhälliga. I procedurfrågor fattas dock beslut med enkelt flertal bland de röstande och vid lika röstetal med ordförandens utslagsröst.

Nedlagd röst utgör icke hinder för beslut.

\section{Artikel $63(5,2,8)$}

Beslut av ministerrådet är bindande för de särskilda länderna. Beslut i fråga som enligt något lands författning kräver folkrepresentationens godkännande binder dock icke detta land förrän folkrepresentationen godkänt beslutet. Erfordras sådant godkännande, skall ministerrådet underrättas härom innan ministerrådet fattar beslutet. Innan folkrepresentationens godkännande givits, är ej heller annat land bundet av beslutet.

Beslut fattat i överensstämmelse med denna överenskommelse är bindande för Färöarna, Grönland och Åland i den mån de ansluter sig till beslutet i enlighet med självstyrelseordningarna.

\section{Artikel $64(5,6,8)$}

Ministerrådet skall till Nordiska rådet årligen framlägga en berättelse rörande det nordiska samarbetet och en redogörelse för planerna för det fortsatta samarbetet.
Ordförandelandets statsminister redogör för Nordiska rådet om huvuddragen i samarbetet och om regeringarnas samarbete rörande europeiska och andra internationella frågor.

Nordiska ministerrådet skall lägga fram sitt förslag till budget för Nordiska rådet för yttrande.

Nordiska rådet kan föreslå förändrade prioriteringar inom den av ministerrådet angivna finansiella ramen.

Om inte synnerliga skäl kan anföras skall ministerrådet följa rådets rekommendation när det gäller budgetdispositioner inom den angivna finansiella ramen.

\section{Artikel 65 (5)}

Ministerrådet skall före varje ordinarie session med Nordiska rådets plenarförsamling lämna rådet meddelande om de åtgärder som ha vidtagits med anledning av rådets rekommendationer och andra framställningar. Har rekommendation eller annan framställning riktats till en eller flera regeringar, kan sådant meddelande i stället lämnas av den eller de regeringar, till vilka rekommendationen eller framställningen har riktats.

\section{Artikel 66 (5)}

Ministerrådet fastställer sin arbetsordning.

\section{Artikel 67 (5)}

Samråd mellan de nordiska ländernas regeringar kan förutom i ministerrådet ske vid nordiska ministermöten.

\section{Ändring av överenskommelsen (5)}

\section{Artikel 68 (5)}

Innan länderna överenskomma om ändring $\mathrm{i}$ denna överenskommelse, skall Nordiska rådet beredas tillfälle att yttra sig. 


\section{Slutstadganden}

Slutbestämmelser till överenskommelsen den 23 mars 1962

\section{Artikel 69}

Denna överenskommelse skall ratificeras och ratifikationshandlingarna skola snarast möjligt deponeras i ministeriet för utrikesärendena i Finland.

Överenskommelsen träder i kraft första dagen i den månad, som infaller närmast efter den dag då samtliga parters ratifikationshandlingar deponerats.

\section{Artikel 70}

Önskar någon av de fördragsslutande parterna uppsäga överenskommelsen skall skriftligt meddelande härom tillställas den finska regeringen, som har att omedelbart underrätta övriga fördragsslutande parter härom och om dagen då meddelandet mottogs.

Uppsägningen gäller endast det land, som verkställt densamma, och äger giltighet från och med första dagen i den månad som inträffar sex månader från det den finska regeringen mottagit meddelande om uppsägningen.

Överenskommelsen skall vara deponerad $\mathrm{i}$ ministeriet för utrikesärendena i Finland och bestyrkta avskrifter skola av det finska ministeriet tillställas var och en av de fördragsslutande parterna.

Till bekräftelse härav hava undertecknade befullmäktigade ombud undertecknat denna överenskommelse.

Som skedde i Helsingfors i ett exemplar på danska, finska, isländska, norska och svenska språken, vilka samtliga texter äga lika vitsord, den tjugotredje mars nittonhundrasextiotvå. [...]
Slutbestämmelser till överenskommelsen den 13 februari 1971

Denna överenskommelse skall ratificeras och ratifikationshandlingarna snarast möjligt deponeras i ministeriet för utrikesärendena i Finland.

Överenskommelsen skall vara deponerad i ministeriet för utrikesärendena i Finland och bestyrkta avskrifter skola av det finska ministeriet tillställas var och en av de fördragsslutande parterna.

Överenskommelsen träder i kraft trettio dagar efter den dag då samtliga fördragsslutande parters ratifikationshandlingar deponerats.

Till bekräftelse härav ha undertecknade befullmäktigade ombud i Köpenhamn den 13 februari 1971 undertecknat denna överenskommelse i ett exemplar på danska, finska, isländska, norska och svenska språken, vilka samtliga texter ha lika vitsord.

$[\ldots]$

Slutbestämmelser till överenskommelsen den 11 mars 1974

Denna överenskommelse skall ratificeras och ratifikationshandlingarna snarast möjligt deponeras i ministeriet för utrikesärendena i Finland.

Överenskommelsen skall vara deponerad i ministeriet för utrikesärendena i Finland och bestyrkta avskrifter skola av det finska ministeriet tillställas var och en av de fördragsslutande parterna.

Överenskommelsen träder i kraft trettio dagar efter den dag då samtliga fördragsslutande parters ratifikationshandlingar deponerats.

Till bekräftelse härav ha undertecknade befullmäktigade ombud i Köpenhamn den 11 mars 1974 undertecknat denna överenskommelse i ett exemplar på danska, finska, isländska, norska och svenska språken, vilka samtliga texter ha lika vitsord.

[...] 
Slutbestämmelser till överenskommelsen den 15 juni 1983

Denna överenskommelse skall ratificeras och ratifikationshandlingarna snarast möjligt deponeras i Finlands ministerium för utrikesärendena som skall överlämna bestyrkta kopior av överenskommelsen till de övriga fördragsslutande parterna.

Överenskommelsen träder i kraft trettio dagar efter den dag då samtliga fördragsslutande parters ratifikationshandlingar deponerats.

Till bekräftelse härav har undertecknade befullmäktigade ombud i Reykjavik den 15 juni 1983 undertecknat denna överenskommelse i ett exemplar på danska, finska, isländska, norska och svenska språken, vilka samtliga texter äger samma vitsord.

[...]

\section{Slutbestämmelser till överenskommelsen} den 6 maj 1985

Överenskommelsen träder i kraft trettio dagar efter den dag då samtliga fördragsslutande parter har meddelat Finlands utrikesministerium, att de åtgärder som krävs för överenskommelsens ikraftträdande har vidtagits.

Finlands utrikesministerium meddelar de övriga fördragsslutande parterna om tidpunkten för mottagandet av dessa meddelanden.

Originalexemplaret till denna överenskommelse deponeras hos Finlands utrikesministerium, som tillställer de övriga fördragsslutande parterna bestyrkta kopior därav.

Till bekräftelse härav har de vederbörligen befullmäktigade ombuden undertecknat denna överenskommelse.

Som skedde i Lund den 6 maj 1985 i ett exemplar på danska, finska, isländska, norska och svenska språken, vilka samtliga texter äger lika vitsord.

$[\ldots]$
Slutbestämmelser till överenskommelsen den 21 augusti 1991

Överenskommelsen träder i kraft trettio dagar efter den dag då samtliga parter har meddelat det finska utrikesministeriet att överenskommelsen godkänts.

Det finska utrikesministeriet meddelar de övriga parterna om mottagandet av dessa meddelanden och om tidpunkten för överenskommelsens ikraftträdande.

Originalexemplaret till denna överenskommelse deponeras hos det finska utrikesministeriet, som tillställer de övriga parterna bestyrkta kopior därav.

Till bekräftelse härav har de vederbörligen befullmäktigade ombuden undertecknat denna överenskommelse.

Som skedde i Tammerfors den 21 augusti 1991 i ett exemplar på danska, finska, isländska, norska och svenska språken, vilka samtliga texter äger lika giltighet.

[...]

Slutbestämmelser till överenskommelsen den 18 mars 1993

Överenskommelsen träder i kraft trettio dagar efter den dag då samtliga fördragsslutande parter har meddelat Finlands utrikesministerium, att överenskommelsen har godkänts.

Finlands utrikesministerium meddelar de övriga fördragsslutande parterna om mottagandet av dessa meddelanden och om tidpunkten för överenskommelsens ikraftträdande.

Originalexemplaret till denna överenskommelse deponeras hos Finlands utrikesministerium, som tillställer de övriga fördragsslutande parterna bestyrkta kopior därav.

Till bekräftelse härav har de vederbörligen befullmäktigade ombuden undertecknat denna överenskommelse.

Som skedde i Helsingfors den 18 mars 1993 i ett exemplar på danska, finska, isländska, norska och svenska språken, vilka samtliga texter har samma giltighet.

[...] 
Slutbestämmelser till överenskommelsen

den 29 september 1995

Överenskommelsen träder i kraft femton dagar efter den dag då samtliga parter meddelat det finska utrikesministeriet att överenskommelsen godkänts.

Det finska utrikesministeriet meddelar de övriga parterna om mottagandet av dessa meddelanden och om tidpunkten för överenskommelsens ikraftträdande.

Originalexemplaret till denna överenskommelse deponeras hos det finska utrikesministeriet, som tillställer de övriga parterna bestyrkta kopior därav.

Till bekräftelse härav har de vederbörligen befullmäktigade ombuden undertecknat denna överenskommelse.

Som skedde i Köpenhamn den 29 september 1995 i ett exemplar på danska, finska, isländska, norska och svenska språken, vilka samtliga texter äger lika giltighet.

[...]

\section{Noter}

1 Ny lydelse 1974.

2 Ny lydelse 1983.

3 Artikeln tillkom 1974.

4 Ny lydelse 1971.

5 Artikeln tillkom 1971.

6 Ny lydelse 1985.

7 Ny lydelse 1991.

8 Ny lydelse 1993.

9 Ny lydelse 1995. 


\section{Helsingin sopimus}

Yhteistyösopimus Islannin, Norjan, Ruotsin, Suomen ja Tanskan välillä

(Helsingin sopimus).

Sopimus allekirjoitettiin maaliskuun 23. päivänä 1962 ja tuli voimaan 1. päivänä heinäkuuta samana vuonna. Alkuperäistä tekstiö on muutettu sopimuksilla, jotka on allekirjoitettu helmikuun 13. päivänä 1971, maaliskuun 11. päivänä 1974, kesäkuun 15. päivänä 1983, toukokuun 6. päivänä 1985, elokuun 21. päivänä 1991, maaliskuun 18. päivänä 1993 ja syyskuun 29. päivänä 1995. Viimeisimmät muutokset astuivat voimaan tammikuun 2. päivänä 1996.

Maaliskuun 23. päivänä 1962 allekirjoitetun sopimuksen johtolause Islannin, Norjan, Ruotsin, Suomen ja Tanskan hallitukset,

jotka haluavat edelleen edistää Pohjoismaiden kansojen kesken kulttuurin sekä oikeus- ja yhteiskuntakäsitysten alalla vallitsevaa läheistä yhteisyyttä ja edelleen kehittää Pohjoismaiden välistä yhteistyötä;

jotka pyrkivät aikaansaamaan yhtenäisiä säännöksiä Pohjoismaissa mahdollisimman monilla aloilla;

jotka tahtovat kaikilla aloilla, missä siihen on edellytyksiä, aikaansaada tarkoituksenmukaisen työnjaon näiden maiden välillä;

jotka haluavat jatkaa näille maille tärkeätä yhteistyötä Pohjoismaiden neuvostossa ja muissa yhteistyöelimissä;

ovat sopineet seuraavista määräyksistä.
Helmikuun 13. päivänä 1971 allekirjoitetun sopimuksen johtolause Islannin, Norjan, Ruotsin, Suomen ja Tanskan hallitukset,

jotka haluavat lujittaa ja edelleen kehittää Pohjoismaiden välisen yhteistyön institutionaalisia perusteita,

joiden mielestä on tarkoituksenmukaista tämän tavoitteen saavuttamiseksi muuttaa Pohjoismaiden välillä 23 päivänä maaliskuuta 1962 tehtyä yhteistyösopimusta,

jotka tämän vuoksi ovat päättäneet sisällyttää yhteistyösopimukseen Pohjoismaiden neuvostoa koskevat perussäännökset,

jotka samalla ovat päättäneet sisällyttää yhteistyösopimukseen koko pohjoismaisen yhteistyön alveella toimivaltaista Pohjoismaiden ministerineuvostoa koskevat säännökset, ovat sopineet seuraavaa.

\section{Maaliskuun 11. päivänä 1974} allekirjoitetun sopimuksen johtolause Islannin, Norjan, Ruotsin, Suomen ja Tanskan hallitukset,

jotka ovat muuttaneet Pohjoismaiden välillä 23 päivänä maaliskuuta 1962 tehtyä yhteistyösopimusta sopimuksella 13 päivänä helmikuuta 1971,

joiden mielestä on tarkoituksenmukaista tehdä eräitä muita muutoksia ja lisäyksiä sopimukseen, ovat sopineet seuraavaa:

\section{Kesäkuun 15. päivänä 1983} allekirjoitetun sopimuksen johtolause Islannin, Norjan, Ruotsin, Suomen ja Tanskan hallitukset,

jotka ovat 13 päivänä helmikuuta 1971 ja 11 päivänä maaliskuuta 1974 tehdyillä sopi- 
muksilla muuttaneet Pohjoismaiden välillä 23 päivänä maaliskuuta 1962 tehtyä yhteistyösopimusta,

jotka pitävät tarkoituksenmukaisena tehdä sopimukseen tiettyjä muutoksia antaakseen Färsaarille ja Ahvenanmaalle laajemman edustuksen Pohjoismaiden neuvostossa ja Pohjoismaiden ministerineuvostossa sekä antaakseen Grönlannille vastaavan edustuksen näissä elimissä,

ovat sopineet seuraavasta:

\section{Toukokuun 6. päivänä 1985}

\section{allekirjoitetun sopimuksen johtolause}

Islannin, Norjan, Ruotsin, Suomen ja Tanskan

hallitukset,

jotka ovat 13 päivänä helmikuuta 1971, 11 päivänä maaliskuuta 1974 ja 15 päivänä kesäkuuta 1983 tehdyillä sopimuksilla muuttaneet Pohjoismaiden välillä 23 päivänä maaliskuuta 1962 tehtyä yhteistyösopimusta ja jotka haluavat tehostaa pohjoismaisen yhteistyön työmuotoja, ovat sopineet seuraavasta:

\section{Elokuun 21. päivänä 1991 allekirjoitetun sopimuksen johtolause}

Tanskan, Suomen, Islannin, Norjan ja Ruotsin hallitukset,

jotka ovat 13 päivänä helmikuuta 1971 , 11 päivänä maaliskuuta 1974, 15 päivänä kesäkuuta 1983 ja 6 päivänä toukokuuta 1985 tehdyillä sopimuksilla muuttaneet Pohjoismaiden välillä 23 päivänä maaliskuuta 1962 tehtyä yhteistyösopimusta, ja jotka pitävät tarkoituksenmukaisena tehdä tiettyjä muutoksia Pohjoismaiden neuvoston organisaatioon ja työmuotoihin, ovat sopineet seuraavasta:

\section{Maaliskuun 18. päivänä 1993} allekirjoitetun sopimuksen johtolause Tanskan, Suomen, Islannin, Norjan ja Ruotsin hallitukset, jotka ovat 13 päivänä helmikuuta 1971,
11 päivänä maaliskuuta 1974, 15 päivänä kesäkuuta 1983, 6 päivänä toukokuuta 1985 ja 21 päivänä elokuuta 1991 tehdyillä sopimuksilla muuttaneet Pohjoismaiden välillä 23 päivänä maaliskuuta 1962 tehtyä yhteistyösopimusta, ja

jotka haluavat uudistaa ja kehittää pohjoismaista yhteistyötä Pohjoismaiden Euroopan yhteistyöhön osallistumisen laajenemisen valossa,

ovat sopineet seuraavasta:

\section{Syyskuun 29. päivänä 1995}

allekirjoitetun sopimuksen johtolause

Tanskan, Suomen, Islannin, Norjan ja Ruotsin hallitukset,

jotka ovat 13 päivänä helmikuuta 1971, 11 päivänä maaliskuuta 1974, 15 päivänä kesäkuuta 1983, 6 päivänä toukokuuta 1985, 21 päivänä elokuuta 1991 ja 18 päivänä maaliskuuta 1993 tehdyillä sopimuksilla muuttaneet Pohjoismaiden välillä 23 päivänä maaliskuuta 1962 tehtyä yhteistyösopimusta, ja

jotka haluavat edelleen uudistaa ja kehittää pohjoismaista yhteistyötä Pohjoismaiden Euroopan yhteistyöhön osallistumisen laajenemisen valossa,

ovat sopineet seuraavasta:

\section{Johdantosäännös}

\section{1 artikla $(1,8)$}

Sopimuspuolten on pyrittävä säilyttämään ja edelleen kehittämään maiden välistä yhteistyötä oikeudellisella, sivistyksellisellä, sosiaalisella ja taloudellisella alalla, sekä liikenne- ja ympäristönsuojelukysymyksissä.

Sopimuspuolten on neuvoteltava keskenään niistä yhteisesti kiinnostavista kysymyksistä, joita käsitellään eurooppalaisissa ja muissa kansainvälisissä järjestöissä ja konferensseissa. 


\section{Oikeudellinen yhteistyö}

\section{2 artikla (9)}

Lakeja ja muita määräyksiä laadittaessa

Pohjoismaissa on muiden Pohjoismaiden kansalaisia kohdeltava yhdenvertaisesti oman maan kansalaisten kanssa. Tämä koskee yhteissopimuksen soveltamisaluetta.

Ensimmäisen kappaleen määräyksistä voidaan kuitenkin poiketa, jos kansalaisuusvaatimus johtuu perustuslaista, on tarpeen muiden kansainvälisten velvoitteiden johdosta tai jos tämä muista erityisistä syistä katsotaan tarpeelliseksi.

\section{3 artikla}

Sopimuspuolten on pyrittävä helpottamaan Pohjoismaiden kansalaisten kansalaisoikeuden saamista muussa Pohjoismaassa.

\section{4 artikla}

Sopimuspuolten on jatkettava lakiyhteistyötä mahdollisimman suuren yhdenmukaisuuden saavuttamiseksi yksityisoikeuden alalla.

\section{5 artikla}

Sopimuspuolten olisi pyrittävä yhdenmukaistamaan rikosta ja rikoksen seuraamuksia koskevat säännöksensä.

Toisessa Pohjoismaassa tehdyn rikoksen tutkinnan ja syytteeseen panon tulisi mahdollisimman laajalti voida tapahtua myös toisessa Pohjoismaassa.

\section{6 artikla}

Sopimuspuolten on pyrittävä muunkin kuin edellä mainitun lainsäädännön keskinäiseen yhtenäistämiseen sellaisilla aloilla, joilla tämä näyttää tarkoituksenmukaiselta.

\section{7 artikla}

Jokaisen sopimuspuolen olisi toimittava sellaisten säännösten aikaansaamiseksi, että toisen Pohjoismaan tuomioistuimen tai muun viranomaisen päätös voidaan panna täytäntöön myös asianomaisen sopimuspuolen alveella.

\section{Sivistyksellinen yhteistyö}

\section{8 artikla (2)}

Pohjoismaissa on kouluissa annettavaan opetukseen ja koulutukseen sopivassa laajuudessa sisällytettävä muiden Pohjoismaiden, mukaan luettuna Färsaarten, Grönlannin ja Ahvenanmaan kielten, kulttuurin ja yleisten yhteiskuntaolojen opetusta.

\section{9 artikla}

Jokaisen sopimuspuolen olisi opetuslaitoksissaan ylläpidettävä ja laajennettava toisesta Pohjoismaasta kotoisin olevan opiskelijan mahdollisuuksia harjoittaa opintoja ja suorittaa tutkintoja niissä. Tällöin olisi myös jossakin Pohjoismaassa suoritettu osatutkinto mahdollisimman laajalti voitava lukea hyväksi loppututkintoa varten muussa Pohjoismaassa.

Kotimaasta käsin annettava taloudellinen apu olisi voitava suorittaa riippumatta siitä, missä maassa opintoja harjoitetaan.

\section{0 artikla}

Sopimuspuolten olisi yhtenäistettävä sellainen julkinen koulutus, joka tarkoittaa pätevyyden antamista määrätyn ammatin harjoittamiseen.

Sellaisen koulutuksen olisi mikäli mahdollista annettava sama pätevyys kaikissa Pohjoismaissa. Kuitenkin voidaan vaatia sellaisia lisäopintoja, jotka kansallisiin oloihin liittyvistä syistä saattavat olla tarpeellisia.

\section{1 artikla}

Aloilla, joilla yhteistyö on tarkoituksenmukaista, olisi opetuslaitosten kehittäminen yhtenäistettävä kehittämissuunnitelmia ja niiden toteutusta koskevan jatkuvan yhteistoiminnan puitteissa. 


\section{2 artikla}

Yhteistyö tutkimuksen alalla olisi suunnattava siten, että käytettävissä olevat tutkimusmäärärahat ja muut voimavarat yhtenäistetään ja käytetään hyväksi parhaalla mahdollisella tavalla, muun muassa perustamalla yhteisiä laitoksia.

\section{3 artikla}

Sivistyksellisen kehityksen tukemiseksi ja vahvistamiseksi on sopimuspuolten edistettävä vapaata pohjoismaista kansansivistystyötä ja vuorovaikutusta kirjallisuuden, taiteen, musiikin, teatterin, filmin ja muilla kulttuurin aloilla; tällöin tulee muun muassa ottaa varteen radion ja television tarjoamat mahdollisuudet.

\section{Sosiaalinen yhteistyö}

\section{4 artikla}

Sopimuspuolten on pyrittävä säilyttämään ja edelleen kehittämään yhteisiä pohjoismaisia työmarkkinoita aikaisempien sopimusten sisältämien suuntaviivojen mukaisesti. Työnvälitys ja ammatinvalinnanohjaus on yhtenäistettävä. Harjoittelijain vaihdon on oltava vapaata.

Kansalliset työväensuojelua ja muita senlaatuisia kysymyksiä koskevat säännökset olisi pyrittävä yhdenmukaistamaan.

\section{5 artikla}

Sopimuspuolten on toimittava siihen suuntaan, että jonkin Pohjoismaan kansalainen oleskellessaan muussa Pohjoismaassa mahdollisimman laajalti pääsee osalliseksi oleskelumaan omille kansalaisilleen tarjoamista sosiaalisista eduista.

\section{6 artikla}

Sopimuspuolten on edelleen kehitettävä yhteistyötä terveyden- ja sairaanhoidon, raittiushuollon sekä lasten ja nuorisonhuollon alalla.

\section{7 artikla}

Jokaisen sopimusmaan on pyrittävä lääkinnöllisen, teknillisen tai muun sentapaisen turvallisuustarkastuksen suorittamiseen siten, että tarkastuksesta annettu todistus voidaan hyväksyä muissa Pohjoismaissa.

\section{Taloudellinen yhteistyö}

\section{8 artikla}

Sopimuspuolten on edistääkseen Pohjoismaiden taloudellista yhteistyötä eri aloilla neuvoteltava talouspolitiikasta. Tällöin on kiinnitettävä huomiota mahdollisuuksiin sopeuttaa toisiinsa toimenpiteet, joihin ryhdytään suhdanteiden tasoittamiseksi.

\section{9 artikla}

Sopimuspuolten tarkoituksena on siinä laajuudessa kuin mahdollista edistää maidensa välistä yhteistyötä tuotannon ja sijoitustoiminnan alalla ja tällöin pyrkiä lvomaan edellytykset välittömälle yhteistyölle kahdessa tai useammassa Pohjoismaassa olevien yritysten kesken. Sopimuspuolten olisi kansainvälistä yhteistyötä edelleen kehitettäessä pyrittävä maiden välillä tarkoituksenmukaiseen työnjakoon tuotannon ja sijoitustoiminnan alalla.

\section{0 artikla}

Sopimuspuolten on toimittava mahdollisimman laajan pääomansiirtojen vapauden hyväksi Pohjoismaiden välillä. Muissa osapuolia yhteisesti kiinnostavissa maksu- ja valuuttakysymyksissä on pyrittävä yhteisiin ratkaisuihin.

\section{1 artikla}

Sopimuspuolten on pyrittävä lujittamaan aikaisemmin aloitettua yhteistyötä kaupan esteiden poistamiseksi Pohjoismaiden väliltä sekä mahdollisimman laajalti edelleen vahvistamaan ja kehittämään tätä yhteistyötä. 


\section{2 artikla}

Sopimuspuolten on kansainvälisissä kauppapoliittisissa kysymyksissä pyrittävä niin hyvin kukin erikseen kuin yhteisesti edistämään Pohjoismaiden etuja ja tässä tarkoituksessa neuvoteltava keskenään.

\section{3 artikla}

Sopimuspuolten on toimittava tulliteknillisten ja tullihallinnollisten määräyksien yhtenäistämiseksi sekä tullitoiminnan yksinkertaistamiseksi siten että maiden välistä liikennettä voidaan helpottaa.

\section{4 artikla}

Pohjoismaista rajakauppaa koskevat määräykset on laadittava siten, että rajaseutujen asukkaille aiheutetaan mahdollisimman vähän haittaa.

\section{5 artikla}

Milloin tarve vaatii ja edellytykset kahden tai useamman sopimuspuolen alveen toisiinsa rajoittuvien osien yhteiseen taloudelliseen kehittämiseen ovat olemassa, on näiden osapuolten pyrittävä yhdessä edistämään sellaista kehitystyötä.

\section{Yhteistyö liikenteen alalla}

\section{6 artikla}

Sopimuspuolten on pyrittävä lujittamaan liikenteen alalla aikaisemmin aloitettua yhteistyötä ja kehittämään sitä maiden välisten yhteyksien ja tavaranvaihdon helpottamiseksi sekä sellaisten ongelmien tarkoituksenmukaiseksi ratkaisemiseksi, joita tällä alalla saattaa esiintyä.

\section{7 artikla}

Kahden tai useamman sopimuspuolen alvetta koskettavien liikenneyhteyksien rakentamisen on tapahduttava osapuolten välisten yhteisten neuvottelujen pohjalla.

\section{8 artikla}

Sopimuspuolten on pyrittävä säilyttämään ja edelleen kehittämään sitä yhteistyötä, joka on johtanut niiden alveiden muodostumiseen yhdeksi passintarkastusalueeksi. Pohjoismaiden välisen rajan ylittävien matkustajien tarkastusta on muutenkin yksinkertaistettava ja yhtenäistettävä.

\section{9 artikla}

Sopimuspuolten on yhtenäistettävä toiminta liikenneturvallisuuden lisäämiseksi.

\section{Yhteistyö ympäristönsuojelun alalla (3)}

\section{0 artikla (3)}

Sopimuspuolet pyrkivät mahdollisimman suuressa määrin sisäisessä lainsäädännössään ja sitä sovellettaessa samaistamaan muiden sopimuspuolten ympäristönsuojeluedut oman maan etuihin.

\section{1 artikla (3)}

Sopimuspuolet pyrkivät yhdenmukaistamaan ympäristönsuojelusääntönsä saavuttaakseen mahdollisimman suuren yhtenäisyyden saasteiden päästöä, ympäristömyrkkyjen käyttöä ja muita ympäristöhäiriöitä koskevien säännösten ja ohjeiden osalta.

\section{2 artikla (3)}

Sopimuspuolet pyrkivät yhtenäisiin ratkaisuihin luonnonsuojelu ja ulkoilualueiden erottamista sekä rauhoittamista ja muita kasvien tai eläinten suojelutoimenpiteitä koskevissa kysymyksissä.

\section{Muu yhteistyö}

\section{3 artikla (8)}

Sopimuspuolten osallistuminen eurooppalaiseen ja muuhun kansainväliseen yhteistyöhön antaa hyvät mahdollisuudet yhteistyöhön Pohjoismaiden kansalaisten ja pohjoismaisten yritysten hyväksi. Hallituksilla on tässä 
yhteydessä erityinen vastuu yhteisten etujen ja arvojen valvomisesta.

\section{4 artikla}

Sopimusmaan ulkoasiainhallinnossa Pohjoismaiden ulkopuolella toimivan virkamiehen on, siinä määrin kuin se on sopusoinnussa hänen virkatehtäviensä kanssa ja jos asemamaan taholta ei ole estettä, annettava apua myös muun Pohjoismaan kansalaiselle, jos tällä maalla ei ole edustustoa kysymyksessä olevalla paikkakunnalla.

\section{5 artikla}

Sopimuspuolten olisi aina silloin kun mahdolliseksi ja tarkoituksenmukaiseksi havaitaan, yhtenäistettävä toimintansa, joka tarkoittaa avunantoa kehitysmaille ja yhteistyötä niiden kanssa.

\section{6 artikla}

Toimenpiteisiin Pohjoismaiden ja pohjoismaisen yhteistyön tunnetuksi tekemiseksi olisi ryhdyttävä läheisessä yhteistyössä sopimuspuolten ja niiden ulkomaista tiedotustoimintaa hoitavien elinten kesken. Milloin tarkoituksenmukaiseksi katsotaan voivat yhteiset esiintymiset tulla kysymykseen.

\section{7 artikla}

Sopimuspuolten on toimittava virallisen tilaston eri haarojen yhtenäistämiseksi

\section{Erillissopimukset (3)}

\section{8 artikla (3)}

Tarkemmat määräykset yhteistyöstä tässä sopimuksessa mainituilla aloilla voidaan antaa erillissopimuksin.

\section{Pohjoismaisen yhteistyön muodot}

\section{9 artikla (4)}

Pohjoismaisen yhteistyön toteuttamiseksi ja edelleen kehittämiseksi tämän ja muiden sopimusten mukaisesti tulee Pohjoismaiden jatkuvasti neuvotella keskenään ja tarvittaessa ryhtyä yhdenmukaisiin toimenpiteisiin.

\section{0 artikla $(4,8)$}

Pohjoismaiden välinen yhteistyö tapahtuu Pohjoismaiden neuvostossa, Pohjoismaiden ministerineuvostossa sekä pääministereiden, ulkoministereiden ja muiden ministereiden kokouksissa, erityisissä yhteistyöelimissä ja maiden ammattiviranomaisten välillä.

\section{1 artikla}

Kahden tai useamman sopimuspuolen yhteistyöhön perustuvaa säännöstä älköön osapuoli muuttako ellei siitä ole ilmoitettu muille osapuolille. Kiireellisissä tapauksissa tai kun kysymyksessä on säännös, jolla ei ole sanottavaa merkitystä, ei ilmoitusta kuitenkaan vaadita.

\section{2 artikla}

Pohjoismaiden viranomaiset voivat olla välittömässä kirjeenvaihdossa keskenään muissa asioissa kuin sellaisissa, jotka luonteensa puolesta taikka muusta syystä on käsiteltävä ulkoasiainhallinnon välityksellä.

\section{3 artikla (3)}

Pohjoismaiden yhteistyössä on pyrittävä mahdollisimman laajaan julkisuuteen.

\section{Pohjoismaiden neuvosto (5)}

\section{4 artikla $(5,2)$}

Pohjoismaiden neuvostossa Pohjoismaiden sekä Färsaarten, Grönlannin ja Ahvenanmaan kansanedustuslaitokset, maiden hallitukset sekä Färsaarten ja Grönlannin maakuntahallitukset ja Ahvenanmaan maakuntahallitus ovat yhteistyössä keskenään. Neuvosto voi tehdä aloitteita ja antaa neuvoja niissä kysymyksissä, jotka koskevat yhteistyötä näiden maiden tai joidenkin niistä ja Färsaarten, Grönlannin ja Ahvenanmaan välillä, ja sillä on 
muutoin ne tehtävät, jotka ilmenevät tästä tai muista sopimuksista.

\section{5 artikla (5)}

Neuvosto voi hyväksyä suosituksia, tehdä muita esityksiä tai antaa lausuntoja yhdelle tai useammalle Pohjoismaan hallitukselle tai ministerineuvostolle.

\section{6 artikla (5)}

Neuvostolle on, sen lisäksi mitä erikseen on sovittu, varattava tilaisuus antaa lausuntonsa merkittävistä pohjoismaista yhteistyötä koskevista kysymyksistä, milloin tämä ajan puutteen vuoksi ei ole mahdotonta.

\section{7 artikla $(5,2,8)$}

Neuvoston muodostavat 87 valittua jäsentä, hallitusten edustajat sekä Färsaarten ja Grönlannin maakuntahallitusten ja Ahvenanmaan maakunnanhallituksen edustajat.

Jäsenistä valitsevat Tanskan kansankäräjät kuusitoista, Suomen eduskunta kahdeksantoista, Islannin altingi seitsemän, Norjan suurkäräjät ja Ruotsin valtiopäivät kumpikin kaksikymmentä sekä Färsaarten ja Grönlannin maakäräjät ja Ahvenanmaan maakuntapäivät valitsevat jokainen kaksi jäsentä. Sen lisäksi kukin kansanedustuslaitos valitsee vastaavan määrän varajäseniä.

Jäsenet ja varajäsenet valitaan vuosittain, ja vaali on voimassa siksi kunnes seuraava vaali toimitetaan. Vaaleissa on erilaisten poliittisten suuntausten saatava edustus neuvostossa.

Ainoastaan se, joka on vaalin toimittaneen kansanedustuslaitoksen jäsen, voi toimia neuvoston valittuna jäsenenä ja varajäsenenä.

Hallitukset ja maakuntahallitukset määräävät jäsenistään halvamansa määrän edustajia.

\section{8 artikla $(5,2,8,9)$}

Tanskan valtakunnan valtuuskunnan muodostavat kansankäräjien valitsemat jäsenet ja hallituksen määräämät edustajat sekä Färsaarten ja Grönlannin toisessa kappaleessa mainitut valtuuskunnat. Suomen valtuuskunnan muodostavat eduskunnan valitsemat jäsenet ja hallituksen määräämät edustajat sekä toisessa kappaleessa mainittu Ahvenanmaan valtuuskunta. Kunkin muun maan valtuuskunnan muodostavat kansanedustuslaitoksen valitsemat jäsenet ja hallituksen määräämät edustajat.

Färsaarten valtuuskunnan muodostavat maakäräjien valitsemat jäsenet ja maakuntahallituksen määräämät edustajat. Grönlannin valtuuskunnan muodostavat maakäräjien valitsemat jäsenet ja maakuntahallituksen määräämät edustajat. Ahvenanmaan valtuuskunnan muodostavat maakuntapäivien valitsemat jäsenet ja maakuntahallituksen määräämät edustajat.

Valtuuskunta tarkoittaa 58 artiklan 2 kappaleessa maan valtuuskuntaa.

\section{9 artikla $(5,2)$}

Hallitusten sekä maakuntahallitusten ja maakunnanhallituksen edustajilla ei ole äänioikeutta neuvostossa.

Maiden välisten sopimusten soveltamista koskevissa kysymyksissä on ainoastaan näitä maita edustavilla jäsenillä äänioikeus.

\section{0 artikla (5)}

Neuvoston elimiä ovat yleiskokous, puheenjohtajisto ja valiokunnat.

\section{$\mathbf{5 1}$ artikla $(5,7,9)$}

Yleiskokouksen muodostavat kaikki neuvoston jäsenet.

Yleiskokous pitää vähintään kerran vuodessa varsinaisen istuntonsa. Ylimääräinen istunto tai aihekohtainen istunto pidetään, kun puheenjohtajisto niin päättää tai milloin vähintään kaksi hallitusta tai vähintään kaksikymmentäviisi valittua jäsentä sitä pyytävät. 
Yleiskokous käyttää neuvoston toimivaltaa, jollei muuta ole erikseen määrätty.

Asiain käsittely yleiskokouksessa on julkista, ellei yleiskokous toisin päätä.

\section{$\mathbf{5 2}$ artikla $(5,6,7,9)$}

Yleiskokous valitsee kalenterivuodeksi kerrallaan vuotuisessa varsinaisessa istunnossa puheenjohtajiston, johon kuuluvat presidentti ja Pohjoismaiden neuvoston työjärjestyksessä mainittu määrä muita jäseniä.

Eri poliittisten mielipidesuuntausten on oltava edustettuna puheenjohtajistossa. Kunkin maan tulee olla edustettuna puheenjohtajistossa.

Puheenjohtajiston jäsenen on oltava neuvoston valittu jäsen.

Puheenjohtajisto huolehtii neuvoston juoksevien asiain hoidosta ja edustaa muutoin neuvostoa siinä laajuudessa kuin tästä sopimuksesta ja neuvoston työjärjestyksestä ilmenee.

Neuvoston presidenttiys kiertää Pohjoismaiden kesken Pohjoismaiden neuvoston työjärjestyksestä ilmenevällä tavalla.

\section{$\mathbf{5 3}$ artikla $(5,9)$}

Yleiskokous määrää valiokuntien lukumäärän ja toimialat.

Valiokuntien tehtävänä on valmistella asioiden käsittelyä neuvostossa.

\section{$\mathbf{5 4}$ artikla $(5,6,7,9)$}

Neuvostoa avustaa sen toiminnassa puheenjohtajiston sihteeristö.

\section{$\mathbf{5 5}$ artikla $(5,2,7,9)$}

Oikeus tehdä ehdotuksia neuvostolle on hallituksilla, Färsaarten maakuntahallituksella, Grönlannin maakuntahallituksella, Ahvenanmaan maakuntahallituksella, ministerineuvostolla, neuvoston puheenjohtajistolla ja valiokunnilla sekä jäsenellä.

\section{6 artikla $(5,7)$}

Yleiskokous hyväksyy suosituksen tehdyn ehdotuksen pohjalta.

Puheenjohtajisto voi tehdä muunlaisen esityksen kuin suosituksen tehdyn ehdotuksen johdosta.

Yleiskokous antaa lausuntoja. Milloin puheenjohtajisto tekee esityksen, lausunnon antaa puheenjohtajisto.

Puheenjohtajiston on ilmoitettava yleiskokoukselle niistä toimenpiteistä, joihin se on toisen ja kolmannen kappaleen nojalla ryhtynyt.

\section{$\mathbf{5 7}$ artikla $(5,7)$}

Valittu jäsen voi tehdä kysymyksen hallitukselle tai ministerineuvostolle neuvostolle annetun kertomuksen tai ilmoituksen johdosta tai muutoin pohjoismaista yhteistyötä koskevassa asiassa.

\section{8 artikla $(5,2,7)$}

Jokainen valtuuskunta vastaa neuvoston toimintaan osallistumisestaan aiheutuvista kustannuksista.

Puheenjohtajisto päättää jokaisen varainhoitovuoden osalta siitä, miten yhteiset kustannukset jaetaan valtuuskuntien kesken.

\section{9 artikla (5)}

Yleiskokous vahvistaa neuvoston työjärjestyksen. Työjärjestyksen hyväksymiseen tai muuttamiseen vaaditaan kahden kolmasosan enemmistö neuvoston valituista jäsenistä.

\section{Pohjoismaiden ministerineuvosto (5)}

\section{0 artikla $(5,2)$}

Pohjoismaiden ministerineuvosto on Pohjoismaiden hallitusten yhteistyöelin.

Färsaarten ja Grönlannin maakuntahallitukset sekä Ahvenanmaan maakunnanhallitus ottavat osaa ministerineuvoston työhön. 
Ministerineuvosto tekee päätöksiä siinä laajuudessa kuin käy ilmi tästä sopimuksesta ja muista Pohjoismaiden välisistä sopimuksista. Muissakin yhteistyökysymyksissä ministerineuvosto vastaa Pohjoismaiden hallitusten sekä hallitusten ja Pohjoismaiden neuvoston välisestä yhteistyöstä.

\section{1 artikla $(5,1,2,8)$}

Hallituksen ja maakuntahallituksen jäseniä voi poikkeustapauksessa edustaa siihen valtuutettu henkilö. Kuitenkin on vähintään kolmea maata edustettava hallituksen jäsen.

Pääministereillä on vastuu pohjoismaisten yhteistyökysymysten yhteensovittamisesta. Heitä avustaa valittu hallituksen jäsen kustakin maasta (yhteistyöministeri) sekä valtiosihteeri tai virkamies (Pohjoismaiden yhteistyökomitean jäsen).

Puheenjohtajuus kiertää Pohjoismaiden hallitusten kesken erikseen sovittavalla tavalla. Puheenjohtajuuteen kuuluu vastuu Pohjoismaiden hallitusyhteistyön yhteensovittamisesta ja tarpeellisten aloitteiden tekemisestä. Puheenjohtajuuteen kuuluu ministerineuvoston ja muiden ministerikokousten sekä hallitusten eurooppalaisten ja muiden kansainvälisten kysymysten yhteisneuvottelujen työn johtaminen.

Ministerineuvostoa avustavat sen toiminnassa virkamieskomiteat ja ministerineuvoston sihteeristö.

\section{$\mathbf{6 2}$ artikla (5)}

Päätösvaltaisuus edellyttää, että kaikki maat ovat edustettuina ministerineuvostossa. Yksinomaan joitakin maita koskevien kysymysten käsittelyssä kuitenkin vain näiden maiden tulee olla edustettuina.

Jokaisella maalla on yksi ääni ministerineuvostossa.

Ministerineuvoston päätösten tulee olla yksimielisiä. Menettelytapakysymyksissä tehdään kuitenkin päätös äänestykseen osallistuvien yksinkertaisella äänten enemmistöllä ja äänten mennessä tasan puheenjohtajan ääni ratkaisee.

Äänestyksestä pidättyminen ei estä päätöksen tekemistä.

\section{3 artikla $(5,2,8)$}

Ministerineuvoston päätös on kutakin maata sitova. Päätös kysymyksessä, joka jonkin maan valtiosäännön mukaan edellyttää kansanedustuslaitoksen hyväksymistä, ei kuitenkaan ole tätä maata sitova ennen kuin kansanedustuslaitos on hyväksynyt päätöksen. Jos sanotunlainen hyväksyminen vaaditaan, on ministerineuvostolle ilmoitettava tästä ennen kuin ministerineuvosto tekee päätöksensä. Ennen kuin kansanedustuslaitoksen hyväksyminen on saatu, päätös ei ole myöskään toista maata sitova.

Tämän sopimuksen mukaisesti tehty päätös on Färsaaria, Grönlantia ja Ahvenanmaata sitova siltä osin kuin ne yhtyvät päätökseen itsehallintojärjestelmiensä mukaisesti.

\section{4 artikla $(5,6,8)$}

Ministerineuvoston tulee vuosittain antaa Pohjoismaiden neuvostolle kertomus pohjoismaisesta yhteistyöstä sekä selvitys tulevaa yhteistyötä koskevista suunnitelmista.

Puheenjohtajamaan pääministeri selostaa Pohjoismaiden neuvostolle yhteistyön päälinjat sekä hallitusten yhteistyön Eurooppaa koskevissa ja muissa kansainvälisissä kysymyksissä.

Ministerineuvoston tulee esittää menoarvioehdotuksensa Pohjoismaiden neuvostolle lausuntoa varten.

Pohjoismaiden neuvosto voi ehdottaa muutoksia painopistealueisiin ministerineuvoston esittämän budjettikehyksen puitteissa.

Ellei erityisiä syitä voida esittää, on ministerineuvoston noudatettava suositusta määrärahakäytöstä esitetyn budjettikehyksen puitteissa. 


\section{5 artikla (5)}

Ministerineuvoston tulee ennen jokaista Pohjoismaiden neuvoston yleiskokouksen varsinaista istuntoa antaa neuvostolle ilmoitukset niistä toimenpiteistä, joihin on ryhdytty neuvoston suositusten ja muiden esitysten johdosta. Jos suositus tai muu esitys on osoitettu yhdelle tai useammalle hallitukselle, voi ilmoituksen sen sijaan antaa se hallitus tai ne hallitukset, joille suositus tai esitys oli osoitettu.

\section{6 artikla (5)}

Ministerineuvosto vahvistaa työjärjestyksensä.

\section{7 artikla (5)}

Paitsi ministerineuvostossa voivat Pohjoismaiden hallitukset neuvotella keskenään myös pohjoismaisissa ministerikokouksissa.

\section{Yhteistyösopimuksen muuttaminen (5)}

\section{8 artikla (5)}

Ennen kuin maiden kesken sovitaan tämän yhteistyösopimuksen muuttamisesta, on Pohjoismaiden neuvostolle varattava tilaisuus antaa lausuntonsa.

\section{Loppumääräykset}

\section{Maaliskuun 23 päivänä 1962 allekirjoitetun} sopimuksen loppumääräykset

\section{9 artikla}

Tämä sopimus on ratifioitava ja ratifioimiskirjat mahdollisimman pian talletettava Suomen ulkoasiainministeriöön.

Sopimus tulee voimaan sen kuukauden ensimmäisenä päivänä, joka lähinnä seuraa päivää, jona kaikkien sopimuspuolten ratifioimiskirjat on talletettu.

\section{0 artikla}

Jos jokin sopimuspuoli haluaa irtisanoa sopimuksen, on siitä kirjallisesti ilmoitettava
Suomen hallitukselle, jonka viipymättä tulee antaa asiasta sekä ilmoituksen vastaanottamispäivästä tieto muille sopimuspuolille.

Irtisanominen koskee ainoastaan irtisanomisilmoituksen tehnyttä maata ja tulee voimaan sen kuukauden ensimmäisenä päivänä, joka alkaa kuuden kuukauden kuluttua siitä päivästä, jona Suomen hallitus vastaanotti irtisanomisilmoituksen.

Sopimus on talletettava Suomen ulkoasiainministeriöön ja oikeaksi todistetut jäljennökset siitä on Suomen ulkoasiainministeriön toimitettava kaikille sopimuspuolille.

Tämän vakuudeksi allekirjoittaneet, asianmukaisesti valtuutettuina, ovat allekirjoittaneet tämän sopimuksen.

Tehty Helsingissä yhtenä kappaleena islannin, norjan, ruotsin, suomen ja tanskan kielellä, jokaisen tekstin ollessa yhtä todistusvoimainen, kahdentenakymmenentenäkolmantena päivänä maaliskuuta yhdeksäntoistasataakuusikymmentäkaksi.

$[--]$

\section{3 päivänä helmikuuta 1971 allekirjoitetun} sopimuksen loppumääräykset

Tämä sopimus on ratifioitava ja ratifioimiskirjat mahdollisimman pian talletettava Suomen ulkoasiainministeriöön.

Sopimus on talletettava Suomen ulkoasiainministeriöön, jonka on toimitettava jokaiselle sopimuksen osapuolelle oikeaksi todistettu jäljennös sopimuksesta.

Sopimus tulee voimaan kolmantenakymmenentenä päivänä sen päivän jälkeen, jona kaikkien sopimuspuolten ratifioimiskirjat on talletettu.

Tämän vakuudeksi ovat allekirjoittaneet valtuutetut asiamiehet Kööpenhaminassa 13 päivänä helmikuuta 1971 allekirjoittaneet tämän sopimuksen, joka on tehty yhtenä islannin-, norjan-, ruotsin-, suomen- ja tanskankielisenä kappaleena jokaisen tekstin ollessa yhtä todistusvoimainen.

$[--]$ 
11 päivänä maaliskuuta 1974 allekirjoitetun sopimuksen loppumääräykset

Tämä sopimus on ratifioitava ja ratifioimiskirjat mahdollisimman pian talletettava Suomen ulkoasiainministeriöön.

Sopimus on talletettava Suomen ulkoasiainministeriöön, jonka on toimitettava jokaiselle sopimuksen osapuolelle oikeaksi todistettu jäljennös sopimuksesta.

Sopimus tulee voimaan kolmantenakymmenentenä päivänä sen jälkeen, jona kaikkien sopimuspuolten ratifioimiskirjat on talletettu.

Tämän vakuudeksi ovat allekirjoittaneet valtuutetut asiamiehet Kööpenhaminassa 11 päivänä maaliskuuta 1974 allekirjoittaneet tämän sopimuksen, joka on tehty yhtenä islannin-, norjan-, ruotsin-, suomen- ja tanskankielisenä kappaleena jokaisen tekstin ollessa yhtä todistusvoimainen. $[--]$

\section{5 päivänä kesäkuuta 1983 allekirjoitetun} sopimuksen loppumääräykset

Tämä sopimus on ratifioitava ja ratifioimiskirjat mahdollisimman pian talletettava Suomen ulkoasiainministeriöön, jonka on toimitettava jokaiselle sopimuksen osapuolelle oikeaksi todistettu jäljennös sopimuksesta.

Sopimus tulee voimaan kolmantenakymmenentenä päivänä sen päivän jälkeen, jona kaikkien sopimuspuolten ratifioimiskirjat on talletettu.

Tämän vakuudeksi ovat allekirjoittaneet valtuutetut asiamiehet Reykjavikissa 15 päivänä kesäkuuta 1983 allekirjoittaneet tämän sopimuksen, joka on tehty yhtenä islannin-, norjan-, ruotsin-, suomen- ja tanskankielisenä kappaleena jokaisen tekstin ollessa yhtä todistusvoimainen.

[- ]
6 päivänä toukokuuta 1985 allekirjoitetun sopimuksen loppumääräykset

Sopimus tulee voimaan kolmantenakymmenentenä päivänä siitä päivästä, jona kaikki sopimuspuolet ovat ilmoittaneet sopimuksen voimaansaattamiseksi vaadittavien toimenpiteiden suorittamisesta.

Suomen ulkoasiainministeriö ilmoittaa muille sopimuspuolille näiden hyväksymisilmoitusten vastaanottamispäivästä.

Sopimuksen alkuperäiskappale talletetaan Suomen ulkoasiainministeriön huostaan, joka toimittaa siitä oikeaksi todistetun jäljennöksen jokaiselle sopimuspuolelle.

Tämän vakuudeksi ovat asianmukaisesti valtuutetut allekirjoittaneet tämän sopimuksen.

Tehty Lundissa 6 päivänä toukokuuta 1985 yhtenä islannin-, norjan-, ruotsin-, suomen- ja tanskankielisenä kappaleena, jonka kaikki tekstit ovat yhtä todistusvoimaiset.

$[--]$

\section{1 päivänä elokuuta 1991 allekirjoitetun} sopimuksen loppumääräykset

Sopimus tulee voimaan kolmenkymmenen päivän kuluttua siitä, kun kaikki osapuolet ovat ilmoittaneet Suomen ulkoasiainministeriölle sopimuksen hyväksymisestä.

Suomen ulkoasiainministeriö ilmoittaa muille osapuolille näiden ilmoitusten vastaanottamisesta ja sopimuksen voimaantuloajankohdasta.

Tämän sopimuksen alkuperäiskappale talletetaan Suomen ulkoasiainministeriön huostaan, joka toimittaa siitä muille osapuolille oikeaksi todistetun jäljennöksen.

Tämän vakuudeksi ovat asianmukaisesti valtuutetut edustajat allekirjoittaneet tämän sopimuksen.

Tehty Tampereella 21 päivänä elokuuta 1991 yhtenä tanskan-, suomen-, islannin-, norjan- ja ruotsinkielisenä kappaleena, jonka kaikki tekstit ovat yhtä todistusvoimaiset. [- - ] 
18 päivänä maaliskuuta 1993 allekirjoitetun sopimuksen loppumääräykset

Sopimus tulee voimaan kolmenkymmenen päivän kuluttua siitä, kun kaikki osapuolet ovat ilmoittaneet Suomen ulkoasiainministeriölle sopimuksen hyväksymisestä.

Suomen ulkoasiainministeriö ilmoittaa muille osapuolille näiden ilmoitusten vastaanottamisesta ja sopimuksen voimaantuloajankohdasta.

Tämän sopimuksen alkuperäiskappale talletetaan Suomen ulkoasiainministeriön huostaan, joka toimittaa siitä muille osapuolille oikeaksi todistetun jäljennöksen.

Tämän vakuudeksi ovat asianmukaisesti valtuutetut edustajat allekirjoittaneet tämän sopimuksen.

Tehty Helsingissä 18 päivänä maaliskuuta 1993 yhtenä tanskan-, suomen-, islannin-, norjan- ja ruotsinkielisenä kappaleena, jonka kaikki tekstit ovat yhtä todistusvoimaiset. $[--]$

29 päivänä syyskuuta 1995 allekirjoitetun sopimuksen loppumäcäräykset Sopimus tulee voimaan viidentoista päivän kuluttua siitä, kun kaikki osapuolet ovat ilmoittaneet Suomen ulkoasiainministeriölle sopimuksen hyväksymisestä.

Suomen ulkoasiainministeriö ilmoittaa muille osapuolille näiden ilmoitusten vastaanottamisesta ja sopimuksen voimaantuloajankohdasta.

Tämän sopimuksen alkuperäiskappale talletetaan Suomen ulkoasiainministeriön huostaan, joka toimittaa siitä muille osapuolille oikeaksi todistetun jäljennöksen.

Tämän vakuudeksi ovat asianmukaisesti valtuutetut edustajat allekirjoittaneet tämän sopimuksen.

Tehty Kööpenhaminassa 29 päivänä syyskuuta 1995 yhtenä tanskan-, suomen-, islannin-, norjan- ja ruotsinkielisenä kappaleena, jonka kaikki tekstit ovat yhtä todistusvoimaiset.

$[--]$

\section{Viiteluettelo}

1 Uusi sanamuoto 1974.

2 Uusi sanamuoto 1983.

3 Uusi artikla vuodesta 1974.

4 Uusi sanamuoto 1971.

5 Uusi artikla vuodesta 1971.

6 Uusi sanamuoto 1985.

7 Uusi sanamuoto 1991.

8 Uusi sanamuoto 1993.

9 Uusi sanamuoto 1995. 


\section{Helsingforssamningurinn}

Samstarfssamningur milli Danmerkur, Finnlands, Íslands, Noregs og Svípjóðar

(Helsingforssamningurinn).

Samningurinn var undirritaður 23. mars 1962 og öðlaðist gildi 1. júlí sama ár. Hinn upprunalegi texti hefur verið endurskoðaður í samræmi við samninga er undirritaðir voru 13. febrúar 1971, 11. mars 1974, 15. júní 1983, 6. maí 1985, 21. ágúst 1991, 18. mars 1993 og 29. september 1995. Sídustu breytingar gengu í gildi 2. janúar 1996.

Inngangur að̃ samningnum

\section{3. mars 1962}

Ríkisstjórnir Danmerkur, Finnlands, Íslands, Noregs og Svípjóðar,

sem efla vilja enn betur hin nánu menningartengsl Norðurlandapjóðanna og samstöðu peirra í skoðunum á réttarog pjóðfélagsmálum og auka enn samstarfið milli Norðurlanda;

sem keppa vilja að sameiginlegum reglum á Norðurlöndum í svo mörgum greinum, sem unnt er;

sem koma vilja fram hagkvæmri verkaskiptingu milli landanna á öllum sviðum, par sem skilyrði eru til pess;

sem halda vilja áfram samstarfi pessara landa, sem peim er mikilvægt, í Norðurlandaráði og öðrum samstarfsstofnunum; hafa orðið sammála um eftirfarandi ákvæði:

\section{Inngangur að̃ samningnum}

\section{3. febrúar 1971}

Ríkisstjórnir Danmerkur, Finnlands, Íslands, Noregs og Svípjóðar, sem vilja treysta og efla enn grundvöll samstarfs Norðurlanda og skipulag; sem telja ráðvænlegt að breyta í pessu skyni samstarfssamningi Norðurlanda frá 23. marz 1962;

sem hafa pess vegna ákveðið að fella inn í samstarfssamninginn grundvallarákvæði pau, er Norðurlandaráð varða;

sem jafnframt hafa ákveðið að bæta inn í samstarfssamninginn ákvæðum um ráðherranefnd Norðurlanda, en undir hana falla málefni norrænnar samvinnu, hafa orðið sammála um eftirfarandi:

\section{Inngangur đð̆ samningnum}

\section{1. mars 1974}

Ríkisstjórnir Danmerkur, Finnlands, Íslands, Noregs og Svípjóðar,

sem með samkomulaginu frá 13. febrúar 1971 hafa breytt samstarfssamningnum frá 23. mars 1962,

sem telja ráðvænlegt að gera ákveðnar frekari breytingar á samningnum og auka við hann,

hafa orðið sammála um eftirfarandi:

\section{Inngangur đð̃ samningnum}

\section{5. júní 1983}

Ríkisstjórnir Danmerkur, Finnlands, Íslands, Noregs og Svípjóðar,

sem með samkomulagi frá 13. febrúar 1971 og samkomulagi frá 11. mars 1974 hafa breytt samstarfssamningnum frá 23. mars 1962,

sem telja ráðvænlegt að gera breytingar á samningnum í peim tilgangi að veita Álandseyjum og Færeyjum aukna aðild að Norðurlandaráði og ráðherranefnd Norðurlandaráðs og einnig til að veita Grænlandi samsvarandi aðild að pessum stofnunum,

hafa orðið sammála um eftirfarandi: 
Inngangur að̃ samningnum

\section{6. maí 1985}

Ríkisstjórnir Danmerkur, Finnlands, Íslands, Noregs og Svípjóðar, sem með samkomulagi frá 13. febrúar

1971, 11. mars 1974 og 15. júní 1983 hafa

breytt samstarfssamningnum frá 23. mars 1962 milli Norðurlandanna, og sem óska að starfshættir i norrænni

samvinnu verði árangursríkari, hafa orðið sammála um eftirfarandi:

\section{Inngangur að̃ samningnum}

\section{1. ágúst 1991}

Ríkisstjórnir Danmerkur, Finnlands, Íslands, Noregs og Svípjóðar, sem með samkomulagi frá 13. febrúar 1971, 11. mars 1974, 15. júní 1983 og 6. maí 1985 hafa breytt samstarfssamningnum frá

23. mars 1962 milli Norðurlandanna, og sem telja ráðvænlegt að gera tilteknar breytingar á skipulagi og starfsháttum Norðurlandaráðs, hafa orðið sammála um eftirfarandi:

\section{Inngangur að̃ samningnum}

\section{8. mars 1993}

Ríkisstjórnir Danmerkur, Finnlands, Íslands, Noregs og Svípjóðar, sem með samkomulagi frá 13 . febrúar 1971, 11. mars 1974, 15. júní 1983, 6. maí 1985 og 21. ágúst 1991 hafa breytt samstarfssamningnum frá

23. mars 1962 milli Norðurlandanna, og sem óska pess að endurnýja og efla norræna samvinnu i ljósi aukinnar pátttöku Norðurlandanna i evrópskri samvinnu, hafa orðið sammála um eftirfarandi:

\section{Inngangur að̃ samningnum}

\section{9. september 1995}

Ríkisstjórnir Danmerkur, Finnlands, Íslands, Noregs og Svípjóðar, sem með samkomulagi frá 13. febrúar 1971, 11. mars 1974, 15. júní 1983, 6. maí 1985, 21. ágúst 1991 og 18. mars 1993 hafa breytt samstarfssamningnum frá 23. mars 1962 milli Norðurlandanna, og

sem óska pess að endurnýja og próa enn frekar norrænt samstarf i ljósi aukinnar pátttöku Norðurlanda i evrópskri samvinnu, hafa orðið sammála um eftirfarandi:

\section{Inngangsákvæơi}

\section{1. grein $(1,8)$}

Samningsaðilar skulu kappkosta að varðveita og efla enn frekar samstarf ríkjanna á sviði réttarfars, menningarmála, félagsmála og efnahagsmála, svo og um samgöngur og umhverfisvernd.

Samningsaðilar skulu ráðgast hver við annan um sameiginleg hagsmunamál sem eru til umfjöllunar í evrópskum og öðrum alpjóðlegum stofnunum og á evrópskum og öðrum alpjóðlegum ráðstefnum.

\section{Réttarsamstarf}

\section{2. grein (9)}

Við setningu laga og annarra réttarreglna á Norðurlöndum skulu ríkisborgarar annarra norrænna landa njóta sama réttar og ríkisborgarar viðkomandi lands. Petta gildir á pví sviði sem samstarfssamningurinn tekur til.

Undanpágu frá 1. mgr. má pó gera, ef skilyrði um ríkisborgararétt er bundið í stjórnarskrá, nauðsynlegt vegna annarra alpjóðlegra skuldbindinga eða pað telst nauðsynlegt af öðrum sérstökum ástæðum.

\section{3. grein}

Samningsaðilar skulu leitast við að auðvelda ríkisborgurum Norðurlanda að hljóta ríkisfang í einhverju hinna landanna.

\section{4. grein}

Samningsaðilar skulu halda áfram löggjafarsamstarfi í pví skyni að ná sem mestu samræmi á sviði einkamálaréttar. 


\section{5. grein}

Samningsaðilum ber að leitast við að samræma reglur um afbrot og lögfylgjur peirra.

Hafi afbrot verið framið i einhverju Norðurlandanna, ber að keppa að pví, að rannsókn, málshöfðun og dómur geti einnig farið fram, svo sem framast er unnt, í einhverju hinna.

\section{6. grein}

Samningsaðilar skulu leitast við að ná samræmi sín á milli um aðra löggjöf en nú hefur verið nefnd á peim sviðum, par sem hagkvæmt pykir.

\section{7. grein}

Sérhverjum samningsaðila ber að vinna að pví, að settar verði reglur um að úrskurðir dómstóls eða annars yfirvalds í einhverju Norðurlandanna geti einnig hlotið fullnustu á umráðasvæði hans.

\section{Samstarf í menningarmálum}

\section{8. grein (2)}

Fræðsla og menntun í skólum í sérhverju Norðurlandanna skal í hæfilegum mæli taka til fræðslu í tungumálum og um menningu og almennt pjóðfélagsástand á hinum Norðurlöndunum, par með töldum Álandseyjum, Færeyjum og Grænlandi.

\section{9. grein}

Sérhverjum samningsaðila ber að halda við og auka möguleika fyrir námsmenn, sem heima eiga í öðru Norðurlanda, til að stunda nám og preyta próf við fræðslustofnanir hans. Skal pá, svo sem framast er unnt, leyft að taka gilt próf í hluta námsgreinar í einu landanna við lokapróf í einhverju hinna.

Nemandi ætti að geta fengið styrk frá landi sínu án tillits til pess í hvaða landi námið er stundað.

\section{0. grein}

Samningsaðilum ber að samræma pá fræðslu, sem veitt er af opinberri hálfu og miðar að pví að veita heimild til að stunda ákveðna atvinnu.

Slík menntun ætti, svo sem unnt er, að veita sömu réttindi í sérhverju Norðurlandanna. Krefjast má pó peirrar viðbótarmenntunar, sem nauðsynleg kann að vera vegna aðstæðna hverrar pjóðar um sig.

\section{1. grein}

Pegar um er að ræða að koma á fót fræðslustofnunum ber að hafa samstarf á peim sviðum, sem hentugt pykir, með stöðugri samvinnu um áætlanir, sem um petta eru gerðar og framkvæmd peirra.

\section{2. grein}

Samstarfi í rannsóknum ber að haga bannig, að tiltækar fjárveitingar til rannsókna og önnur framlög til peirra verði samræmd og notuð á pann hátt, sem beztur er, m.a. með pví að setja á fót sameiginlegar stofnanir.

\section{3. grein}

Í pví skyni að styðja og efla menningarpróunina, skulu samningsaðilar stuðla að frjálsu lýðfræðslustarfi á Norðurlöndum og samskiptum á sviði bókmennta, lista, tónlistar, leiklistar, kvikmynda og annarra menningarmála, m.a. með pví að nýta pá möguleika, sem útvarp og sjónvarp hafa að bjóða.

\section{Samstarf í félagsmálum}

\section{4. grein}

Samningsaðilar skulu leitast við að varðveita og próa enn betur hinn sameiginlega norræna vinnumarkað samkvæmt peim meginstefnum, sem markaðar hafa verið með fyrri samningum. Vinnumiðlun og starfsfræðsla skulu samræmdar. Frjáls skulu skipti á nemum í verknámi.

Stefna ber að samræmi í reglum hinna einstöku landa um vernd verkafólks og svipuð mál. 


\section{5. grein}

Samningsaðilar skulu vinna að pví, að ríkisborgarar Norðurlanda, sem dveljast í öðru Norðurlandanna en eigin landi, skuli svo sem framast er unnt njóta peirra félagslegu hlunninda, sem ríkisborgarar dvalarlandsins njóta.

\section{6. grein}

Samningsaðilar skulu auka enn samstarfið að heilsugæzlu- og sjúkramálum, og umönnun áfengissjúklinga, svo og barnavernd og unglinga.

\section{7. grein}

Sérhver samningsaðili skal vinna að pví, að læknisfræðilegt, tæknilegt eða annað ápekkt öryggiseftirlit sé framkvæmt á pann hátt, að skírteini eða vottorð um eftirlitið sé tekið gilt í hinum Norðurlöndunum.

\section{Samstarf í efnahagsmálum}

\section{8. grein}

Samningsaðilar skulu hafa samráð um stefnuna í efnahagsmálum til pess að efla efnahagssamstarf Norðurlanda á ýmsum sviðum. Skal pá hyggja að möguleikum á pví að samræma ráðstafanir, sem gerðar eru til jöfnunar á hagsveiflum.

\section{9. grein}

Samningsaðilar hyggjast stuðla svo sem unnt er að framleiðslu- og fjárfestingarsamvinnu milli landa sinna og leitast pá við að hagræða svo aðstöðu að auðveldað verði beint samstarf milli fyrirtækja í tveimur eða fleiri Norðurlandanna. Samningsaðilar skulu kappkosta að ná hagkvæmri verkaskiptingu milli landanna varðandi framleiðslu og fjárfestingu sem pætti í víðtækara alpjóðlegu samstarfi.

\section{0. grein}

Samningsaðilar skulu vinna að pví að fjármagnshreyfingar milli Norðurlandanna verði svo frjálsar sem framast er unnt.
Leitast skal við að leysa í sameiningu önnur greiðslu- og gjaldeyrismál, sem eru sameiginleg hagsmunamál.

\section{1. grein}

Samningsaðilar skulu leitast við að treysta pað samstarf, sem áður er hafið í pví skyni að ryðja úr vegi hindrunum fyrir verzlunarviðskiptum milli Norðurlanda, svo og að efla og auka petta samstarf svo sem framast er unnt.

\section{2. grein}

Samningsaðilar skulu bæði hver um sig og sameiginlega leitast við að hlynna að hagsmunum Norðurlanda í alpjóðlegum viðskiptamálum og ráðgast við í pví skyni.

\section{3. grein}

Samningsaðilar skulu vinna að samræmingu ákvæða um tæknileg atriði í tollamálum og stjórn tollamála, svo og að breytingum til einfaldari tilhögunar í tollamálum, sem til pess eru fallnar að auðvelda samskipti milli landanna.

\section{4. grein}

Ákvæði um landamæraverzlun á Norðurlöndum skulu pannig gerð, að pau valdi íbúum landamærahéraðanna sem minnstum ópægindum.

\section{5. grein}

Pegar pörf er á og skilyrði eru til sameiginlegra efnahagslegra framkvæmda í samliggjandi héruðum tveggja eða fleiri samningsaðila, skulu peir aðilar leitast við að stuðla að peim framkvæmdum í sameiningu.

\section{Samstarf í samgöngumálum}

\section{6. grein}

Samningsaðilar skulu leitast við að treysta pað samstarf, sem áður er hafið í samgöngumálum, svo og reyna að auka pað samstarf 
í peim tilgangi að auðvelda samgöngur og vöruskipti milli landanna og finna hagkvæma lausn peirra vandamála, sem kunna að vera á pessu sviði.

\section{7. grein}

Gerð samgönguleiða um landsvæði tveggja eða fleiri samningsaðila skal framkvæmd með samráði milli hlutaðeigandi aðila.

\section{8. grein}

Samningsaðilar skulu leitast við að varðveita og auka pað samstarf, sem orðið hefur til pess að lönd peirra eru eitt umdæmi að pví er vegabréfaskoðun varðar. Eftirlit með ferðamönnum, sem fara yfir landamæri milli Norðurlandanna, skal einnig að öðru leyti gera einfaldara og samræma.

\section{9. grein}

Samningsaðilar skulu samræma starfið að auknu umferðaröryggi.

\section{Samstarf á sviði umhverfisverndar (3)}

\section{0. grein (3)}

Samningsaðilar skulu í innlendri löggjöf og við beiting hennar svo sem framast er unnt leggja umhverfisverndarhagsmuni annarra samningsaðila að jöfnu við hagsmuni síns eigin lands á pví sviði.

\section{1. grein (3)}

Samningsaðilar skulu kappkosta að samhæfa umhverfisverndarreglur sínar í pví skyni að á verði komið sem mestu samræmi, að pví er varðar viðmiðunarmörk og meginreglur um losun úrgangs, notkun umhverfismengandi eiturefna og aðra umhverfisröskun.

\section{2. grein (3)}

Samningsaðilar skulu kappkosta að samhæfa ákvarðanir um náttúruverndar- og útivistarsvæði, svo og varðandi friðun og aðrar ráðstafanir til verndar jurtum og dýrum.

\section{Annaơ samstarf}

\section{3. grein (8)}

Pátttaka samningsaðila í evrópskri og annarri alpjóðlegri samvinnu hefur í för með sér góða samstarfskosti í págu ríkisborgara og fyrirtækja Norðurlanda. Í pessum efnum bera ríkisstjórnirnar sérstaka ábyrgð á pví að gæta sameiginlegra hagsmuna og sjónarmiða.

\section{4. grein}

Starfsmaður í utanríkispjónustu samningsaðila, er starfi gegnir utan Norðurlanda, skal að pví leyti sem pað samrýmist skyldustörfum hans og ekkert er til fyrirstöðu af hálfu pess ríkis, par sem hann starfar, aðstoða einnig ríkisborgara annarra Norðurlanda, hafi pau ekki fulltrúa á peim stað.

\section{5. grein}

Samningsaðilar skulu, hvenær sem pað telst kleift og hagkvæmt, samræma starfsemi sína til aðstoðar og samstarfs við próunarlöndin.

\section{6. grein}

Ráðstafanir í pví skyni að breiða út pekkingu á Norðurlöndum og norrænu samstarfi skulu gerðar í náinni samvinnu milli samningsaðila og stofnana peirra, sem annast landkynningu erlendis. Pegar hentugt pykir, geta aðilar komið fram sameiginlega.

\section{7. grein}

Samningsaðilar skulu vinna að pví, að samræmd verði opinber hagskýrslugerð íýmsum greinum.

\section{Sérstakir samningar (3)}

\section{8. grein (3)}

Nánari ákvæði um samstarfið á peim sviðum, sem hér voru talin, má setja í sérstökum samningum. 


\section{Tilhögun norræns samstarfs}

\section{9 grein (4)}

Norðurlönd skulu jafnan hafa samráð og gera ráðstafanir til samræmingar, pegar pörf krefur, til pess að framkvæma og efla norræna samvinnu samkvæmt samningi pessum eða öðrum.

\section{0. grein $(4,8)$}

Samstarfið fer fram í Norðurlandaráði, í ráðherranefnd Norðurlanda, á fundum forsætisráðherra, utanríkisráðherra og annarra ráðherra, í sérstökum samstarfsstofnunum og milli stjórnvalda landanna sem annast viðkomandi málaflokka.

\section{1. grein}

Ákvæði, sem til hefur orðið með samstarfi tveggja eða fleiri samningsaðila, má aðili ekki breyta nema hinum sé tilkynnt. Ekki verður pó krafizt tilkynningar, pegar mikið liggur á eða ákvæðið skiptir litlu máli.

\section{2. grein}

Yfirvöld á Norðurlöndum geta haft beint samband sín á milli í öðrum málum en peim, sem utanríkispjónustunni ber að fjalla um samkvæmt eðli peirra, eða af öðrum ástæðum.

\section{3. grein (3)}

Veita ber almenningi aðgang að upplýsingum um norræn samstarfsmálefni, svo sem framast er kostur.

\section{Norðurlandaráð (5)}

\section{4. grein $(5,2)$}

Í Norðurlandaráði starfa saman pjóðping Norðurlandanna ásamt landspingi Álandseyja, lögpingi Færeyja og landspingi Grænlands og ríkisstjórnir landanna ásamt stjórn Álandseyja og landsstjórnum Færeyja og Grænlands. Ráðið getur átt frumkvæði að lausn vandamála og verið ráðgefandi um vandamál sem varða samvinnu landanna, svo og Álandseyja, Færeyja og Grænlands, eða einhverra peirra. Að öðru leyti hefur ráðið á hendi verkefni sem af pessum samningi eða öðrum leiðir.

\section{5. grein (5)}

Ráðið getur sampykkt ályktun, beint tilmælum til eða látið i ljós álit við eina eða fleiri af ríkisstjórnum Norðurlanda eða ráðherranefndina.

\section{6. grein (5)}

Auk peirra málaflokka, sem sérstaklega er um samið, skal ráðið, pegar tími vinnst til, fá tækifæri til að tjá sig um mikilsverð efni norrænnar samvinnu.

47. grein $(5,2,8)$

Ráðið skipa 87 kjörnir fulltrúar, fulltrúar ríkisstjórnanna og fulltrúar stjórnar Álandseyja og landsstjórna Færeyja og Grænlands.

Pjóðping Danmerkur kýs 16 fulltrúa, ríkisping Finnlands 18 fulltrúa, Alpingi 7 fulltrúa, stórping Noregs og ríkisping Svípjóðar hvort um sig 20 fulltrúa og lögping Álandseyja og Færeyja og landsping Grænlands 2 fulltrúa hvert. Enn fremur kýs hvert ping jafnmarga varamenn.

Kjör fulltrúa og varamanna fer fram árlega og gildir til næsta kjörs. Við kjör skal pess gætt að mismunandi stjórnmálastefnur eigi fulltrúa í ráðinu.

Kjörgengir eru einvörðungu pingmenn á pví pingi par sem kjör fer fram.

Ríkisstjórnirnar, stjórn Álandseyja og landsstjórnir Færeyja og Grænlands velja úr sínum hópi stjórnarfulltrúa, svo marga sem pær óska.

\section{8. grein $(5,2,8,9)$}

Í deild danska ríkisins eru peir fulltrúar sem pjóðpingið kýs og peir fulltrúar sem ríkisstjórnin velur, svo og deildir Færeyja og Grænlands sem nefndar eru í 2. mgr. Í deild 
Finnlands eru peir fulltrúar, sem ríkispingið kýs og peir fulltrúar sem ríkisstjórnin velur, svo og deild Álandseyja sem talin er í 2. mgr. Deildir hinna ríkjanna skipa kjörnir fulltrúar pjóðpinganna og fulltrúar sem ríkisstjórnirnar velja.

Í deild Færeyja eru peir fulltrúar sem lögpingið kýs og peir fulltrúar sem landsstjórnin velur. Í deild Grænlands eru peir fulltrúar sem landspingið kýs og peir fulltrúar, sem landsstjórnin velur. Í deild Álandseyja eru peir fulltrúar sem lögpingið kýs og peir fulltrúar sem stjórn Álandseyja velur.

Orðið „deild" í 2. mgr. 58. gr. merkir deild viðkomandi lands.

\section{9. grein $(5,2)$}

Fulltrúar ríkisstjórnanna og fulltrúar stjórnar Álandseyja og landsstjórna Færeyja og Grænlands eiga ekki atkvæðisrétt í ráðinu.

Um málefni sem einvörðungu varða túlkun samninga milli einstakra landa eiga ekki aðrir atkvæðisrétt en fulltrúar peirra landa.

\section{0. grein (5)}

Stjórnpættir ráðsins eru: ping ráðsins, stjórnarnefnd og nefndir.

\section{1. grein $(5,7,9)$}

Ping Norðurlandaráðs skipa allir fulltrúar ráðsins.

Reglulegt ping er háð einu sinni á ári hið minnsta. Til aukapings eða pings um sérstakt málefni skal kvatt, pegar stjórnarnefndin ákveður eða pegar að minnsta kosti tvær ríkisstjórnir eða eigi færri en 25 kjörnir fulltrúar æskja pess.

Vald ráðsins er í höndum pingins, nema annað sé ákveðið.

Pingfundir eru háðir í heyranda hljóði, nema pingið ákveði annað.
52. grein $(5,6,7,9)$

Á árlegu reglulegu pingi Norðurlandaráðs kýs pað stjórnarnefnd til eins almanaksárs í senn, sem í eiga sæti forseti ásamt peim fjölda annarra fulltrúa, sem pingsköp Norðurlandaráðs kveða á um.

Pess skal gætt að mismunandi stjórnmálastefnur eigi fulltrúa í stjórnarnefndinni. Sérhvert land skal eiga fulltrúa í stjórnarnefndinni.

Fulltrúi í stjórnarnefndinni skal vera kjörinn fulltrúi í ráðinu.

Stjórnarnefndin annast dagleg störf ráðsins og er að öðru leyti fulltrúi pess í samræmi við samning pennan og pingsköp ráðsins.

Embætti forseta ráðsins færist milli landanna með peim hætti sem fram kemur í pingsköpum Norðurlandaráðs.

\section{3. grein $(5,9)$}

Pingið ákveður fjölda nefnda og starfssvið peirra. Verkefni nefndanna er að undirbúa afgreiðslu mála í ráðinu.

\section{4. grein $(5,6,7,9)$}

Ráðinu til aðstoðar í störfum sínum er skrifstofa stjórnarnefndarinnar.

\section{5. grein $(5,2,7,9)$}

Sérhver ríkisstjórn, landsstjórnir Færeyja og Grænlands, stjórn Álandseyja, ráðherranefndin, stjórnarnefnd ráðsins og nefndirnar svo og sérhver fulltrúi hefur tillögurétt í ráðinu.

\section{6. grein $(5,7)$}

Pingið gerir ályktun á grundvelli tillögu sem fram hefur komið.

Stjórnarnefndinni er rétt að bera fram önnur tilmæli á grundvelli tillögu sem fram hefur komið. Pingið leggur fram álit sitt. Pegar stjórnarnefndin ber fram tilmæli leggur hún fram álit sitt. 
Stjórnarnefndin skal tilkynna pinginu pær ráðstafanir sem gerðar hafa verið samkvæmt 2. og 3. mgr.

\section{7. grein $(5,7)$}

Kjörinn fulltrúi getur beint fyrirspurn til ríkisstjórnar eða ráðherranefndarinnar vegna skýrslu eða greinargerðar sem send hefur verið ráðinu eða um önnur mál sem varða norræna samvinnu.

\section{8. grein $(5,2,7)$}

Hver deild ber kostnað af pátttöku sinni í ráðinu.

Stjórnarnefndin ákveður fyrir hvert fjárhagsár hvernig sameiginlegur kostnaður skiptist milli deildanna.

\section{9. grein (5)}

Pingið setur ráðinu pingsköp. Til sampykktar á starfsreglum eða til breytingar á peim parf sampykki tveggja priðju hluta kosinna fulltrúa ráðsins.

\section{Ráơherranefnd Norðurlanda (5)}

\section{0. grein $(5,2)$}

Í ráðherranefnd Norðurlanda starfa ríkisstjórnir landanna saman.

Stjórn Álandseyja og landsstjórnir Færeyja og Grænlands taka pátt í starfi ráðherranefndarinnar.

Ráðherranefndin tekur ákvarðanir að pví marki sem mælt er fyrir um í samningi pessum og öðrum samningum milli Norðurlandanna. Ráðherranefndin skal og annast samvinnu í öðrum samstarfsmálum ríkisstjórna Norðurlanda innbyrðis og ríkisstjórnanna og Norðurlandaráðs.

\section{1. grein $(5,1,2,8)$}

Í undantekningartilvikum getur staðgengill með umboði sótt fund í stað fulltrúa úr ríkisstjórn, stjórn Álandseyja eða lands- stjórnum Færeyja eða Grænlands. Pó verða hverju sinni fulltrúar priggja ríkja hið fæsta að vera ráðherrar.

Forsætisráðherrar hafa í hendi yfirstjórn samræmingar norræns samstarfs. Hvert ríki tilnefnir sérstakan ráðherra (samstarfsráðherra) svo og aðstoðarmann ráðherra eða embættismann (fulltrúa í norrænu samstarfsnefndinni) forsætisrádherra til aðstoðar.

Ríkisstjórnir Norðurlanda fara með formennsku til skiptis samkvæmt nánara samkomulagi. Landi pví, sem fer með formennsku hverju sinni, ber að samræma norrænt samstarf ríkisstjórnanna og taka nauðsynlegt frumkvæði par að lútandi. pað veitir ráðherranefndinni forystu svo og öðrum ráðherrafundum og hefur forystu um samráð ríkisstjórnanna um evrópsk og önnur alpjóðleg málefni á öllum stigum.

Til aðstoðar ráðherranefndinni við störf hennar eru embættismannanefndir og skrifstofa ráðherranefndarinnar.

\section{2. grein (5)}

Ráðherranefndin er ákvörðunarhæf, pegar fulltrúar frá öllum löndunum taka pátt í störfum hennar. Pegar einvörðungu er rætt um málefni einstakra landa, er pó nægjanlegt, að aðeins fulltrúar peirra landa starfi í nefndinni.

Sérhvert land fer með eitt atkvæði í ráðherranefndinni.

Ákvarðanir ráðherranefndarinnar skulu sampykktar samhljóða. Í málum, sem varða pingsköp, nægir pó einfaldur meiri hluti atkvæða til ákvörðunar. Séu atkvæði jöfn, ræður atkvæði formanns úrslitum.

Ákvörðun er gild, pótt einhver fulltrúi greiði, ekki atkvæði.

\section{3. grein $(5,2,8)$}

Ákvarðanir ráðherranefndarinnar eru bindandi fyrir hvert land. Ákvörðun í máli sem sam- 
kvæmt stjórnarskrá einhvers landanna krefst sampykkis pjóðpings pess lands er pó ekki bindandi fyrir pað land fyrr en pjóðping pess hefur sampykkt ákvörðunina. Sé slíkrar sampykktar krafist skal ráðherranefndinni skýrt frá pví áður en hún tekur ákvörðun. Önnur lönd eru ekki heldur bundin af slíkri ákvörðun fyrr en sampykkt pjóðpingsins liggur fyrir.

Ákvörðun sem tekin er samkvæmt samningi pessum er bindandi fyrir Álandseyjar, Færeyjar og Grænland í peim mæli sem pau lönd fallast á ákvörðunina í samræmi við sjálfstjórnarreglur.

\section{4. grein $(5,6,8)$}

Ráðherranefndin gefur Norðurlandaráði skýrslu árlega um norrænt samstarf og leggur fram greinargerð um áætlanir um áframhaldandi samstarf.

Forsætisráðherra pess lands, sem fer með formennsku, gerir Norðurlandaráði grein fyrir meginatriðum samstarfsins svo og samstarfi ríkisstjórnanna um evrópsk og önnur albjóðleg málefni.

Ráðherranefnd Norðurlanda ber að leggja fyrir Norðurlandaráð til umsagnar tillögu sína að fjárhagsáætlun.

Norðurlandaráð getur lagt til breytta forgangsröðun verkefna innan peirra fjárhagsmarka sem ráðherranefndin hefur sett.

Sé ekki hægt að tilgreina sérstakar ástæður ber ráðherranefndinni að fara að tillögum ráðsins pegar um er að ræða fjárveitingar innan gefinna fjárhagsmarka.

\section{5. grein (5)}

Ráðherranefndin skal fyrir hvert aðalping Norðurlandaráðs skýra ráðinu frá peim ráðstöfunum, sem gerðar hafa verið samkvæmt ályktunum og tilmælum ráðsins. Ef ályktun eða tilmælum er beint til einnar ríkisstjórnar eða fleiri, getur hlutaðeigandi ríkisstjórn eða ríkisstjórnir gefið slíka skýrslu.
66. grein (5)

Ráðherranefndin setur sér starfsreglur.

\section{7. grein (5)}

Auk samstarfs milli ríkisstjórna Norðurlanda í ráoherranefndinni geta pær átt samstarf á ráðherrafundum Norðurlanda.

\section{Breytingar á samningnum (5)}

\section{8. grein (5)}

Áður en löndin koma sér saman um breyting á samningi pessum, skal gefa Norðurlandaráði kost á að láta i ljós álit sitt.

\section{Lokaákvæði}

\section{Lokaákvörơun um samninginn}

23. mars 1962

\section{9. grein}

Samning pennan skal fullgilda og senda fullgildingarskjölin hið fyrsta til finnska utanríkisráduneytisins.

Samningurinn tekur gildi fyrsta dag bess mánaðar, sem næstur kemur eftir pann dag, er borizt hafa fullgildingarskjöl allra aðila.

\section{0. grein}

Eski samningsaðili að segja upp samningnum, skal skrifleg tilkynning um pað send finnsku stjórninni, sem ber pá pegar að skýra hinum samningsaðilunum frá pessu og hvaða dag tilkynningin hafi borizt.

Uppsögnin tekur aðeins til pess lands, sem hana hefur sent, og hún öðlast gildi frá og með fyrsta degi pess mánaðar, sem næstur kemur sex mánuðum eftir að finnsku stjórninni barst uppsagnartilkynningin.

Samningurinn skal geymdur í skjalasafni finnska utanríkisráðuneytisins og skal finnska utanríkisráðuneytið senda hverjum aðila staðfest afrit.

Til staðfestingar pessu hafa neðanskráðir fulltrúar, sem til pess hafa umboð, undirritað pennan samning. 
Gjört í Helsingfors í einu eintaki á hverju máli: dönsku, finnsku, íslensku, norsku og sænsku, og skulu peir textar allir jafngildir. Hinn tuttugsta og priðja marz nítján hundruð sextiu og tvö.

\section{$[\ldots]$}

\section{Lokaákvörơun um samninginn}

\section{3. febrúar 1971}

Samning bennan skal fullgilda og senda fullgildingarskjölin hið fyrsta til utanríkisráðuneytis Finnlands.

Samningurinn skal geymdur í utanríkisráðuneyti Finnlands, og skal ráðuneytið senda hverjum samningsaðila staðfest afrit.

Samningurinn öðlast gildi prjátíu dögum eftir að fullgildingarskjöl allra samningsaðila hafa borizt.

pessu til staðfestingar hafa neðanskráðir fulltrúar, sem til pess hafa umboð, undirritað samning pennan í Kaupmannahöfn 13. febrúar 1971, í einu eintaki á hverju máli: dönsku, finnsku, íslenzku, norsku og sænsku, og skulu peir textar allir jafngildir.

$[\ldots]$

\section{Lokaákvörðun um samninginn}

\section{1. mars 1974}

Samkomulag petta skal fullgilda, og skulu fullgildingarskjölin svo skjótt sem við verður komið afhent utanríkisráðuneyti Finnlands til varðveislu.

Samkomulagið skal varðveitt í utanríkisráðuneyti Finnlands, og skal pað ráðuneyti láta hverjum samningsaðila í té staðfest afrit.

Samkomulagið öðlast gildi prjátíu dögum eftir að fullgildingarskjöl allra samkomulagsaðila hafa borist.

pessu til staðfestu hafa undirritaðir fulltrúar, er til pess höfðu umboð, undirritað samkomulag petta í Kaupmannahöfn hinn 11. mars 1974 í einu eintaki á dönsku, finnsku, íslensku, norsku og sænsku, og skulu peir textar allir jafngildir.

[...]

\section{Lokaákvörơun um samninginn}

15. júní 1983

Samkomulag petta skal fullgilda, og skulu fullgildingarskjölin svo skjótt sem við verður komið afhent utanríkisráðuneyti Finnlands til varðveislu, og skal pað ráðuneyti láta hverjum samningsaðila í té staðfest afrit samkomulagsins.

Samkomulagið öðlast gildi prjátíu dögum eftir að fullgildingarskjöl allra samkomulagsaðila hafa borist.

Pessu til staðfestu hafa undirritaðir fulltrúar, er til pess höfðu umboð, undirritað samkomulag petta í Reykjavík 15. júní 1983 í einu eintaki á dönsku, finnsku, íslensku, norsku og sænsku, og skulu peir textar allir jafngildir. [...]

\section{Lokaákvörơunin um samninginn}

6. maí 1985

Samkomulagið öðlast gildi prjátíu dögum eftir pann dag sem allir samningsaðilar hafa tilkynnt finnska utanríkisráðuneytinu að pær ráðstafanir hafi verið gerðar sem nauðsynlegar eru til pess að pað geti öðlast gildi.

Finnska utanríkisráðuneytið skal tilkynna hverjum samningsaðila um dagsetningar á móttöku slíkra tilkynninga.

Frumeintak pessa samkomulags skal geymt i finnska utanríkisráduneytinu sem lætur samningsaðilum í té staðfest eftirrit af pví.

Pessu til staðfestu hafa fulltrúar, sem til pess hafa umboð, undirritað samkomulag petta.

Gjört í Lundi 6. maí 1985 í einu eintaki á dönsku, finnsku, íslensku, norsku og sænsku, og skulu peir textar allir jafngildir.

[...]

\section{Lokaákvörơun um samninginn}

21. ágúst 1991

Samkomulagið öðlast gildi 30 dögum eftir pann dag er allir aðilar hafa tilkynnt finnska utanríkisráðuneytinu að peir hafi sampykkt pað. 
Finnska utanríkisráðuneytið tilkynnir öðrum aðilum um móttöku pessara tilkynninga og um pað hvenær samkomulagið tekur gildi.

Frumriti pessa samkomulags skal komið til vörslu hjá finnska utanríkisráðuneytinu sem skal senda staðfest afrit af pví til hinna aðilanna.

Pessu til staðfestu hafa undirritaðir fulltrúar, sem til pess hafa fullt umboð, undirritað samkomulag petta.

Gjört í Tammerfors 21. ágúst 1991 í einu eintaki á dönsku, finnsku, íslensku, norsku og sænsku og skulu allir textar jafngildir.

[...]

\section{Lokaákvörðun um samninginn}

18. mars 1993

Samkomulagið öðlast gildi 30 dögum eftir pann dag er allir aðilar hafa tilkynnt finnska utanríkisráðuneytinu að peir hafi sampykkt pað.

Finnska utanríkisráðuneytið tilkynnir öðrum aðilum um móttöku pessara tilkynninga og um pað hvenær samkomulagið tekur gildi.

Frumriti pessa samkomulags skal komið til vörslu hjá finnska utanríkisráduneytinu sem skal senda staðfest afrit af pví til hinna aðilanna.

Pessu til staðfestu hafa undirritaðir fulltrúar, sem til pess hafa fullt umboð, undirritað samkomulag petta.

Gjört í Helsingfors 18. mars 1993 í einu eintaki á dönsku, finnsku, íslensku, norsku og sænsku og skulu allir textar jafngildir.

[...]

\section{Lokaákvörð̃un um samninginn}

\section{9. september 1995}

Samkomulag petta öðlast gildi fimmtán dögum eftir pann dag er allir samningsaðilar hafa tilkynnt finnska utanríkisráouneytinu, að peir hafi sampykkt pað.

Finnska utanríkisráðuneytið tilkynnir hinum samningsaðilunum um móttöku tilkynninga skv. ofansögðu og hvenær samkomulagið taki gildi.

Frumriti pessa samkomulags skal komið til vörslu hjá finnska utanríkisráðuneytinu sem lætur öðrum samningsaðilum í té staðfest afrit af pví.

Pessu til staðfestu hafa fulltrúar, sem til pess hafa fullt umboð, undirritað samkomulag petta.

Gjört í Kaupmannahöfn hinn 29. september 1995 í einu eintaki á dönsku, finnsku, íslensku, norsku og sænsku og skulu allir textar jafngildir.

[...] 


\section{Skýringar}

1 Nýr texti 1974.

2 Nýr texti 1983.

3 Greinin kom 1974.

4 Nýr texti 1971.

5 Greinin kom 1971.

6 Nýr texti 1985.

7 Nýr texti 1991.

8 Nýr texti 1993.

9 Nýr texti 1995. 


\section{Helsingforsavtalen}

Samarbeidsavtale mellom Danmark, Finland, Island, Norge og Sverige

(Helsingforsavtalen).

Avtalen ble undertegnet den 23. mars 1962 og trådte i kraft den 1 . juli samme år. Den opprinnelige tekst er revidert ved avtaler som ble undertegnet den 13. februar 1971, den 11. mars 1974, den 15. juni 1983, den 6. mai 1985, den 21. august 1991, den 18. mars 1993 og den 29. september 1995. Den sistnevnte endringsavtale trådte i kraft den 2. januar 1996.

\section{Preambel til overenskomsten}

\section{3. mars 1962}

Danmarks, Finnlands, Islands, Norges og

Sveriges regjeringer

som ønsker å fremme ytterligere det nære fellesskap som råder mellom de nordiske folk med hensyn til kultur og når det gjelder rettsog samfunnsoppfatning, og ytterligere utvikle samarbeidet mellom de nordiske land;

som ønsker å gjennomføre ensartede bestemmelser i de nordiske land i så mange henseende som mulig;

som på alle områder hvor det finnes forutsetninger for det, vil søke å oppnå en hensiktsmessig arbeidsdeling mellom landene;

som vil fortsette det for landene betydningsfulle samarbeid innen Nordisk Råd og andre samarbeidsorganer;

er blitt enige om følgende bestemmelser:

\section{Preambel til overenskomsten}

\section{3. februar 1971}

Danmarks, Finlands, Islands, Norges og

Sveriges regjeringer, som vil styrke og ytterligere utbygge det institusjonelle grunnlag for samarbeidet mellom de nordiske land,

som finner det formålstjenlig med dette for øye å endre samarbeidsavtalen av 23. mars 1962 mellom de nordiske land,

som derfor har besluttet å ta med i samarbeidsavtalen de grunnleggende bestemmelser om Nordisk Råd,

som videre har besluttet å ta med i samarbeidsavtalen bestemmelser om et nordisk ministerråd med myndighet for hele det nordiske samarbeidsfelt, er blitt enige om følgende:

\section{Preambel til overenskomsten}

\section{1. mars 1974}

Danmarks, Finlands, Islands, Norges og

Sveriges regjeringer, som gjennom avtalen av 13. februar 1971 endret samarbeidsavtalen mellom de nordiske land av 23. mars 1962,

som finner det formålstjenlig å gjøre visse ytterligere endringer i og tillegg til avtalen, er blitt enige om følgende:

\section{Preambel til overenskomsten}

\section{5. juni 1983}

Danmarks, Finlands, Islands, Norges og

Sveriges regjeringer,

som ved avtaler av 13. februar 1971 og 11. mars 1974 har endret samarbeidsavtalen av 23. mars 1962 mellom de nordiske land, som finner det formålstjenlig å foreta visse endringer i avtalen for å gi Færøyene og Åland en utvidet representasjon i Nordisk Råd og Nordisk Ministerråd samt for å gi Grønland samme representasjon i disse organer, er blitt enige om følgende: 
Preambel til overenskomsten

\section{6. mai 1985}

Danmarks, Finlands, Islands, Norges

og Sveriges regjeringer,

som gjennom overenskomster av 13.

februar 1971, 11. mars 1974 og 15. juni 1983

har endret samarbeidsavtalen av 23. mars

1962 mellom de nordiske land og

som ønsker å effektivisere det nordiske

samarbeids arbeidsformer,

er blitt enige om følgende:

\section{Preambel til overenskomsten}

\section{1. august 1991}

Danmarks, Finlands, Islands, Norges og

Sveriges regjeringer,

som ved overenskomster av 13. februar

1971, 11. mars 1974, 15. juni 1983 og 6. mai

1985 har endret samarbeidsavtalen av

23. mars 1962 mellom de nordiske land, og som finner det formålstjenlig med visse

endringer av Nordisk Råds organisasjon og arbeidsformer, er blitt enige om følgende:

\section{Preambel til overenskomsten}

\section{8. mars 1993}

Danmarks, Finlands, Islands, Norges og

Sveriges regjeringer,

som ved overenskomster av 13. februar

1971,11 . mars 1974,15 . juni 1983,6 . mai

1985 og 21. august 1991 har endret sam-

arbeidsoverenskomsten av 23. mars 1962

mellom de nordiske land, og som ønsker å fornye og utvikle det nordiske samarbeidet i lys av de nordiske lands utvidede deltakelse i europeisk samarbeid, er blitt enige om følgende:

\section{Preambel til overenskomsten}

29. september 1995

Danmarks, Finlands, Islands, Norges og Sveri-

ges regjeringer,

som ved overenskomster av 13. februar

1971,11 . mars 1974,15 . juni 1983,6 . mai
1985, 21. august 1991 og 18. mars 1993

har endret samarbeidsoverenskomsten av

23. mars 1962 mellom de nordiske land, og som ønsker å fornye og utvikle det nordiske samarbeidet ytterligere i lys av de nordiske lands utvidede deltakelse i europeisk samarbeid,

er blitt enige om følgende:

\section{Innledende bestemmelse}

\section{Artikkel $1(1,8)$}

Avtalepartene skal søke å bevare og ytterligere utvikle samarbeidet mellom landene på det rettslige, kulturelle, sosiale og økonomiske området, og når det gjelder samferdsel og miljøvern.

Avtalepartene bør rådføre seg med hverandre i spørsmål av felles interesse som behandles i europeiske og andre internasjonale organisasjoner og konferanser.

\section{Rettslig samarbeid}

\section{Artikkel 2 (9)}

Ved utformingen av lover og andre rettsregler i de nordiske land skal statsborgere i de øvrige nordiske land behandles likt med landets egne statsborgere. Dette gjelder innenfor samarbeidsoverenskomstens virkeområde.

Det kan likevel gjøres unntak fra første avsnitt dersom krav til statsborgerskap er grunnlovsfestet, nødvendig på grunn av andre internasjonale forpliktelser eller det ellers av særlige grunner anses som nødvendig.

\section{Artikkel 3}

Avtalepartene skal søke å lette adgangen for statsborgere i et nordisk land til å oppnå statsborgerskap i et annet nordisk land.

\section{Artikkel 4}

Avtalepartene skal fortsette lovsamarbeidet i den hensikt å oppnå størst mulig overensstemmelse på privatrettens område. 


\section{Artikkel 5}

Avtalepartene bør søke å oppnå ensartede bestemmelser om forbrytelser og deres rettslige følger.

Forbrytelser begått i et nordisk land bør i størst mulig utstrekning kunne etterforskes og være gjenstand for rettergang og pådømmelse også $i$ et annet nordisk land.

\section{Artikkel 6}

Avtalepartene skal søke å oppnå innbyrdes samordning av annen lovgivning enn den som her er nevnt på områder der det synes hensiktsmessig.

\section{Artikkel 7}

Hver avtalepart bør søke å få gjennomført bestemmelser som medfører at beslutning av domstol eller annen myndighet $\mathrm{i}$ et annet nordisk land kan iverksettes også innen partens område.

\section{Kulturelt samarbeid}

\section{Artikkel 8 (2)}

Undervisningen og utdannelsen i skolene i de nordiske land skal i passende omfang omfatte undervisning om språk, kultur og alminnelige samfunnsforhold i de øvrige nordiske land, herunder Færøyene, Grønland og Åland.

\section{Artikkel 9}

Hver avtalepart bør opprettholde og utvide mulighetene for studerende hjemmehørende $i$ et annet nordisk land til å studere og avlegge eksamen ved dens læresteder. I størst mulig utstrekning bør deleksamen avlagt i et nordisk land kunne anerkjennes og medregnes ved slutteksamen i et annet nordisk land.

$\varnothing$ konomisk støtte fra hjemlandet bør kunne ytes uten hensyn til i hvilket land studiene finner sted.

\section{Artikkel 10}

Avtalepartene bør samordne slik offentlig anordnet utdannelse som tar sikte på å gi rett til særskilt yrkesutøvelse.

Denne utdannelse bør så vidt mulig gi samme rett til yrkesutøvelse i alle nordiske land. Det kan likevel stilles krav om slik tilleggsutdannelse som nasjonale forhold måtte tilsi.

\section{Artikkel 11}

På de områder der det er hensiktsmessig bør utbyggingen av læresteder samordnes gjennom stadig samarbeid om utbyggingsplanene og deres gjennomføring.

\section{Artikkel 12}

Samarbeid på forskningens område bør være ordnet slik at tilgjengelige bevilgninger og andre ressurser samordnes og utnyttes best mulig, bl.a. ved at det opprettes felles institusjoner.

\section{Artikkel 13}

For å støtte og styrke den kulturelle utviklingen skal de kontreherende parter fremme det frie nordiske folkeopplysningsarbeidet og utvekslingen innenfor litteratur, kunst, musikk, teater, film og de øvrige kulturområder, hvorunder blandt annet de muligheter radio og televisjon byr på bør utnyttes.

\section{Sosialt samarbeid}

\section{Artikkel 14}

Avtalepartene skal søke å bevare og ytterligere utvikle det fellesnordiske arbeidsmarkedet etter de retningslinjer som er trukket opp i tidligere avtaler. Arbeidsformidling og yrkesveiledning skal samordnes. Det skal være fri utveksling av praktikanter.

Ensartet utforming av nasjonale regler om arbeidervern og lignende spørsmål skal søkes oppnådd. 


\section{Artikkel 15}

Avtalepartene skal arbeide for at en statsborger $i$ et nordisk land under opphold $i$ et annet nordisk land i størst mulig utstrekning skal nyte godt av de sosiale goder som ytes i oppholdslandet til dets egne statsborgere.

\section{Artikkel 16}

Avtalepartene skal ytterligere utvikle samarbeidet innen helsevesenet, sykepleien, alkoholistbehandlingen og når det gjelder barne- og ungdomsvern.

\section{Artikkel 17}

Hver avtalepart skal arbeide for at medisinsk, teknisk eller annen lignende sikkerhetskontroll blir utført på en slik måte at attest eller bevitnelse om kontrollen kan godtas i de øvrige nordiske land.

\section{Økonomisk samarbeid}

\section{Artikkel 18}

For å fremme det nordiske økonomiske samarbeid på forskjellige områder skal avtalepartene rådføre seg med hverandre om den økonomiske politikk. Herunder bør oppmerksomheten rettes mot mulighetene for å samordne tiltak som treffes med sikte på konjunkturutjevning.

\section{Artikkel 19}

Avtalepartene har til hensikt så langt det er mulig å fremme et produksjons- og investeringssamarbeid mellom sine land og herunder søke å legge forholdene til rette for direkte samarbeid mellom foretagender $\mathrm{i}$ to eller flere av de nordiske land. Avtalepartene bør som ledd $\mathrm{i}$ et videre internasjonalt samarbeid søke å oppnå en hensiktsmessig arbeidsdeling mellom landene når det gjelder produksjon og investeringer.

\section{Artikkel 20}

Avtalepartene skal arbeide for størst mulig frihet for kapitalbevegelser mellom de nordiske land. Når det gjelder andre betalings- og valutaspørsmål av felles interesse bør det søkes oppnådd felles løsninger.

\section{Artikkel 21}

Avtalepartene skal søke å befeste det samarbeid som tidligere er innledet for å fjerne hindringer for handelen mellom de nordiske landene, og så langt som mulig ytterligere styrke og utvikle dette samarbeid.

\section{Artikkel 22}

Avtalepartene skal i internasjonale handelspolitiske spørsmål såvel hver for seg som i fellesskap søke å fremme nordiske interesser, og rådføre seg med hverandre i dette øyemed.

\section{Artikkel 23}

Avtalepartene skal arbeide for en samordning av de tolltekniske og tolladministrative bestemmelser og for slike tollmessige forenklinger som kan lette samferdselen mellom landene.

\section{Artikkel 24}

Bestemmelsene vedrørende den nordiske grensehandel skal utformes på en slik måte at befolkningen i grensetraktene påføres minst mulig ulemper.

\section{Artikkel 25}

Når det foreligger behov og forutsetninger for felles økonomisk utbygging av områder innen to eller flere avtaleparters territorier som grenser opp til hverandre, skal disse parter i fellesskap søke å fremme en slik utbygging.

\section{Samarbeid på samferdselens område}

\section{Artikkel 26}

Avtalepartene skal arbeide for å befeste det samarbeid som tidligere er innledet på samferdselens område, og søke å utvikle dette samarbeidet for å lette forbindelsene og vare- 
byttet mellom landene og oppnå hensikts-

messige løsninger på de problemer som måtte forekomme på dette område.

\section{Artikkel 27}

Bygging av samferdselsforbindelser som berører to eller flere avtaleparters område skal skje i samråd mellom de berørte parter.

\section{Artikkel 28}

Avtalepartene skal søke å bevare og utvikle ytterligere det samarbeid som har ført til at deres territorier utgjør ett passkontrollområde. Kontrollen av reisende som passerer grense mellom nordiske land skal også ellers forenkles og samordnes.

\section{Artikkel 29}

Avtalepartene skal samordne arbeidet for $ø k t$ trafikksikkerhet.

\section{Samarbeid på miljøvernområdet (3)}

Artikkel 30 (3)

Avtalepartene skal i sin nasjonale lovgivning og ved anvendelsen av denne i størst mulig utstrekning likestille de øvrige avtalepartenes miljøverninteresser med sitt eget lands.

\section{Artikkel 31 (3)}

Avtalepartene skal søke å harmonisere sine miljøvernregler i den hensikt å oppnå den størst mulige overensstemmelse når det gjelder normer og retningslinjer for utslipp av forurensninger, anvendelse av miljøgifter og andre forstyrrelser av miljøet.

\section{Artikkel 32 (3)}

Avtalepartene skal tilstrebe samordning når det gjelder å reservere naturvern- og friluftsområder samt når det gjelder fredning og andre forholdsregler for vern av planter og dyr.

\section{Annet samarbeid}

\section{Artikkel 33 (8)}

Avtalepartenes deltakelse i europeisk og annet internasjonalt samarbeid gir gode muligheter for samarbeid til fordel for nordiske statsborgere og foretak. Regjeringene har i denne sammenheng et spesielt ansvar for å ivareta felles interesser og synspunkter.

\section{Artikkel 34}

Tjenestemann som tilhører en avtaleparts utenrikstjeneste og tjenestegjør utenfor de nordiske land, skal, i den utstrekning det er forenlig med hans tjenesteplikter og ikke møter hindringer fra det lands side hvor han tjenestegjør, også bistå statsborgere fra et annet nordisk land når dette ikke har noen representasjon på vedkommende sted.

\section{Artikkel 35}

Avtalepartene bør, når det finnes mulig og hensiktsmessig, samordne sin virksomhet for bistand til og samarbeid med utviklingslandene.

\section{Artikkel 36}

Tiltak for å spre økt kjennskap til de nordiske land og det nordiske samarbeidet bør foregå i nært samarbeid mellom avtalepartene og deres organer for informasjon til utlandet. Der det finnes hensiktsmessig, kan felles opptreden komme på tale.

\section{Artikkel 37}

Avtalepartene skal arbeide for at forskjellige områder av den offentlige statistikk samordnes.

\section{Særlige avtaler (3)}

\section{Artikkel 38 (3)}

Nærmere regler om samarbeidet innenfor de her angitte områder skal kunne fastsettes i særlige avtaler. 


\section{Formene for nordisk samarbeid}

Artikkel 39 (4)

For å gjennomføre og videreutvikle det nordiske samarbeid etter denne og andre avtaler bør de nordiske land stadig samrå seg med hverandre, og treffe de samordningstiltak som det er behov for.

Artikkel $40(4,8)$

Samarbeidet finner sted i Nordisk Råd, i Nordisk Ministerråd, i statsministrenes, utenriksministrenes og i andre ministres møter, i særlige samarbeidsorganer og mellom landenes fagmyndigheter.

\section{Artikkel 41}

En bestemmelse som er et resultat av samarbeid mellom to eller flere avtaleparter må ikke endres av en part med mindre de øvrige parter underrettes om det. Underretning er ikke nødvendig i tilfelle hvor det haster og når det gjelder bestemmelser av mindre betydning.

\section{Artikkel 42}

Myndighetene i de nordiske land skal kunne korrespondere direkte med hverandre i slike saker som ikke etter sin natur eller av andre grunner bør behandles gjennom utenrikstjenesten.

\section{Artikkel 43 (3)}

I det nordiske samarbeidet bør det foreligge den størst mulige offentlighet.

\section{Nordisk Råd (5)}

\section{Artikkel $44(5,2)$}

I Nordisk Råd samarbeider de nordiske land samt Færøyenes, Grønlands og Ålands folkevalgte forsamlinger, landenes regjeringer samt Færøyenes og Grønlands landsstyrer og Ålands landskapsstyrelse. Rådet kan ta initiativ og gi råd i spørsmål som angår sam- arbeid mellom alle eller noen av disse land og Færøyene, Grønland og Åland, og har for øvrig de oppgaver som fremgår av denne og andre avtaler.

\section{Artikkel 45 (5)}

Rådet kan vedta rekommandasjoner og rette andre henvendelser eller avgi uttalelser til en eller flere av de nordiske lands regjeringer eller til ministerrådet.

\section{Artikkel 46 (5)}

Rådet bør, ut over hva som særlig er avtalt, gis anledning til å uttale seg om nordiske samarbeidsspørsmål av større betydning når dette ikke er umulig på grunn av tidsnød.

\section{Artikkel $47(5,2,8)$}

Rådet består av 87 valgte medlemmer, regjeringsrepresentanter og representanter for Færøyenes og Grønlands landsstyrer og Ålands landskapsstyrelse.

Av medlemmene velger Danmarks folketing 16, Finlands riksdag 18, Islands alting 7 og Norges storting og Sveriges riksdag hver 20, samt Færøyenes lagting, Grønlands landsting og Ålands lagting hver 2. Videre velger hver forsamling et tilsvarende antall suppleanter.

Valg av medlemmer og suppleanter foretas årlig og gjelder for tiden inntil neste valg. Ved valgene skal forskjellige politiske meningsretninger gis representasjon i Rådet.

Bare medlemmer av den forsamling som har foretatt valget kan være valgt medlem eller suppleant i Rådet.

Regjeringene, landsstyrene og landskapsstyrelsen utpeker blant sine medlemmer det antall representanter som de ønsker.

Artikkel 48 (5,2,8,9)

Danmarks rikes delegasjon består av de medlemmer som er valgt av folketinget og de representanter som er utpekt av regjeringen samt av Færøyenes og Grønlands delegasjo- 
ner som nevnt i annet avsnitt. Finlands delegasjon består av medlemmer som er valgt av riksdagen og de representanter som er utpekt av regjeringen samt av Ålands delegasjon nevnt i annet avsnitt. Delegasjonen for hvert av de øvrige land består av de medlemmer som er valgt av den folkevalgte forsamling og de representanter som er utpekt av regjeringen.

Færøyenes delegasjon består av de medlemmer som er valgt av lagtinget og de representanter som er utpekt av landsstyret. Grønlands delegasjon består av de medlemmer som er valgt av landstinget og de representanter som er utpekt av landsstyret. Ålands delegasjon består av de medlemmer som er valgt av lagtinget og de representanter som er utpekt av landskapsstyrelsen.

Med "delegasjon» forstås i artikkel 58, annet avsnitt, landets delegasjon.

\section{Artikkel $49(5,2)$}

Regjeringenes samt landsstyrenes og landskapsstyrelsens representanter har ikke stemmerett i rådet.

I spørsmål som angår anvendelsen av avtaler mellom enkelte land, har bare medlemmer fra disse land stemmerett.

\section{Artikkel $\mathbf{5 0}$ (5)}

Rådets organer er plenarforsamlingen, presidiet og utvalgene.

Artikkel $\mathbf{5 1}(5,7,9)$

Plenarforsamlingen består av alle medlemmer i Rådet.

Plenarforsamlingen avholder ordinær sesjon minst en gang i året. Ekstraordinær sesjon eller temasesjon holdes når presidiet beslutter det, eller når minst to regjeringer eller minst femogtyve valgte medlemmer henstiller om det.

Rådets forføyninger utøves av plenarforsamlingen, hvis ikke noe annet er særlig foreskrevet.
Plenarforsamlingens forhandlinger er offentlige, med mindre plenarforsamlingen bestemmer noe annet.

Artikkel $\mathbf{5 2}(5,6,7,9)$

Plenarforsamlingen utpeker for et kalenderår ved årlig ordinær sesjon et presidium bestående av en president og det antall andre medlemmer som angis i forretningsorden for Nordisk Råd.

Ulike politiske meningsretninger skal være representert i presidiet. Hvert land skal være representert i presidiet.

Medlemmer av presidiet skal være valgte medlemmer av Rådet.

Presidiet ivaretar Rådets løpende forretninger og opptrer for øvrig på Rådets vegne i den utstrekning som fremgår av denne overenskomst og Rådets forretningsorden.

Presidentskapet i Rådet roterer mellom de nordiske land på den måte som fremgår av forretningsorden for Nordisk Råd.

\section{Artikkel $\mathbf{5 3}(5,9)$}

Plenarforsamlingen bestemmer utvalgenes antall og forretningsområde. Utvalgenes oppgave er å forberede behandlingen av sakene i Rådet.

Artikkel $54(5,6,7,9)$

Rådet bistås i sin virksomhet av et presidiesekretariat.

\section{Artikkel $\mathbf{5 5}(5,2,7,9)$}

Regjeringene, Færøyenes landsstyre, Grønlands landsstyre, Ålands landskapsstyrelse, Ministerrådet, Rådets presidium og utvalg samt medlemmene har rett til å fremsette forslag for Rådet.

\section{Artikkel $56(5,7)$}

Rekommandasjoner vedtas av plenarforsamlingen på grunnlag av at det er fremsatt forslag om det.

Presidiet kan foreta annen fremstilling 
på grunnlag av at det er fremsatt forslag om det.

Uttalelser avgis av plenarforsamlingen. Når presidiet foretar en henvendelse (fremstilling), avgis uttalelsen av presidiet.

Presidiet skal anmelde til plenarforsamlingen de beslutninger som er truffet i henhold til andre eller tredje avsnitt.

\section{Artikkel $\mathbf{5 7}(5,7)$}

Et valgt medlem kan stille spørsmål til en regjering eller til Ministerrådet i anledning av en beretning eller meddelelse som er avgitt til Rådet, eller for øvrig om emner som angår det nordiske samarbeidet.

\section{Artikkel $58(5,2,7)$}

Hver delegasjon svarer for utgiftene til sin deltagelse i Rådet.

Presidiet beslutter for hvert budsjettår hvorledes fellesutgiftene skal fordeles mellom delegasjonene.

\section{Artikkel 59 (5)}

Plenarforsamlingen fastsetter rådets arbeidsordning. Beslutning om vedtagelse av arbeidsordningen eller om endringer i denne krever to tredjedels flertall blant rådets valgte medlemmer.

\section{Nordisk ministerråd (5)}

\section{Artikkel $60(5,2)$}

I Nordisk Ministerråd samarbeider de nordiske lands regjeringer.

Færøyenes og Grønlands landsstyrer samt Ålands landskapsstyrelse deltar i ministerrådets arbeid.

Ministerrådet treffer beslutninger i den utstrekning som angis i denne og andre avtaler mellom de nordiske land. Også i andre samarbeidsspørsmål forestår ministerrådet samarbeidet mellom de nordiske lands regjeringer og mellom regjeringene og Nordisk Råd.
Artikkel $61(5,1,2,8)$

Medlemmer av regjering, landsstyre eller landskapsstyrelsen kan i unntakstilfelle være representert på møter av befullmektiget, dog må minst tre av landene være representert av regjeringsmedlemmer.

Statsministrene har ansvaret for den overordnede samordning av nordiske samarbeidsspørsmål. De bistås av et utpekt regjeringsmedlem i hvert land (samarbeidsminister) og en statssekretær eller embetsmann (medlem av den nordiske samarbeidskomiteen).

Formannskapet roterer mellom de nordiske lands regjeringer $\mathrm{i}$ henhold til en nærmere avtale. Formannskapet har ansvaret for å samordne det nordiske regjeringssamarbeidet og for å ta de nødvendige initiativ. Formannskapet leder arbeidet i Ministerrådet, i andre ministermøter og ved regjeringenes rådslagninger om europeiske og andre internasjonale spørsmål på alle nivåer.

Ministerrådet bistås i sin virksomhet av embetsmannskomiteer og av Ministerrådets sekretariat.

\section{Artikkel 62 (5)}

Ministerrådet er beslutningsdyktig når alle landene er representert i ministerrådet. I spørsmål som utelukkende angår visse land, behøver dog bare disse land å være representert.

Hvert land har én stemme i ministerrådet.

Ministerrådets beslutninger skal være enstemmige. I prosedyrespørsmål treffes beslutning dog med enkelt flertall av dem som avgir stemme, og ved stemmelikhet gjør formannens stemme utslaget.

Stemmeunnlatelse er ikke til hinder for at beslutning fattes.

\section{Artikkel $63(5,2,8)$}

Ministerrådets beslutninger er bindende for de enkelte land. Beslutning vedrørende spørsmål som etter et av landenes forfatning krever 
godkjennelse av den folkevalgte forsamling, er dog ikke bindende for dette land før den folkevalgte forsamling har godkjent beslutningen. Hvis slik godkjennelse kreves, skal Ministerrådet underrettes om dette før Ministerrådet treffer beslutningen. Før den folkevalgte forsamlings godkjennelse foreligger, er heller ikke noe annet land bundet av beslutningen.

Beslutning truffet i overensstemmelse med denne overenskomst er bindende for Færøyene, Grønland og Åland i den utstrekning de slutter seg til beslutningen i samsvar med selvstyreordningene.

Artikkel $64(5,6,8)$

Ministerrådet skal årlig fremlegge for Nordisk Råd en beretning vedrørende det nordiske samarbeidet og en redegjørelse for planene for det fortsatte samarbeidet.

Formannskapslandets statsminister redegjør for Nordisk Råd om hovedtrekkene i samarbeidet og om regjeringenes samarbeide når det gjelder europeiske og andre internasjonale spørsmål.

Nordisk Ministerråd skal fremlegge sitt forslag til budsjett for Nordisk Råd til uttalelse.

Nordisk Råd kan foreslå endrede prioriteringer innenfor den finansielle ramme som Ministerrådet har angitt.

Med mindre det kan anføres vesentlige grunner, skal Ministerrådet følge Rådets anbefalinger når det gjelder budsjettdisposisjoner innenfor den angitte finansielle rammen.

\section{Artikkel 65 (5)}

Ministerrådet skal før hver ordinær sesjon av Nordisk Råds plenarforsamling gi rådet melding om de tiltak som er truffet i anledning av rådets rekommandasjoner og andre henvendelser. Hvis rekommandasjon eller annen henvendelse er rettet til en eller flere regjeringer, kan slik melding i stedet gis av den eller de regjeringer som rekommandasjonen eller henvendelsen er rettet til.
Artikkel 66 (5)

Ministerrådet fastsetter sin arbeidsordning.

Artikkel 67 (5)

Samråd mellom de nordiske lands regjeringer kan, foruten i ministerrådet, finne sted ved nordiske ministermøter.

\section{Endring av avtalen (5)}

Artikkel 68 (5)

Innen de kontraherende parter enes om endring i denne avtale, skal Nordisk Råd gis anledning til å uttale seg.

\section{Sluttbestemmelser}

\section{Sluttbestemmelser til overenskomsten}

23. mars 1962

\section{Artikkel 69}

Denne avtale skal ratifiseres, og ratifikasjonsdokumentene skal snarest mulig deponeres i det finske utenriksministerium.

Avtalen trer i kraft første dag i den måned som begynner nærmest etter den dag da samtlige parters ratifikasjonsdokumenter er deponert.

\section{Artikkel 70}

Ønsker noen av avtalepartene å oppsi avtalen skal skriftlig meddelelse om dette tilstilles den finske regjering som straks skal underrette de øvrige avtalepartene herom og om hvilken dag meddelelsen ble mottatt.

Oppsigelsen gjelder bare for det land som har foretatt den, og blir gyldig fra og med første dag i den måned som begynner seks måneder etter det tidspunkt den finske regjering mottok meddelelse om oppsigelsen.

Overenskomsten skal deponeres i det finske utenriksministerium, og bekreftede avskrifter skal av det finske utenriksministerium tilstilles hver enkelt avtalepart.

Til bekreftelse av dette har undertegnede befullmektigede representanter undertegnet denne avtale. 
Utferdiget i Helsingfors i ett eksemplar på dansk, finsk, islandsk, norsk og svensk, som alle har lik gyldighet, den tjuetredje mars nittenhundreogsekstito.

\section{$[\ldots]$}

\section{Sluttbestemmelser til overenskomsten}

\section{3. februar 1971}

Denne avtale skal ratifiseres og ratifikasjonsdokumentene snarest mulig deponeres $\mathrm{i}$ Finlands utenriksministerium.

Avtalen skal deponeres i utenriksministeriet i Finland og bekreftede avskrifter skal av det finske ministeriet sendes alle de kontraherende parter.

Avtalen trer i kraft tretti dager etter den dag da samtlige kontraherende staters ratifikasjonsdokument er deponert.

Til bekreftelse herav har undertegnede befullmektigede i København den 13. februar 1971 undertegnet denne avtale i ett eksemplar på dansk, finsk, islandsk, norsk og svensk, hvilke tekster alle har samme gyldighet. [...]

\section{Sluttbestemmelser til overenskomsten}

\section{1. mars 1974}

Denne avtale skal ratifiseres og ratifikasjonsdokumentene skal snarest mulig deponeres i det finske utenriksministerium.

Avtalen skal deponeres i det finske utenriksministerium, og bekreftede avskrifter skal av det finske ministerium tilstilles hver enkelt avtalepart.

Avtalen trer i kraft tretti dager etter den dag da samtlige avtaleparters ratifikasjonsdokumenter er deponert.

Til bekreftelse herav har undertegnede befullmektigede representanter i København den 11. mars 1974 undertegnet denne avtale i ett eksemplar på dansk, finsk, islandsk, norsk og svensk, hvilke tekster alle har samme gyldighet.

\section{[...]}

Sluttbestemmelser til overenskomsten 15. juni 1983

Denne avtale skal ratifiseres og ratifikasjonsdokumentene snarest mulig deponeres $\mathrm{i}$ det finske utenriksministerium som skal overlevere bekreftede kopier av avtalen til de øvrige kontraherende parter.

Avtalen trer i kraft tretti dager etter den dag da samtlige kontraherende parters ratifikasjonsdokumenter er deponert.

Til bekreftelse herav har de undertegnede representanter som er blitt behørig bemyndiget, i Reykjavik den 15. juni 1983, undertegnet denne avtale i ett eksemplar på dansk, finsk, islandsk, norsk og svensk, hvilke tekster alle har samme gyldighet.

[...]

\section{Sluttbestemmelser til overenskomsten}

6. mai 1985

Overenskomsten trer i kraft tretti dager etter den dag da samtlige avtaleparter har meddelt Finlands utenriksministerium at de tiltak som kreves for overenskomstens ikrafttredelse, er iverksatt.

Finlands utenriksministerium underretter de øvrige avtaleparter om tidspunktet for mottakelsen av disse meddelelser.

Originaleksemplaret til denne overenskomst deponeres hos Finlands utenriksministerium, som tilstiller de øvrige avtaleparter bekreftede kopier av overenskomsten.

Til bekreftelse av dette, har undertegnede representanter som er blitt behørig bemyndiget, undertegnet denne overenskomst.

Som fant sted i Lund den 6. mai 1985 i ett eksemplar på dansk, finsk, islandsk, norsk og svensk, hvilke tekster alle har samme gyldighet.

[...] 
Sluttbestemmelser til overenskomsten

21. august 1991

Overenskomsten trer i kraft tredve dager etter den dag samtlige parter har gitt det finske utenriksdepartementet meddelelse om sin godkjennelse av overenskomsten.

Det finske utenriksdepartement underretter de øvrige parter om mottagelsen av disse meddelelser og om tidspunktet for overenskomstens ikrafttreden.

Originaleksemplaret til denne overenskomsten deponeres i det finske utenriksdepartementet, som tilstiller de øvrige parter bekreftede gjenparter av det.

Til bekreftelse herav har de undertegnede befullmektigede representanter, undertegnet denne overenskomst.

Utferdiget i Tammerfors den 21. august 1991 i ett eksemplar på dansk, finsk, islandsk, norsk og svensk, som alle har samme gyldighet.

[...]

\section{Sluttbestemmelser til overenskomsten}

18. mars 1993

Overenskomsten trer i kraft tredve dager etter den dag da samtlige avtaleparter har meddelt Finlands utenriksministerium at overenskomsten er godkjent.

Finlands utenriksministerium underretter de øvrige avtaleparter om mottagelsen av disse meddelelser og om tidspunktet for overenskomstens ikrafttreden.

Originaleksemplaret til denne overenskomst deponeres hos Finlands utenriksministerium, som tilstiller de øvrige avtaleparter bekreftede gjenparter.

Til bekreftelse av dette har de behørig befullmektigede representanter undertegnet denne overenskomst.

Som fant sted i Helsingfors den 18. mars 1993 i ett eksemplar på dansk, finsk, islandsk, norsk og svensk, som alle har samme gyldighet.

[...]

\section{Sluttbestemmelser til overenskomsten}

\section{9. september 1995}

Overenskomsten trer i kraft femten dager etter den dag da samtlige avtaleparter har meddelt Finlands utenriksministerium at overenskomsten er godkjent.

Finlands utenriksministerium underretter de øvrige avtaleparter om mottakelsen av disse meddelelser, og om tidspunktet for overenskomstens ikrafttredelse.

Originaleksemplaret til denne overenskomst deponeres hos Finlands utenriksministerium, som tilstiller de øvrige avtaleparter bekreftede gjenparter.

Til bekreftelse av dette har de behørig befullmektigede representanter undertegnet denne overenskomst.

Som fant sted i København den 29. september 1995 i ett eksemplar på dansk, finsk, islandsk, norsk og svensk, som alle har samme gyldighet.

[...] 


\section{Fotnoter}

1 Opprinnelig ordlyd ble endret i 1974.

2 Opprinnelig ordlyd ble endret i 1983.

3 Artiklene tilkom 1974.

4 Opprinnelig ordlyd ble endret i 1971.

5 Artiklene tilkom 1971.

6 Ny ordlyd 1985.

7 Ny ordlyd 1991.

8 Ny ordlyd 1993.

9 Ny ordlyd 1995. 


\section{Helsingforsaftalen}

\author{
Samarbejdsoverenskomst mellem \\ Danmark, Finland, Island, Norge og \\ Sverige (Helsingforsaftalen). \\ Overenskomsten undertegnedes den
}

23. marts 1962 og trådte i kraft den 1 . juli

samme år. Den oprindelige tekst er ændret ved overenskomster, som undertegnedes

den 13. februar 1971, den 11. marts 1974, den 15. juni 1983, den 6. maj 1985, den

21. august 1991, den 18. marts 1993

og den 29. september 1995. De seneste

ændringer trådte i kraft den 2. januar 1996.

\section{Præambel til overenskomsten af}

\section{3. marts 1962}

Danmarks, Finlands, Islands, Norges og

Sveriges regeringer

som yderligere vil fremme det nære

fællesskab, der i kultur samt i rets- og sam-

fundsopfattelse består mellem de nordiske

folk og yderligere vil udvikle samarbejdet

mellem de nordiske lande;

som tilstræber at gennemføre ensartede retsregler i de nordiske lande i så mange henseender som muligt;

som på alle de områder, hvor forudsætningerne derfor er til stede, vil tilvejebringe en hensigtsmæssig arbejdsdeling mellem landene;

som vil fortsætte det for landene betydningsfulde samarbejde inden for Nordisk Råd og inden for de øvrige samarbejdsorganer;

er blevet enige om følgende bestemmelser:

\section{Præambel til overenskomsten af}

\section{3. februar 1971}

Danmarks, Finlands, Islands, Norges og

Sveriges regeringer,

som vil styrke og yderligere udbygge det institutionelle grundlag for samarbejdet mellem de nordiske lande,

som med henblik herpå finder det formålstjenligt at ændre samarbejdsoverenskomsten af 23. marts 1962 mellem de nordiske lande,

som derfor har besluttet at indføre de grundlæggende bestemmelser om Nordisk Råd i samarbejdsoverenskomsten,

som tillige har besluttet i samarbejdsoverenskomsten at indføre bestemmelser om et Nordisk Ministerråd med beføjelser for hele det nordiske samarbejdsområde,

er blevet enige om følgende:

\section{Præambel til overenskomsten af}

\section{1. marts 1974}

Danmarks, Finlands, Islands, Norges og

Sveriges regeringer,

som ved overenskomst af 13. februar 1971 har ændret samarbejdsoverenskomsten af 23. marts 1962 mellem de nordiske lande, som finder det formålstjenligt at foretage visse yderligere ændringer i og tilføjelser til overenskomsten,

er blevet enige om følgende:

\section{Præambel til overenskomsten af}

\section{5. juni 1983}

Danmarks, Finlands, Islands, Norges og

Sveriges regeringer,

som ved overenskomster af 13. februar 1971 og 11. marts 1974 har ændret samarbejdsoverenskomsten af 23. marts 1962 mellem de nordiske lande, som finder det formålstjenligt at foretage visse ændringer i overenskomsten for at give Færøerne og Åland øget repræsentation i Nordisk Råd og Nordisk Ministerråd og for at give Grønland samme repræsentation i disse organer,

er blevet enige om følgende: 
Præambel til overenskomsten af

6. maj 1985

Danmarks, Finlands, Islands, Norges og

Sveriges regeringer, som ved overenskomster af 13. februar

1971, 11. marts 1974 og 15. juni 1983 har

ændret samarbejdsoverenskomsten af

23. marts 1962 mellem de nordiske lande,

og

som ønsker at effektivisere det nordiske

samarbejdes arbejdsformer, er blevet enige om følgende:

\section{Præambel til overenskomsten af}

\section{1. august 1991}

Danmarks, Finlands, Islands, Norges og

Sveriges regeringer, som ved overenskomster af den 13.

februar 1971, den 11. marts 1974, den 15 . juni 1983 og den 6. maj 1985 har ændret samarbejdsoverenskomsten af 23. marts 1962 mellem de nordiske lande, og som finder det formålstjenligt med visse ændringer af Nordisk Råds organisation og arbejdsformer, er blevet enige om følgende:

\section{Præambel til overenskomsten af}

\section{8. marts 1993}

Danmarks, Finlands, Islands, Norges og

Sveriges regeringer,

som ved overenskomster af den 13. februar 1971, den 11. marts 1974, den 15. juni 1983, den 6. maj 1985 og den 21. august 1991 har ændret samarbejdsoverenskomsten af den 23. marts 1962 mellem de nordiske lande, og som ønsker at forny og udvikle det nordiske samarbejde i lyset af de nordiske landes udvidede deltagelse i det europæiske samarbejde;

er blevet enige om følgende:

\section{Præambel til overenskomsten af}

\section{9. september 1995}

Danmarks, Finlands, Islands, Norges og

Sveriges regeringer,

som ved overenskomster af 13. februar

1971,11 . marts 1974,15 . juni 1983, 6. maj

1985, 21. august 1991 og 18. marts 1993

har ændret samarbejdsoverenskomsten af 23. marts 1962 mellem de nordiske lande,

og

som ønsker at forny og udvikle det nordiske samarbejde i lyset af de nordiske landes udvidede deltagelse i det europæiske sam-

arbejde,

er blevet enige om følgende:

\section{Indledende bestemmelse}

Artikel $1(1,8)$

De kontraherende parter skal bestræbe sig på at bevare og yderligere udvikle samarbejdet mellem landene på det retslige, det kulturelle, det sociale og det økonomiske område såvel som i spørgsmål vedrørende samfærdselen og miljøbeskyttelsen.

De kontraherende parter bør rådføre sig med hinanden i spørgsmål af fælles interesse, som behandles i europæiske og andre internationale organisationer og konferencer.

\section{Retsligt samarbejde}

\section{Artikel 2 (9)}

Ved udformningen af love og andre retsregler i de nordiske lande skal statsborgere i de øvrige nordiske lande sidesstilles med landets egne statsborgere. Dette gælder inden for samarbejdsoverenskomstens virkeområde.

Undtagelse fra første stykke kan dog gøres, hvis krav om statsborgerskab er grundlovsfæstet, nødvendigt på grund af andre internationale forpligtelser eller det i øvrigt af særlige grunde skønnes nødvendigt. 


\section{Artikel 3}

De kontraherende parter skal søge at lette adgangen for statsborgere $i$ et nordisk land til at opnå statsborgerskab i et andet nordisk land.

\section{Artikel 4}

De kontraherende parter skal fortsætte lovgivningssamarbejdet med henblik på at opnå den størst mulige overensstemmelse på privatrettens område.

\section{Artikel 5}

De kontraherende parter bør tilstræbe ensartede bestemmelser om forbrydelser og strafferetlige retsfølger.

Med hensyn til forbrydelser, der er begået $i$ et nordisk land, bør efterforskning og strafforfølgning i videst mulig udstrækning kunne finde sted også i et andet nordisk land.

\section{Artikel 6}

De kontraherende parter skal tilstræbe indbyrdes samordning af anden lovgivning end den her nævnte på områder, hvor dette findes hensigtsmæssigt.

\section{Artikel 7}

Enhver af de kontraherende parter bør virke for at gennemføre sådanne bestemmelser, at afgørelser truffet af domstole eller andre myndigheder $\mathrm{i}$ et andet nordisk land tillige kan fuldbyrdes inden for partens område.

\section{Kulturelt samarbejde}

\section{Artikel 8 (2)}

I alle de nordiske lande skal undervisningen og uddannelsen i skolerne i passende omfang omfatte undervisning i de øvrige nordiske landes, herunder Færøernes, Grønlands og Ålands, sprog, kultur og almindelige samfundsforhold.

\section{Artikel 9}

Enhver af de kontraherende parter bør opretholde og øge mulighederne for at studerende, hjemmehørende i et andet nordisk land, kan drive studier og aflægge eksaminer ved sine uddannelsesinstitutioner. En deleksamen bestået i et nordisk land bør i størst mulig udstrækning anerkendes og medregnes ved afsluttende eksaminer $\mathrm{i}$ et andet nordisk land.

$\varnothing$ konomisk støtte fra hjemlandet bør kunne ydes, uanset til hvilket land studierne henlægges.

\section{Artikel 10}

De kontraherende parter bør samordne den af det offentlige anordnede uddannelse, der tager sigte på at give beføjelse til at udøve bestemte erhverv.

Sådan uddannelse bør så vidt muligt give samme beføjelse til erhvervsudøvelse i alle de nordiske lande. Der kan dog stilles krav om sådan tillægsuddannelse, som nødvendiggøres af hensyn til nationale forhold.

\section{Artikel 11}

På de områder, hvor et samarbejde er hensigtsmæssigt, bør udbygningen af uddannelsesinstitutionerne samordnes gennem stadigt samvirke om udbygningsplanerne og disses gennemførelse.

\section{Artikel 12}

Samarbejde på forskningens område bør være således tilrettelagt, at disponible forskningsbevillinger og andre midler samordnes og udnyttes på den bedst mulige måde, blandt andet ved oprettelse af fælles institutioner.

\section{Artikel 13}

Med det formål at støtte og styrke den kulturelle udvikling skal de kontraherende parter fremme det frie nordiske folkeoplysningsarbejde og udvekslingen inden for litteratur, kunst, musik, teater, film og de øvrige kulturområder, hvorved blandt andet de muligheder, som radio og fjernsyn frembyder, bør udnyttes. 


\section{Socialt samarbejde}

\section{Artikel 14}

De kontraherende parter skal bestræbe sig på at bevare og videreudvikle det fælles nordiske arbejdsmarked efter de retningslinjer, der er blevet afstukket i tidligere aftaler. Arbejdsanvisning og erhvervsvejledning skal samordnes. Udvekslingen af praktikanter skal være fri.

Ensartethed i udformningen af de nationale regler vedrørende arbejderbeskyttelse og lignende spørgsmål bør tilstræbes.

\section{Artikel 15}

De kontraherende parter skal virke for, at statsborgere i et nordisk land ved ophold i et andet nordisk land i størst mulig udstrækning skal kunne oppebære sådanne sociale ydelser, som ydes i opholdslandet til dettes egne statsborgere.

\section{Artikel 16}

De kontraherende parter skal videreudvikle samarbejdet med hensyn til sundheds- og sygevæsen, alkoholikerforsorg samt børneog ungdomsforsorg.

\section{Artikel 17}

Enhver af de kontraherende parter skal virke for, at medicinsk, teknisk eller anden lignende sikkerhedskontrol udføres på en sådan måde, at attester vedrørende kontrollen kan anerkendes i de øvrige nordiske lande.

\section{Økonomisk samarbejde}

\section{Artikel 18}

De kontraherende parter skal med henblik på at fremme det nordiske økonomiske samarbejde på forskellige områder rådføre sig med hinanden i spørgsmål vedrørende den økonomiske politik. I denne forbindelse bør opmærksomheden rettes mod mulighederne for at samordne foranstaltninger, som iværksættes i konjunkturudjævnende øjemed.

\section{Artikel 19}

De kontraherende parter tilsigter så vidt muligt at fremme produktions- og investeringssamarbejde mellem deres lande og herunder søge at lægge forholdene til rette med henblik på direkte samarbejde mellem virksomheder i to eller flere af de nordiske lande. De kontraherende parter bør som et led $i$ et videre internationalt samarbejde stræbe efter at opnå en hensigtsmæssig arbejdsdeling imellem landene forsåvidt angår produktion og investeringer.

\section{Artikel 20}

De kontraherende parter skal virke for den størst mulige frihed for kapitalbevægelser mellem de nordiske lande. Fælles løsninger af andre betalings- og valutaspørgsmål af fælles interesse skal tilstræbes.

\section{Artikel 21}

De kontraherende parter skal bestræbe sig på at befæste det samarbejde, der tidligere er blevet indledt med henblik på at fjerne handelsskrankerne imellem de nordiske lande, samt såvidt muligt yderligere at styrke og udvikle dette samarbejde.

\section{Artikel 22}

De kontraherende parter skal i internationale handelspolitiske spørgsmål såvel hver for sig som i fællesskab søge at fremme nordiske interesser og med henblik herpå rådføre sig med hverandre.

\section{Artikel 23}

De kontraherende parter skal virke for samordning af de toldtekniske og toldadministrative bestemmelser samt for sådanne forenklinger i toldanliggender, som er egnede til at lette samfærdselen mellem landene.

\section{Artikel 24}

Bestemmelserne vedrørende den nordiske grænsehandel skal udformes således, at 
grænseområdernes indbyggere påføres

mindst mulig ulempe.

\section{Artikel 25}

Når der foreligger behov og forudsætninger for fælles økonomisk udbygning af sådanne territorier inden for to eller flere kontraherende parters områder, som grænser op til hverandre, skal disse parter sammen søge at fremme en sådan udbygning.

\section{Samarbejde på samfærdselens område}

\section{Artikel 26}

De kontraherende parter skal bestræbe sig på at befæste det samarbejde, der tidligere er indledt på samfærdselens område, samt søge at udvikle dette samarbejde med henblik på at lette forbindelserne og vareudvekslingen mellem landene og opnå en hensigtsmæssig løsning af de problemer, som måtte forekomme på dette område.

\section{Artikel 27}

Bygning af samfærdselsforbindelser, der berører to eller flere kontraherende parters områder, skal ske i samråd mellem de berørte parter.

\section{Artikel 28}

De kontraherende parter skal søge at bevare og videreudvikle det samarbejde, der har ført til, at deres territorier udgør ét paskontrolområde. Kontrollen med rejsende, som passerer grænser mellem nordiske lande, skal også i øvrigt forenkles og samordnes.

\section{Artikel 29}

De kontraherende parter skal samordne arbejdet for øget trafiksikkerhed.
Samarbejde på miljøbeskyttelsesområdet (3)

\section{Artikel 30 (3)}

De kontraherende parter skal ved udformningen og gennemførelsen af national lovgivning i størst muligt omfang ligestille de øvrige kontraherende parters miljøbeskyttelsesinteresser med deres egne.

\section{Artikel 31 (3)}

De kontraherende parter skal tilstræbe harmonisering af deres miljøbeskyttelsesregler med henblik på at opnå den størst mulige overensstemmelse for så vidt angår normer og retningslinjer for udtømning af forurening, anvendelse af miljøgifte samt andre miljøforstyrrelser.

\section{Artikel 32 (3)}

De kontraherende parter skal tilstræbe samordning for så vidt angår udvælgelse af naturværns- og friluftsområder samt fredning og andre foranstaltninger til beskyttelse af vækster og dyr.

\section{Samarbejdet i øvrigt}

\section{Artikel 33 (8)}

De kontraherende parters deltagelse i europæisk og andet internationalt samarbejde giver gode muligheder for samarbejde til fordel for nordiske statsborgere og virksomheder. Der påhviler i denne sammenhæng regeringerne et særligt ansvar for at varetage fælles interesser og vurderinger.

\section{Artikel 34}

Embedsmænd, som tilhører en kontraherende parts udenrigstjeneste, og som forretter tjeneste uden for de nordiske lande, skal, i det omfang det er foreneligt med hans tjenstlige pligter, og det ikke møder hindringer fra det lands side, hvori vedkommende forretter tjeneste, tillige bistå statsborgere fra et andet 
nordisk land, såfremt dette ikke har nogen repræsentation på det pågældende sted.

\section{Artikel 35}

De kontraherende parter bør, når som helst det findes muligt og hensigtsmæssigt, samordne deres virksomhed vedrørende bistand til og samarbejde med udviklingslandene.

\section{Artikel 36}

Foranstaltninger, der tager sigte på at udbrede øget kendskab til de nordiske lande og det nordiske samarbejde, bør iværksættes i nært samarbejde mellem de kontraherende parter og deres organer for oplysning i udlandet. Hvor det skønnes hensigtsmæssigt, kan det gøres ved fælles optræden.

\section{Artikel 37}

De kontraherende parter skal virke for, at forskellige områder inden for den offentlige statistik samordnes.

\section{Særlige overenskomster (3)}

\section{Artikel 38 (3)}

Nærmere bestemmelser om samarbejdet inden for de nu angivne områder kan fastsættes i særlige overenskomster.

\section{Formerne for nordisk samarbejde}

\section{Artikel 39 (4)}

For at gennemføre og videreudvikle det nordiske samarbejde i henhold til denne og andre overenskomster bør de nordiske lande til stadighed rådføre sig med hinanden og hvor behov foreligger træffe samordnende foranstaltninger.

Artikel $40(4,8)$

Samarbejdet finder sted i Nordisk Råd, i Nordisk Ministerråd, på statsministrenes, på udenrigsministrenes samt på andre ministres møder, i særlige samarbejdsorganer og mellem landenes fagmyndigheder.

\section{Artikel 41}

Bestemmelser, som er blevet til efter samarbejde mellem to eller flere kontraherende parter, må ikke ændres af en part, med mindre de øvrige parter underrettes derom. Sådan underretning kræves dog ikke i hastende tilfælde, eller hvor det drejer sig om bestemmelser af mindre betydning.

\section{Artikel 42}

Myndighederne i de nordiske lande skal kunne korrespondere direkte med hverandre i andre anliggender end sådanne, som ifølge deres natur eller af anden grund bør behandles ved udenrigstjenestens foranstaltning.

\section{Artikel 43 (3)}

I det nordiske samarbejde bør der iagttages størst mulig offentlighed.

\section{Nordisk Råd (5)}

\section{Artikel $44(5,2)$}

I Nordisk Råd samarbejder de nordiske landes samt Færøernes, Grønlands og Ålands folkevalgte forsamlinger, landenes regeringer, Færøernes landsstyre, Grønlands landsstyre samt Ålands landskapsstyrelse. Rådet er initiativtagende og rådgivende i spørgsmål, som angår samvirket mellem disse lande eller nogle af dem og Færøerne, Grønland og Åland, samt har i øvrigt de opgaver, der fremgår af denne og andre overenskomster.

\section{Artikel 45 (5)}

Rådet kan vedtage rekommandationer og rette andre henvendelser eller afgive udtalelser til en eller flere af de nordiske landes regeringer eller til Ministerrådet.

\section{Artikel 46 (5)}

Ud over hvad der særligt er aftalt, bør Rådet gives lejlighed til at udtale sig om nordiske samarbejdsspørgsmål af større betydning, når dette ikke er umuligt af tidshensyn. 
Artikel $47(5,2,8)$

Rådet består af 87 valgte medlemmer, regeringsrepræsentanter og repræsentanter for Færøernes landsstyre, Grønlands landsstyre samt Ålands landskapsstyrelse.

Af medlemmerne vælger Danmarks folketing seksten, Finlands riksdag atten, Islands alting syv, Norges storting og Sveriges riksdag hver tyve, samt Færøernes lagting, Grønlands landsting og Ålands lagting hver to. Desuden vælger hver forsamling et tilsvarende antal suppleanter.

Valg af medlemmer og suppleanter foretages årligt og gælder for tiden indtil næste valg. Ved valg skal forskellige politiske meningsretninger gives repræsentation $\mathrm{i}$ rådet.

Kun medlemmer af den forsamling, der har foretaget valget, kan være valgt medlem eller suppleant i rådet.

Regeringerne, landsstyrerne og landskapsstyrelsen udpeger blandt deres medlemmer det antal repræsentanter, de ønsker.

\section{Artikel $\mathbf{4 8}(5,2,8,9)$}

Danmarks Riges delegation består af de af Folketinget valgte medlemmer og de af regeringen udpegede repræsentanter samt Færøernes og Grønlands i andet stykke nævnte delegationer. Finlands delegation består af de af Riksdagen valgte medlemmer og de af regeringen udpegede repræsentanter samt af Ålands i andet stykke nævnte delegation. For hvert af de øvrige lande består delegationen af den folkevalgte forsamling valgte medlemmer og de af regeringen udpegede repræsentanter.

Færøernes delegation består af de af Lagtinget valgte medlemmer og de af landsstyret udpegede repræsentanter. Grønlands delegation består af de af Landstinget valgte medlemmer og de af landsstyret udpegede repræsentanter. Ålands delegation består af de af Lagtinget valgte medlemmer og de af landskapsstyrelsen udpegede repræsentanter.
Ved "delegation" forstås i artikel 58, andet stykke, landets delegation.

\section{Artikel $49(5,2)$}

Regeringsrepræsentanterne samt landsstyrernes og landskapsstyrelsens repræsentanter har ikke stemmeret i Rådet.

I spørgsmål, som angår anvendelsen af overenskomster mellem visse lande, har kun medlemmer fra disse lande stemmeret.

\section{Artikel 50 (5)}

Rådets organer er Plenarforsamlingen, Præsidiet og Udvalgene.

Artikel $\mathbf{5 1}(5,7,9)$

Plenarforsamlingen består af alle medlemmer af Rådet.

Plenarforsamlingen holder ordinær session mindst én gang om året. Ekstraordinære sessioner eller temasessioner holdes, når Præsidiet træffer beslutning herom, eller når mindst to regeringer eller mindst femogtyve valgte medlemmer begærer det.

Rådets beføjelser udøves af plenarforsamlingen, såfremt ikke andet er særligt foreskrevet.

Plenarforsamlingens forhandlinger er offentlige, såfremt plenarforsamlingen ikke beslutter andet.

\section{Artikel $\mathbf{5 2}(5,6,7,9)$}

Plenarforsamlingen udpeger for et kalenderår ved den ordinære session et præsidium bestående af en præsident og det antal medlemmer, som er anført i Nordisk Råds forretningsorden.

Forskellige politiske meningsretninger skal være repræsenteret i Præsidiet. Hvert land skal være repræsenteret i Præsidiet.

Medlemmerne af Præsidiet skal være valgte medlemmer af Rådet.

Præsidiet varetager Rådets løbende forretninger og repræsenterer i øvrigt Rådet i den udstrækning, som fremgår af denne overenskomst og Rådets forretningsorden. 
Rådets formandskab varetages på skift af de nordiske lande i overensstemmelse med Nordisk Råds forretningsorden.

Artikel $\mathbf{5 3}(5,9)$

Plenarforsamlingen bestemmer udvalgenes antal og virksomhedsområder. Udvalgene har til opgave at forberede sagernes behandling i rådet.

Artikel 54 (5,6,7,9)

Rådet bistås i sin virksomhed af et præsidiesekretariat.

\section{Artikel 55 (5,2,7,9)}

Regeringerne, Færøernes landsstyre, Grønlands landsstyre, Ålands landskapsstyrelse, Ministerrådet, Rådets Præsidium og udvalgene samt ethvert medlem har ret til at stille forslag i Rådet.

\section{Artikel $56(5,7)$}

Rekommandationer vedtages af plenarforsamlingen på grundlag af fremsat forslag herom.

Anden henvendelse (fremstilling) kan foretages af præsidiet på grundlag af fremsat forslag herom.

Udtalelser afgives af plenarforsamlingen. Når præsidiet foretager henvendelse (fremstilling), afgives udtalelse af præsidiet.

Præsidiet skal til plenarforsamlingen anmelde de foranstaltninger, der er truffet i henhold til andet eller tredje afsnit.

\section{Artikel $\mathbf{5 7}(5,7)$}

Et valgt medlem kan stille spørgsmål til regering eller til ministerrådet i anledning af beretning eller meddelelse, der er afgivet til rådet, eller i øvrigt om emner, som angår det nordiske samarbejde.

Artikel 58 (5,2,7)

Hver delegation svarer for udgifterne til sin deltagelse i rådet.
Præsidiet træffer for hvert budgetår bestemmelse om, hvorledes de fælles udgifter skal fordeles mellem delegationerne.

Artikel 59 (5)

Plenarforsamlingen fastsætter Rådets arbejdsordning. Beslutning om vedtagelse af arbejdsordningen eller om ændringer i denne kræver to trediedeles flertal blandt Rådets valgte medlemmer.

\section{Nordisk Ministerråd (5)}

Artikel $60(5,2)$

I Nordisk Ministerråd samarbejder de nordiske landes regeringer.

Færøernes landsstyre, Grønlands landsstyre samt Ålands landskapsstyrelse deltager i ministerrådets arbejde.

Ministerrådet træffer beslutninger i den udstrækning, som angives i denne og andre overenskomster mellem de nordiske lande. Også i øvrige samarbejdsspørgsmål har ministerrådet ansvar for samarbejdet mellem de nordiske landes regeringer og mellem regeringerne og Nordisk Råd.

Artikel $61(5,1,2,8)$

Medlemmer af en regering, et landsstyre eller landskapsstyrelsen kan i undtagelsestilfælde på et møde være repræsenterede ved en dertil befuldmægtiget; dog skal mindst tre af landenes regeringer være repræsenterede ved regeringsmedlemmer.

Statsministrene har ansvaret for den overordnede samordning af nordiske samarbejdsspørgsmål. De bistås af et udpeget regeringsmedlem i hvert land (samarbejdsminister) og en statssekretær eller embedsmand i hvert land (medlem af den nordiske samarbejdskomite).

Formandskabet skifter mellem de nordiske landes regeringer efter nærmere aftale. Formandskabet har ansvaret for at samordne det nordiske regeringssamarbejde og for at 
tage de nødvendige initiativer. Formandskabet leder arbejdet i ministerrådet, på andre ministermøder og ved regeringernes samråd om europæiske og andre internationale spørgsmål på alle niveaver.

Ministerrådet bistås i sin virksomhed af embedmandskomiteer og af ministerrådets sekretariat.

\section{Artikel 62 (5)}

Ministerrådet er beslutningsdygtigt, når repræsentanter for alle landene er til stede i ministerrådet. I spørgsmål, som udelukkende angår visse lande, behøver dog kun disse lande at være repræsenterede.

Hvert land har én stemme i Ministerrådet.

Ministerrådets beslutninger skal være enstemmige. I procedurespørgsmål træffes beslutning dog ved simpelt flertal blandt de i afstemningen deltagende. Står stemmetallet lige, er formandens stemme afgørende.

Undladelse af at afgive stemme er ikke til hinder for at beslutninger træffes.

\section{Artikel $63(5,2,8)$}

Ministerrådets beslutninger er bindende for de enkelte lande. Beslutninger vedrørende spørgsmål, som i henhold til et lands forfatning kræver den folkevalgte forsamlings godkendelse, binder dog ikke dette land, før forsamlingen har godkendt beslutningen. Kræves sådan godkendelse, skal ministerrådet underrettes herom, inden ministerrådet træffer beslutningen. Før den folkevalgte forsamlings godkendelse foreligger, er de øvrige lande heller ikke bundet af beslutningen.

Beslutninger truffet i overensstemmelse med denne overenskomst er bindende for Færøerne, Grønland og Åland, i det omfang de tilslutter sig beslutningen i overensstemmelse med selvstyreordningerne.
Artikel 64 (5,6,8)

Ministerrådet skal årligt fremlægge en beretning for Nordisk Råd vedrørende det nordiske samarbejde og en redegørelse for planerne for det fortsatte samarbejde.

Formandslandets statsminister redegør for Nordisk Råd for hovedtrækkene i samarbejdet og om regeringernes samarbejde vedrørende europæiske og andre internationale spørgsmål.

Nordisk Ministerråd skal fremlægge sit forslag til budget for Nordisk Råd til udtalelse.

Nordisk Råd kan foreslå ændrede prioriteringer inden for den af ministerrådet angivne finansielle ramme.

Hvis ikke særlige omstændigheder kan anføres, skal ministerrådet følge rådets anbefalinger, når det gælder budgetdispositioner inden for den angivne finansielle ramme.

\section{Artikel 65 (5)}

Ministerrådet skal før hver ordinær session i Nordisk Råds Plenarforsamling give Rådet meddelelse om de foranstaltninger, der er truffet i anledning af Rådets rekommandationer og andre henvendelser. Hvis en rekommandation eller anden henvendelse er rettet til en eller flere regeringer, kan sådan meddelelse i stedet gives af den eller de regeringer, hvortil rekommandationen eller henvendelsen er rettet.

\section{Artikel 66 (5)}

Ministerrådet fastsætter sin arbejdsordning.

\section{Artikel 67 (5)}

Samråd mellem de nordiske landes regeringer kan foruden i Ministerrådet ske ved nordiske ministermøder.

\section{Endring af overenskomsten (5)}

\section{Artikel 68 (5)}

Inden landene træffer overenskomst om ændringer i denne overenskomst, skal Nordisk Råd have lejlighed til at udtale sig. 


\section{Slutbestemmelser}

Slutbestemmelser til overenskomsten af den 23. marts 1962

\section{Artikel 69}

Denne overenskomst skal ratificeres, og ratifikationsinstrumenterne skal snarest muligt deponeres i det finske udenrigsministerium.

Overenskomsten træder i kraft den første dag i den måned, der begynder nærmest efter den dag, da samtlige kontraherende parters ratifikationsinstrumenter er blevet deponeret.

\section{Artikel 70}

Ønsker nogen af de kontraherende parter at opsige overenskomsten, skal skriftlig meddelelse herom sendes til den finske regering, som umiddelbart skal underrette de øvrige kontraherende parter herom samt om datoen for meddelelsens modtagelse.

Opsigelsen gælder kun det land, der har indgivet den, og får gyldighed fra og med den første dag i den måned, der begynder seks måneder efter den dag da den finske regering modtog meddelelsen om opsigelsen.

Overenskomsten skal deponeres i det finske udenrigsministeriums arkiv, og bekræftede afskrifter skal af det finske udenrigsministerium sendes til hver af de kontraherende parter.

Til bekræftelse heraf har undertegnede befuldmægtigede repræsentanter undertegnet denne overenskomst.

Udfærdiget i Helsingfors i et eksemplar på dansk, finsk, islandsk, norsk og svensk, hvilke tekster alle skal have samme gyldighed, den treogtyvende marts nittenhundrede og toogtres.

[...]

\section{Slutbestemmelser til overenskomsten af} den 13. februar 1971

Denne overenskomst skal ratificeres, og ratifikationsinstrumenterne skal snarest muligt deponeres i Finlands udenrigsministerium.

Overenskomsten skal deponeres i Finlands udenrigsministerium, og bekræftede afskrifter skal tilstilles hver af de kontraherende parter af det finske ministerium.

Overenskomsten træder i kraft 30 dage efter den dag, hvor samtlige kontraherende parters ratifikationsinstrumenter er deponerede.

Til bekræftelse heraf har undertegnede befuldmægtigede i København den 13. februar 1971 undertegnet denne overenskomst i et eksemplar på dansk, finsk, islandsk, norsk og svensk, hvilke tekster alle har samme gyldighed.

[...]

\section{Slutbestemmelser til overenskomsten af} den 11. marts 1974

Denne overenskomst skal ratificeres, og ratifikationsinstrumenterne skal snarest muligt deponeres i Finlands udenrigsministerium.

Overenskomsten skal deponeres i Finlands udenrigsministerium, og bekræftede afskrifter skal tilsendes hver af de kontraherende parter af det finske ministerium.

Overenskomsten træder i kraft 30 dage efter den dag, da samtlige kontraherende parters ratifikationsinstrumenter er blevet deponeret.

Til bekræftelse heraf har undertegnede befuldmægtigede i København den 11. marts 1974 undertegnet denne overenskomst i et eksemplar på dansk, finsk, islandsk, norsk og svensk, hvilke tekster alle har samme gyldighed. [...]

\section{Slutbestemmelser til overenskomsten af} den 15. juni 1983

Denne overenskomst skal ratificeres, og ratifikationsdokumenterne skal snarest muligt deponeres i Finlands udenrigsministerium, der skal sende bekræftede afskrifter af overenskomsten til de øvrige kontraherende parter.

Overenskomsten træder i kraft 30 dage efter den dag, hvor samtlige kontraherende parters ratifikationsinstrumenter er deponerede. 
Til bekræftelse heraf har undertegnede befuldmægtigede i Reykjavik den 15. juni 1983 undertegnet denne overenskomst i et eksemplar på dansk, finsk, islandsk, norsk og svensk, hvilke tekster alle har samme gyldighed.

[...]

\section{Slutbestemmelser til overenskomsten af}

den 6. maj 1985

Overenskomsten træder i kraft tredive dage efter den dag, hvor samtlige kontraherende parter har meddelt det finske udenrigsministerium, at de foranstaltninger, som kræves for overenskomstens ikrafttrædelse, er gennemført.

Det finske udenrigsministerium meddeler de øvrige kontraherende parter tidspunktet for modtagelsen af disse meddelelser.

Originaleksemplaret til denne overenskomst deponeres i det finske udenrigsministerium, som vil oversende bekræftede kopier til de øvrige kontraherende parter.

Til bekræftelse heraf har undertegnede, som er behørigt bemyndiget dertil, undertegnet denne overenskomst.

Udfærdiget i Lund den 6. maj 1985 i et eksemplar på dansk, finsk, islandsk, norsk og svensk, hvilke tekster alle har samme gyldighed.

[...]

\section{Slutbestemmelser til overenskomsten af}

\section{den 21. august 1991}

Overenskomsten træder i kraft tredive dage efter den dag, hvor samtlige parter har givet det finske udenrigsministerium meddelelse om deres godkendelse af overenskomsten.

Det finske udenrigsministerium underretter de øvrige parter om modtagelsen af disse meddelelser og om tidspunktet for overenskomstens ikrafttrædelse.

Originalteksten til denne overenskomst deponeres i det finske udenrigsministerium, der tilstiller de øvrige parter bekræftede genparter heraf.
Til bekræftelse heraf har undertegnede befuldmægtigede repræsentanter undertegnet denne overenskomst.

Udfærdiget i Tammerfors den 21. august 1991 i et eksemplar på dansk, finsk, islandsk, norsk og svensk, hvilke tekster alle har samme gyldighed.

\section{[...]}

\section{Slutbestemmelser til overenskomsten af} den 18. marts 1993

Overenskomsten træder i kraft tredive dage efter den dag, hvor samtlige parter har givet det finske udenrigsministerium meddelelse om deres godkendelse af overenskomsten.

Det finske udenrigsministerium underretter de øvrige parter om modtagelsen af disse meddelelser og om tidspunktet for overenskomstens ikrafttrædelse.

Originalteksten til denne overenskomst deponeres i det finske udenrigsministerium, der tilstiller de øvrige parter bekræftede genparter heraf.

Til bekræftelse heraf har undertegnede befuldmægtigede repræsentanter undertegnet denne overenskomst.

Udfærdiget i Helsingfors den 18. marts 1993 i et eksemplar på dansk, finsk, islandsk, norsk og svensk, hvilke tekster alle har samme gyldighed.

[...]

\section{Slutbestemmelser til overenskomsten af den 29. september 1995}

Overenskomsten træder i kraft femten dage efter den dag, da samtlige parter har givet det finske udenrigsministerium meddelelse om deres godkendelse af overenskomsten.

Det finske udenrigsministerium underretter de øvrige parter om modtagelsen af disse meddelelser og om tidspunktet for overenskomstens ikrafttrædelse.

Originalteksten til denne overenskomst deponeres i det finske udenrigsministerium, som tilstiller de øvrige parter bekræftede genparter deraf. 
Til bekræftelse heraf har undertegnede befuldmægtigede repræsentanter undertegnet denne overenskomst.

Udfærdiget i København den 29. september 1995 i ét eksemplar på dansk, finsk, islandsk, norsk og svensk, hvilke tekster alle har samme gyldighed.

[...]

\section{Liste over fodnoter}

1 Ny ordlyd 1974.

2 Ny ordlyd 1983.

3 Artiklen indsat 1974.

4 Ny ordlyd 1971.

5 Artiklen indsat 1971.

6 Ny ordlyd 1985.

7 Ny ordlyd 1991.

8 Ny ordlyd 1993.

9 Ny ordlyd 1995. 


\section{The Helsinki Treaty}

Treaty of Co-operation between Denmark, Finland, Iceland, Norway and Sweden

(the Helsinki Treaty).

This Treaty was signed on 23 March 1962 and entered into force on 1 July 1962. The original text has been amended by Agreements that were signed on 13 February 1971, 11 March 1974, 15 June 1983, 6 May 1985, 21 August 1991, 18 March 1993, and 29 September 1995. The most recent amendments entered into force on 2 January 1996.

\section{Preamble to the Treaty of}

\section{March 1962}

The Governments of Denmark, Finland, Iceland, Norway and Sweden, desiring to promote and strengthen the close ties existing between the Nordic peoples in matters of culture, and of legal and social philosophy, and to extend the scale of cooperation between the Nordic countries;

desiring to attain uniformity of regulation throughout the Nordic countries in as many respects as possible;

desiring to achieve, where possible, an appropriate division of labour between the Nordic countries in all those fields; and desiring to continue the co-operative efforts of significance to the Nordic countries that take place within the Nordic Council and other co-operative agencies,

have agreed to the following provisions:

\section{Preamble to the Agreement of}

\section{February 1971}

The Governments of Denmark, Finland, Iceland, Norway and Sweden, desiring to strengthen and expand the institutional foundations for co-operation between the Nordic countries;

considering it appropriate for this purpose to amend the Treaty of Cooperation of 23 March 1962 between the Nordic countries;

having resolved therefore to include in the Treaty of Co-operation the fundamental provisions regarding the Nordic Council; and

having resolved further to include in the Treaty of Co-operation provisions regarding a Nordic Council of Ministers, with competence in the whole field of Nordic co-operation,

have agreed as follows:

\section{Preamble to the Agreement of}

\section{March 1974}

The Governments of Denmark, Finland, Iceland, Norway and Sweden,

having amended the Treaty of Cooperation between the Nordic countries of 23 March 1962 by the Agreement of 13 February 1971; and considering it appropriate to make certain further amendments and additions to the Treaty,

have agreed as follows:

\section{Preamble to the Agreement of}

\section{June 1983}

The Governments of Denmark, Finland, Iceland, Norway and Sweden,

having amended the Treaty of Cooperation between the Nordic countries of 23 March 1962 by the Agreements of 13 February 1971 and of 11 March 1974; and considering it appropriate to make certain amendments to the Treaty in order to provide the Faeroe Islands and the Åland Islands with 
a greater measure of representation on the Nordic Council and on the Nordic Council of Ministers, as well as to give Greenland the same measure of representation on these bodies, have agreed as follows:

\section{Preamble to the Agreement of 6 May 1985 \\ The Governments of Denmark, Finland, Iceland, Norway and Sweden, having amended the Treaty of Co- operation between the Nordic countries of 23 March 1962 by the Agreements of 13 February 1971, of 11 March 1974 and of 15 June 1983; and \\ wishing to make more effective the workings of co-operation between the Nordic countries, \\ have agreed as follows:}

\section{Preamble to the Agreement of}

\section{August 1991}

The Governments of Denmark, Finland, Iceland, Norway and Sweden,

having amended the Treaty of Cooperation between the Nordic countries of 23 March 1962 by the Agreements of 13 February 1971, of 11 March 1974, of 15 June 1983 and of 6 May 1985; and

considering it appropriate to make certain amendments to the organisation and working methods of the Nordic Council,

have agreed as follows:

\section{Preamble to the Agreement of}

\section{March 1993}

The Governments of Denmark, Finland, Iceland, Norway and Sweden, having amended the Treaty of Cooperation between the Nordic countries of 23 March 1962 by the Agreements of 13 February 1971, of 11 March 1974, of 15 June 1983, of 6 May 1985 and of 21 August 1991; and

wishing to renew and expand cooperation between the Nordic countries in the light of the greater participation by the
Nordic countries in the process of European co-operation,

have agreed as follows:

\section{Preamble to the Agreement of 29 September 1995}

The Governments of Denmark, Finland, Iceland, Norway and Sweden,

having amended the Treaty of Cooperation between the Nordic countries of 23 March 1962 by the Agreements of 13 February 1971, of 11 March 1974, of 15 June 1983, of 6 May 1985, of 21 August 1991, and of 18 March 1993; and

wishing further to renew and expand co-operation between the Nordic countries in the light of the greater participation by the Nordic countries in the process of European co-operation,

have agreed as follows:

\section{Introductory Provision}

Article $1(1,8)$

The High Contracting Parties shall endeavour to maintain and develop further cooperation between the Nordic countries in the legal, cultural, social and economic fields, as well as in those of transport and communications and environmental protection.

The High Contracting Parties should hold joint consultations on matters of common interest which are dealt with by European and other international organisations and conferences.

\section{Legal Co-operation}

\section{Article 2 (9)}

In the drafting of laws and regulations in any of the Nordic countries, citizens of all the other Nordic countries shall be treated equally with the citizens of the aforementioned country. This shall apply within all those areas falling within the jurisdiction of the Treaty of Cooperation. 
Exceptions to the first paragraph may, however, be made if a requirement of citizenship is constitutionally stipulated, or is necessary because of other international obligations or is otherwise deemed necessary for particular reasons.

\section{Article 3}

The High Contracting Parties shall endeavour to facilitate the acquisition by citizens of one Nordic country of citizenship in another Nordic country.

\section{Article 4}

The High Contracting Parties shall continue their co-operation in the field of law with the aim of attaining the greatest possible uniformity in the field of private law.

\section{Article 5}

The High Contracting Parties should seek to establish uniform rules relating to criminal offences and the penalties for such offences.

With regard to criminal offences committed in one of the Nordic countries, it shall, as far as circumstances allow, be possible to investigate and prosecute the offence in another Nordic country.

\section{Article 6}

The High Contracting Parties shall seek to achieve a co-ordination of legislation in such areas, other than the aforementioned, as are considered appropriate.

\section{Article 7}

Each High Contracting Party should endeavour to ensure the implementation of regulations to allow decisions by a court of law or other public authority in another Nordic country to be executed also in the territory of the said Party.

\section{Cultural Co-operation}

\section{Article 8 (2)}

Educational provision in the schools of each of the Nordic countries shall include an appropriate measure of instruction in the languages, cultures and general social conditions of the other Nordic countries, including the Faeroe Islands, Greenland and the Åland Islands.

\section{Article 9}

Each High Contracting Party should maintain and extend the range of opportunities for students from other Nordic countries to pursue courses of study and sit examinations at its educational establishments. A student should be permitted to count part of an examination passed in one Nordic country towards a final examination taken in another Nordic country, whenever it is realistic.

It should be possible for students to receive financial assistance from their home countries, irrespective of the country in which their studies are being pursued.

\section{Article 10}

The High Contracting Parties should coordinate that part of the public education system that provides qualifications for certain occupations and professions.

The qualifications provided by such education should, as far as possible, be recognised and accepted in all the Nordic countries. Requirements relating to supplementary education and training necessitated by national conditions may, however, be prescribed.

\section{Article 11}

In those areas where co-operation is appropriate, the expansion of educational establishments should be co-ordinated through a continuous process of co-operation with regard to the planning and execution of such expansion. 


\section{Article 12}

Co-operation in the field of research should be so organised that research grants and other resources are co-ordinated and used in the best possible way, including the establishment of joint institutions.

\section{Article 13}

In order to support and strengthen cultural development, the High Contracting Parties shall promote free Nordic adult education and exchanges between the Nordic countries in the fields of literature, art, music, theatre, film and other areas of culture, and in so doing, utilise the opportunities provided by radio and television.

\section{Social Co-operation}

\section{Article 14}

The High Contracting Parties shall seek to preserve and develop further the common Nordic labour market in accordance with the guidelines drawn up in previous Agreements. Employment services and vocational guidance shall be co-ordinated. There shall be a free exchange of trainees.

Efforts should be made to achieve a uniform application of national regulations concerning health and safety at work and similar matters.

\section{Article 15}

The High Contracting Parties shall endeavour to ensure that the citizens of each Nordic country, when resident in another Nordic country, shall, as far as possible, enjoy the same social benefits as are provided for the citizens of the country of residence.

\section{Article 16}

The High Contracting Parties shall develop further co-operation in public health, and medical care and temperance work, as well as in the care of children and young people.

\section{Article 17}

Each of the High Contracting Parties shall endeavour to ensure that safety controls of a medical, technical or similar nature are executed in such a way that the authorisation or certification of the control procedure will be recognised in the other Nordic countries.

\section{Economic Co-operation}

\section{Article 18}

In order to promote economic co-operation between the Nordic countries in various areas, the High Contracting Parties shall hold joint consultations on matters of economic policy. As part of this process, they should attend to the possibilities of co-ordinating measures aimed at equalising the effects of fluctuations in the economic cycle.

\section{Article 19}

The High Contracting Parties intend to promote, to the greatest extent possible, co-operation between their countries concerning production and investment and, in this regard, to seek to create the appropriate conditions for direct co-operation between companies in two or more Nordic countries. As part of a more extensive international process of co-operation, the High Contracting Parties should seek to achieve an appropriate division of labour between their countries in matters of production and investment.

\section{Article 20}

The High Contracting Parties shall endeavour to ensure the greatest possible freedom of movement of capital between the Nordic countries. Joint solutions shall be sought in other matters of common interest pertaining to payment and currency.

\section{Article 21}

The High Contracting Parties shall seek to consolidate previously initiated co-operative 
efforts aimed at eliminating trade barriers between the Nordic countries and strengthen and develop further such co-operation to the greatest extent possible.

\section{Article 22}

In matters of international trade policy, the High Contracting Parties shall endeavour, jointly and severally, to promote Nordic interests, and shall hold joint consultations to this end.

\section{Article 23}

The High Contracting Parties shall endeavour to bring about the co-ordination of technical and administrative customs regulations and make such simplifications of customs procedures as to facilitate transport and communications between the Nordic countries.

\section{Article 24}

The regulations governing Nordic cross-border trade shall be so formulated as to cause a minimum of inconvenience to the inhabitants of the border areas.

\section{Article 25}

When the need arises, and where the appropriate conditions obtain, for the joint economic development of adjacent areas in the territories of two or more High Contracting Parties, these Parties shall jointly endeavour to promote such development.

\section{Co-operation on Transport and Communications}

\section{Article 26}

The High Contracting Parties shall endeavour to consolidate previously initiated co-operative efforts in the field of transport and communications and seek to develop this co-operation with a view to facilitating transport and communication links and the exchange of goods between the Nordic countries and to finding appropriate solutions to any problems that may exist in this field.

\section{Article $\mathbf{2 7}$}

The construction of transport and communication links that affect the territories of two or more High Contracting Parties shall take place subject to consultations between the Parties concerned.

\section{Article 28}

The High Contracting Parties shall seek to maintain and develop further the co-operation that has made their territories into a single passport-control area. Cross-border passport controls of travellers between Nordic countries shall otherwise be co-ordinated and further simplified.

\section{Article 29}

The High Contracting Parties shall co-ordinate their efforts to improve road safety.

\section{Co-operation in the Area of Environmental Protection (3)}

Article 30 (3)

In their national legislation and in the application thereof, the High Contracting Parties shall, to the greatest extent possible, place the environmental interests of the other High Contracting Parties on an equal footing with their own.

\section{Article 31 (3)}

The High Contracting Parties shall seek to harmonise their environmental protection regulations so as to attain the greatest possible measure of agreement on standards and guidelines relating to pollution, the use of toxic substances that harm the environment, and other damaging effects on the environment.

Article 32 (3)

The High Contracting Parties shall seek to co-ordinate matters relating to the allocation of nature reserves and recreational areas, and to protective initiatives and other measures for the conservation of flora and fauna. 
Other Areas of Co-operation

Article 33 (8)

Participation by the High Contracting Parties in European and other international forms of co-operation provides excellent opportunities for collaboration for the benefit of Nordic citizens and companies. The Governments bear a particular responsibility in this regard to safeguard common interests and values.

\section{Article 34}

Public Officials in the Foreign Services of any of the High Contracting Parties who are serving outside the Nordic countries shall, to the extent that it is compatible with their duties and when no objection is lodged by the country in which they are serving, also be of assistance to citizens of the other Nordic countries, should the latter not be represented in the territory concerned.

\section{Article 35}

The High Contracting Parties should, wherever possible and appropriate, coordinate their activities concerning aid to, and co-operation with, the developing countries.

\section{Article 36}

Measures aimed at disseminating greater information about the Nordic countries and Nordic co-operation should be taken in close collaboration between the High Contracting Parties and their foreign information services. Joint approaches and arrangements may be considered where these are deemed appropriate.

\section{Article 37}

The High Contracting Parties shall endeavour to co-ordinate the various branches of their official statistics.
Special Agreements (3)

Article 38 (3)

Detailed provisions concerning co-operation in the fields here mentioned may be set out in special Agreements.

\section{The Forms of Nordic Co-operation}

\section{Article 39 (4)}

In order to implement Nordic co-operation and develop it further within the terms of this Treaty and other Agreements, the Nordic countries should hold joint consultations on a permanent basis and, where necessary, take co-ordinated measures.

\section{Article $\mathbf{4 0}(4,8)$}

Nordic co-operation shall take place in the Nordic Council, in the Nordic Council of Ministers, at the meetings of the Prime Ministers, at the meetings of the Foreign Ministers and those of other Ministers and in special co-operative bodies, as well as between the specialised public authorities of the Nordic countries.

\section{Article 41}

Provisions resulting from co-operation between two or more High Contracting Parties may not be altered by any Party, unless the other Parties are notified thereof. Notification is, however, not required in urgent cases or where the provisions concerned are of minor importance.

\section{Article 42}

Public authorities in the Nordic countries may correspond directly with one another on matters other than those which, by their nature or for other reasons, should be dealt with through the agency of their Foreign Services. 


\section{Article 43 (3)}

In matters pertaining to Nordic co-operation, the principle of public access should be observed to the greatest extent possible.

\section{The Nordic Council (5)}

\section{Article $44(5,2)$}

It is in the Nordic Council that the popularly elected assemblies of the Nordic countries and those of the Faeroe Islands, Greenland and the Alland Islands, the Governments of the Nordic countries and the Home Rule Governments of the Faeroe Islands and Greenland and the Regional Government of the Åland Islands co-operate. The Council has the power to initiate proposals and to give advice on matters pertaining to co-operation between all or some of these countries and the Faeroe Islands, Greenland, and the Åland Islands and is otherwise charged with the functions evident under this Treaty and in other Agreements.

\section{Article 45 (5)}

The Council may adopt recommendations, make other representations or issue statements of its views to one or more of the Governments of the Nordic countries or to the Council of Ministers.

\section{Article 46 (5)}

In addition to what has been specifically agreed, the Council should be given the opportunity to state its views on major issues of Nordic co-operation unless this is impracticable due to time constraints.

\section{Article $47(5,2,8)$}

The Council consists of 87 elected members, representatives of the Nordic Governments and representatives of the Home Rule Governments of the Faeroe Islands and Greenland, and the Regional Government of the Alland Islands.

The Danish Parliament appoints sixteen of the elected members, the Finnish Parliament eighteen, the Icelandic Parliament seven, the Parliaments of Norway and of Sweden twenty each, the Parliaments of the Faeroe Islands and Greenland, and the Legislative Assembly of the Åland Islands two each. Each of the popularly elected assemblies also elects a corresponding number of substitute members.

The election of members and substitute members takes place annually, and their term lasts until the next election. In the election of members, different political opinions are to be represented on the Council.

Only a member of the Assembly conducting the election may be elected a member or substitute member of the Council.

The Governments, including the Home Rule Governments of the Faeroe Islands and Greenland and the Regional Government of the Åland Islands, may appoint from among their members the number of representatives they wish to send.

\section{Article $\mathbf{4 8}(5,2,8,9)$}

The national delegation of Denmark consists of the members elected by the Danish Parliament and of the representatives appointed by the Danish Government together with the delegations of the Faeroe Islands and Greenland referred to in the following paragraph. The national delegation of Finland consists of the members elected by the Finnish Parliament and of the representatives appointed by the Finnish Government together with the delegation of the Åland Islands referred to in the following paragraph. The national delegations of the other countries consist of the members elected by the national parliament and of the representatives appointed by the Government.

The delegation of the Faeroe Islands consists of the members elected by the Parliament of the Faeroe Islands and the representatives appointed by the Home Rule Government. Greenland's delegation consists of the members elected by the Parliament of Greenland and by the representatives 
appointed by the Home Rule Government. The delegation of the Åland Islands consists of the members elected by the Legislative Assembly of the Åland Islands and by the representatives appointed by the Regional Government.

The term "delegation", as used in Article 58 , paragraph 2 , shall be understood to mean the national delegation.

\section{Article $49(5,2)$}

The representatives of the Nordic Governments, the Home Rule Governments of the Faeroe Islands and Greenland and of the Regional Government of the Åland Islands are not entitled to vote in the Council.

In matters relating to the application of Agreements between certain of the countries, only the Council members of the countries involved are entitled to vote.

\section{Article 50 (5)}

The organs of the Nordic Council are the Plenary Assembly, the Presidium and the Standing Committees.

Article $\mathbf{5 1}(5,7,9)$

The Plenary Assembly consists of all the members of the Council.

The Plenary Assembly shall hold at least one ordinary session annually. Extraordinary sessions are to be held when the Presidium so decides, or when no fewer than two Governments, or no fewer than twenty-five elected members, so request.

The powers of the Council shall be exercised by the Plenary Assembly, unless otherwise specially prescribed.

Unless the Plenary Assembly decides otherwise, its deliberations shall be public.

Article $\mathbf{5 2}(5,6,7,9)$

At its annual ordinary session, the Plenary Assembly shall appoint for a term of one calendar year a Presidium consisting of a President and the number of members specified in the Rules of Procedure of the Nordic Council.
Different political opinions shall be represented in the Presidium. Each country shall be represented in the Presidium.

Members of the Presidium shall be elected members of the Council.

The Presidium deals with the Council's current business and otherwise represents the Council to the extent set out in this Treaty and in the Council's Rules of Procedure.

The Presidency of the Council shall rotate between the Nordic countries in the manner prescribed by the Rules of Procedure of the Nordic Council.

\section{Article $\mathbf{5 3}(5,9)$}

The Plenary Assembly shall determine the number of Standing Committees and their areas of operation. The Standing Committees shall prepare matters for consideration by the Council.

Article $54(5,6,7,9)$

The Nordic Council shall be assisted in its work by a Secretariat of the Presidium.

\section{Article $\mathbf{5 5}(5,2,7,9)$}

The Governments, including the Home Rule Governments of the Faeroe Islands and of Greenland and the Regional Government of the Åland Islands, the Council of Ministers, the Council Presidium, the Standing Committees and the members are entitled to submit proposals to the Council.

\section{Article $56(5,7)$}

Recommendations may be adopted by the Plenary Assembly on the basis of the proposals submitted.

Other representations may be made by the Presidium on the basis of the proposals submitted.

Statements of views are to be made by the Plenary Assembly. When representations are made by the Presidium, there shall be a statement of views by the Presidium. 
The Presidium shall report to the Plenary Assembly on the measures it has taken, with reference to the second and third paragraph of this Article.

\section{Article $\mathbf{5 7}(5,7)$}

Elected members may submit questions to a Government or to the Council of Ministers with regard to reports or communications submitted to the Council or on any other matters pertaining to Nordic co-operation.

\section{Article $58(5,2,7)$}

Each delegation is to bear the costs of its participation in the Council.

For each financial year, the Presidium shall determine how the joint expenditure is to be apportioned among the delegations.

\section{Article 59 (5)}

The Plenary Assembly shall determine the Rules of Procedure of the Nordic Council. For decisions on the adoption of Rules of Procedure, or on amendments thereto, a two-thirds majority of the elected members of the Council is required.

\section{The Nordic Council of Ministers (5)}

\section{Article $60(5,2)$}

It is in the Nordic Council of Ministers that the Governments of the Nordic countries co-operate.

The Home Rule Governments of the Faeroe Islands and Greenland and the Regional Government of the Åland Islands take part in the work of the Council of Ministers.

The Council of Ministers makes decisions to the extent set out in this Treaty and in other Agreements between the Nordic countries. The Council of Ministers is also responsible for co-operation between the Governments of the Nordic countries and between the Governments and the Nordic Council in other matters relating to co-operation.
Article $61(5,1,2,8)$

Members of a National Government, a Home Rule Government or the Regional Government of Åland Islands may in exceptional cases be represented at a meeting by duly authorised persons. However, no fewer than three countries must be represented by Government members.

It is the Prime Ministers who are responsible for the overall co-ordination of matters of Nordic co-operation. In each country, they shall be assisted by a member of the Government (the Minister for Co-operation) and an Under-Secretary of State or government official (a member of the national Standing Committee on Nordic Co-operation).

The Presidency of the Council shall rotate between the Governments of the Nordic countries in accordance with the detailed provisions of an Agreement. It is the Presidency that is responsible for co-ordinating co-operation between the Governments of the Nordic countries and for initiating action on appropriate matters. The Presidency shall preside over the business of the Council of Ministers, at other Ministerial meetings and at the consultations of the Governments on European and other international matters at all levels.

The Council of Ministers shall be assisted in its work by Committees of Government Officials and by the Secretariat of the Council of Ministers.

\section{Article 62 (5)}

The Council of Ministers is quorate when all the Nordic countries are represented on the Council of Ministers. In respect of matters of exclusive concern to certain countries, however, only those countries need be represented.

Each country has one vote in the Council of Ministers.

The decisions of the Council of Ministers shall be unanimous. Procedural matters may, however, be settled by a simple majority of 
those voting and, in the event that the vote is tied, by the casting vote of the Presidency.

Abstentions do not constitute an impediment to a decision.

\section{Article $63(5,2,8)$}

The decisions of the Council of Ministers are binding on each country. Decisions on matters that under the constitution of any one of the countries require parliamentary approval, however, are not binding on that country until approved by its Parliament. If such approval is necessary, the Council of Ministers shall be informed thereof before making its decision. Until parliamentary approval has been obtained, no other country is bound by the decision.

Decisions made under this Treaty are binding on the Faeroe Islands, Greenland and the Åland Islands, insofar as they accede to the decision in accordance with their statutes of self-government.

Article $64(5,6,8)$

The Council of Ministers shall submit an annual report to the Nordic Council on the subject of Nordic co-operation and an account of the plans for future co-operation.

The Prime Minister of the country holding the Presidency shall report to the Nordic Council on the main features of this cooperation and on co-operation between the Governments on European and other international issues.

The Nordic Council of Ministers shall submit its proposals for budgetary dispositions to the Nordic Council for its consideration.

The Nordic Council may propose changes to the priorities made in the financial framework set out by the Council of Ministers.

Unless there are extreme circumstances not to do so, the Council of Ministers shall comply with the recommendations of the Council regarding the budget, within the financial framework as set out.

\section{Article $\mathbf{6 5}$ (5)}

Prior to each ordinary session of the Plenary Assembly of the Nordic Council, the Council of Ministers shall report to the Nordic Council on the measures taken in respect of the Council's recommendations and other representations. If a recommendation or other form of representation has been addressed to one or more Governments, such a report may be submitted instead by that Government or the Governments to which the recommendations or representations were made.

Article 66 (5)

The Council of Ministers determines its own Rules of Procedure.

\section{Article 67 (5)}

Consultations between the Governments of the Nordic countries may take place at the meetings of the Nordic ministers as well as in the Council of Ministers.

\section{Amendments to the Treaty (5)}

\section{Article 68 (5)}

The Nordic Council shall be given the opportunity to state its views before the High Contracting Parties agree any amendments to this Treaty.

\section{Concluding Articles}

Final Provisions of the Treaty of 23 March 1962

\section{Article 69}

This Treaty shall be ratified and the instruments of ratification deposited at the earliest possible date with the Ministry for Foreign Affairs in Finland.

The Treaty shall enter into force on the first day of the month immediately following the date on which the instruments of ratification of all the Parties have been deposited. 


\section{Article 70}

Should any of the High Contracting Parties wish to terminate this Treaty, written notice to this effect shall be delivered to the Finnish Government, which must immediately inform all the other High Contracting Parties thereof, and of the date when notice was received.

The termination applies only to the country giving notice, and shall take effect on the first day of the month that falls six months after the date when the Finnish Government received notice of termination.

The Treaty shall be deposited with the Ministry for Foreign Affairs in Finland, and the said Ministry shall transmit certified copies thereof to each High Contracting Party.

In witness whereof the undersigned representatives, being duly authorised thereto, have appended their signatures to this Treaty.

Done at Helsinki, in the Danish, Finnish, Icelandic, Norwegian and Swedish languages, in a single copy, each text being equally authoritative, this 23rd day of March, nineteen hundred and sixty two.

$[\ldots .$.

\section{Final Provisions of the Agreement of}

\section{February 1971}

This Agreement shall be ratified and the instruments of ratification deposited at the earliest possible date with the Ministry for Foreign Affairs in Finland.

The Agreement shall be deposited with the Ministry for Foreign Affairs in Finland and the said Ministry shall transmit certified copies thereof to each High Contracting Party.

The Agreement shall enter into force thirty days after the date on which the instruments of ratification of all the High Contracting Parties have been deposited.

In witness whereof the undersigned representatives, being duly authorised thereto, have appended their signatures to this Agreement in Copenhagen this 13th day of February 1971, in the Danish, Finnish, Icelandic, Norwegian and Swedish languages, in a single copy, each text being equally authoritative.

[...]

Final Provisions of the Agreement of 11 March 1974

This Agreement shall be ratified and the instruments of ratification deposited at the earliest possible date with the Ministry for Foreign Affairs in Finland.

The Agreement shall be deposited with the Ministry for Foreign Affairs in Finland, and the said Ministry shall transmit certified copies thereof to each High Contracting Party.

The Agreement shall enter into force thirty days after the date on which the instruments of ratification of all the High Contracting Parties have been deposited.

In witness whereof the undersigned representatives, being duly authorised thereto, have appended their signatures to this Agreement in Copenhagen this 11th day of March 1974, in the Danish, Finnish, Icelandic, Norwegian and Swedish languages, in a single copy, each text being equally authoritative.

[...]

\section{Final Provisions of the Agreement of}

\section{June 1983}

This Agreement shall be ratified and the instruments of ratification deposited at the earliest possible date with the Ministry for Foreign Affairs in Finland, and the said Ministry shall transmit certified copies thereof to the other High Contracting Parties.

The Agreement shall enter into force thirty days after the date on which the instruments of ratification of all the High Contracting Parties have been deposited.

In witness whereof the undersigned representatives, being duly authorised 
thereto, have appended their signatures to this Agreement in Reykjavík this 15th day of June 1983, in the Danish, Finnish, Icelandic, Norwegian and Swedish languages, in a single copy, each text being equally authoritative. $[\ldots]$

Final Provisions of the Agreement of 6 May 1985

This Agreement enters into force thirty days after the date on which all the High Contracting Parties have notified the Ministry for Foreign Affairs in Finland that the measures necessary for the Agreement to enter into force have been taken.

The Ministry of Foreign Affairs in Finland shall notify the other High Contracting Parties of the time of receipt of these notifications.

The original text of this Agreement shall be deposited with the Ministry of Foreign Affairs in Finland, which shall transmit certified copies thereof to the other High Contracting Parties.

In witness whereof the undersigned representatives, being duly authorised thereto, have appended their signatures to this Agreement.

Done at Lund this 6th day of May 1985, in the Danish, Finnish, Icelandic, Norwegian and Swedish languages, in a single copy, each text being equally authoritative.

\section{$[\ldots]$}

Final Provisions of the Agreement of 21 August 1991

This Agreement enters into force thirty days after the date on which all the High Contracting Parties have notified the Ministry for Foreign Affairs in Finland that the Agreement has been approved.

The Ministry of Foreign Affairs in Finland shall notify the other High Contracting Parties of the receipt of these notifications and of the date of entry into force of this Agreement.

The original copy of this Agreement shall be deposited at the Ministry of Foreign Affairs in Finland, which shall transmit certified copies thereof to the other Parties.

In witness whereof the undersigned representatives, being duly authorised thereto, have appended their signatures to this Agreement.

Done at Tampere, this 21st day of August 1991, in the Danish, Finnish, Icelandic, Norwegian and Swedish languages, in a single copy, each text being equally authoritative.

$[\ldots]$

\section{Final Provisions of the Agreement of}

\section{March 1993}

This Agreement enters into force thirty days after the date on which all the High Contracting Parties have notified the Ministry for Foreign Affairs in Finland that the Agreement has been approved.

The Ministry of Foreign Affairs in Finland shall notify the other High Contracting Parties of the receipt of these notifications and of the date of the entry into force of this Agreement.

The original copy of this Agreement shall be deposited at the Ministry of Foreign Affairs in Finland, which shall transmit certified copies thereof to the other High Contracting Parties.

In witness whereof the undersigned representatives, being duly authorised thereto, have appended their signatures to this Agreement.

Done at Helsinki, this 18th day of March 1993, in the Danish, Finnish, Icelandic, Norwegian and Swedish languages, in a single copy, each text being equally authoritative.

[...]

\section{Final Provisions of the Agreement of}

\section{September 1995}

This Agreement enters into force fifteen days after the date on which all the Parties have notified the Ministry for Foreign Affairs in Finland that the Agreement has been approved. 
The Ministry of Foreign Affairs in Finland shall notify the other Parties of the receipt of these notifications and of the date of entry into force of this Agreement.

The original copy of this Agreement shall be deposited at the Ministry of Foreign Affairs in Finland, which shall transmit certified copies thereof to the other Parties.

In witness whereof the undersigned representatives, being duly authorised thereto, have appended their signatures to this Agreement.

Done at Copenhagen this 29th day of September 1995, in the Danish, Finnish, Icelandic, Norwegian and Swedish languages, in a single copy, each text being equally authoritative.

[...]

\section{List of footnotes}

1 New wording in 1974.

2 New wording in 1983.

3 This article was added in 1974.

4 New wording in 1971.

5 This article was added in 1971.

6 New wording in 1985.

7 New wording in 1991.

8 New wording in 1993.

9 New wording in 1995. 


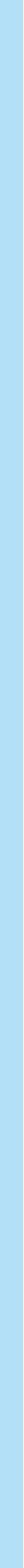




\section{$\mathbb{1}$}

Nordiska ministerrådet

Nordens Hus

Ved Stranden 18

DK-1061 Köpenhamn K

www.norden.org

ANP 2018:717

ISBN 978-92-893-5364-9 (PRINT)

ISBN 978-92-893-5365-6 (PDF)

ISBN 978-92-893-5366-3 (EPUB) 